\title{
Contemporary \\ Problems \\ of Social Work
}

ACADEMIC JOURNAL

\author{
Vol. 4. No. 4 (16) \\ 2018
}




\section{CONTEMPORARY PROBLEMS OF SOCIAL WORK}

\section{Volume 4, №. 4 (16), 2018}

ISSN 2412-5466

The journal is included into the system of Russian science citation index and is available on the website: www.elibrary.ru

DOI 10.17922/2412-5466-2018-4-4

\section{CHIEF EDITOR}

Maloletko A.N.

doctor of economic sciences, professor, vice-rector for research, Russian State Social University, Russia

\section{DEPUTY EDITOR}

Kaurova 0.V.

doctor of economic sciences, professor, dean of the faculty of training of scientific and scientific-pedagogical personnel, Russian State Social University, Russia

\section{EDITORIAL BOARD}

Feber J. (PhD, University of Trnava, Slovakia) Mirsky J. (PhD, Ben-Gurion University
of the Negev, Israel)

Moore Alan Thomas (Bachelor of Arts (Hons), M.A., leading to the Capital FM 105.3, Ireland)

NV Nikiporets-Takigawa G.Yu. (PhD, professor, University of Cambridge, UK)

Petrucijová J. (PhD, University of Ostrava, Czech Republic)

- Roer-Strier D. (PhD, Hebrew

University of Jerusalem, Israel)

Santiesteban Perez M. (PhD,

University of Guantanamo, Cuba)

Turdubaev S.K. (doctor of economic sciences, associate professor, director of Russian State Social University in Osh, Kyrgyz Republic)

Turro Breff A. (PhD, University of

Guantanamo, Cuba)

Vietze D. (PhD, The City University of New York, USA)

Vietze P. (PhD, Montclair State University, USA)

Badmatsyrenov T.B. (candidate of sociology sciences, associate professor, Buryat State University, Buryatia, Russia)

Chernikova L.I. (doctor of economic sciences, associate professor, Financial University under the Government of the Russian Federation, Russia)

\section{N T $\mathbb{E}$ N T S}

ECONOMY

Aleksandrov Yu.N., Vorobeva T.I., Maloletko N.E.

The Cryptocurrency in the Russian

Criminal Environment. .................4

PEDAGOGY

\section{Moore Alan Thomas}

Creating Awesome: Transition from College

to International Institution (Part 1) . . . . . . . . . 10

\section{SOCIOLOGY}

\section{Altaibaatar Jargal}

Buddhist Religious Non-Governmental

Organizations in Mongolia . . . . . . . . . . . . . 18

Kozhanova V.P., Bagrova N.V., Papkova N.E.

Social Consequences of the Center-Periphery

Migration of the Population in Russia . . . . . . . . .27

\section{PSYCHOLOGY}

Bagrova N.V., Papkova N.E.

Socio-Psychological Peculiarities of Creative

Activity and Creativity in Old Age and

Development Program of the Capital City

for Older People ......................37

Papkova N.E.

Problems of «Sandwich» Generation:

Psychological and Gender Aspects . . . . . . . . . . . .46

\section{LABOUR PROTECTION}

Nakhapetyan A.A., Erokhova V.V.

Analysis of the Dynamics of Changes

in the Elemental Composition of Ecosystems

Under the Influence of Anthropogenic

Activities.......................53

\section{SPECIAL COLUMN}

Delis Sevila Rodríguez, Alberto Turro Breff,

Jorge Olivares Boada

METODOLOGÍA PARA LA GESTIÓN

UNIVERSITARIA CON ENFOQUE PROSPECTIVO

EN LA INTEGRACIÓN DE LA EDUCACIÓN

SUPERIOR EN GUANTÁNAMO . . . . . . . . . . . . . .59

Methodology for University Management

with Prospective Approach in the Integration

of Higher Education in Guantánamo. . . . . . . . . . . . .59 
Delis Sevila Rodríguez,

José Antonio Rodríguez Oruña,

Alberto Turro Breff

METODOLOGÍA PARA LA GESTIÓN POR

COMPETENCIAS

HACIA EL DESARROLLO LOCAL EN LOS CENTROS

UNIVERSITARIOS MUNICIPALES DE GUANTÁNAMO . . . .70

Methodology for the Management

By Competences Towards the Local Development

in the Municipal University Centers of Guantánamo. . . .70

Gener Chang Jorge, Yaritza Martínez Adams

VALOR DIDÁCTICO DE LAS PRÁCTICAS

DE CAMPO EN LA ENSEÑANZA INTEGRADORA

DE LAS CIENCIAS NATURALES . . . . . . . . . . . . .78

Didactic Value of the Farm Practices in the

Integrative Teaching of the Natural Sciences. . . . . . . .78

Maribel Santiesteban Pérez,

Roger David Desten Santiesteban

CAMBIOS ESTRUCTURALES EN LA FAMILIA

ACTUAL. COMPENDIO REFLEXIVOS . . . . . . . . . . . . . .84

Structural Changes in the Current Family.

Reflexive Compendium .................84

Rafael Jorge Hechavarria, Jesús Piclín Minot,

Elena Bailey Agramonte

PROCEDIMIENTOS PARA FAVORECER

LA IDENTIDAD CULTURAL LOCAL EN EL

CONTEXTO DE LA FORMACIÓN

DEL PROFESOR DE GEOGRAFÍA . . . . . . . . . . . . . . .87

Procedures to Promote Local Cultural Identity

in the Context of the Geography Teacher Training . . . . .87

Yaritza Martínez Adams, Gener Chang Jorge

LA INTEGRIDAD BIOLÓGICA DEL ORGANISMO

HUMANO EN EL CONTEXTO DE TRABAJO

DE CAMPO .......................994

The Biological Integrity of the Human Organism

in the Context of Field Work. . . . . . . . . . . . . . .94

๑ Russian State Social University
Dusenko S.V. (doctor of sociological sciences, associate professor,

Russian State University of Physical Education, Sport, Youth and Tourism (SCOLIPE), Russia)

Frolova E.V. (doctor of sociological sciences, associate professor, Russian State Social University, Russia)

Rostovskaya T.K. (doctor of sociological sciences, professor, Institute of Social and Political Studies of the Russian Academy of Sciences (ISPR RAS), Russia)

Sizikova V.V. (doctor of pedagogical sciences, professor, Russian State Social University, Russia)

Vinogradova M.V. (doctor of economic sciences, associate professor, Russian State University of Tourism and Service, Russia)

Vishnyakova V.A. (candidate of economic sciences, Russian State Social University, Russia)

\section{EXECUTIVE SECRETARY}

Vishnyakova V.A.

candidate of economic sciences,

head of department scientific and

technical information RSSU

\section{WORKED}

Contenting

Papkova N.E.

Chief editor of quick printing

Bagrova N.V.

Typesetting and design

Probilova T.A.

Decorating

Probilova T.A.

Cover design

Veselovskaya M.M.

Our address:

129226, Moscow, Wilhelm Pieck street, 4, building 2, room 410, 412

Contact phone:

8 (495) 255-67-67

(ext. 17-63, 17-71, 17-80).

http://rgsu.net/about/science/

publishing/magazine/

E-mail: editorialofficeRGSU@yandex.ru

The materials are published in author's edition. Authors of published materials are responsible for the selection and the accuracy of facts, quotations, proper names, statistics and other information. Editorial opinion may not coincide with the opinion of the authors of the articles. Reprint of materials and use them in any form, including electronic media, possible only with written permission of editorial office.

Age limit: $16+$ 


\title{
ECONOMY
}

\section{Aleksandrov Yu.N.,}

Deputy Head of Department of Computer Science and Mathematics of Kikot Moscow University of the Ministry of the Interior of Russia, Moscow.

E-mail: ayn1972@yandex.ru

\section{Vorobeva T.I.,}

Senior Lecturer in Computer Science and Mathematics of Kikot

Moscow University of the Ministry of the Interior of Russia, Moscow.

E-mail: tiv1007@rambler.ru

\section{Maloletko N.E.,}

Candidate of Economic Science, Senior Lecturer in Computer

Science and Mathematics of Kikot Moscow University of the Ministry

of the Interior of Russia, Moscow.

E-mail:1102505@mail.ru

Scopus Author ID: 57191744503

\section{The Cryptocurrency in the Russian Criminal Environment}

\author{
Receiving date: \\ Preprint date: \\ 10.09.2018 \\ 19.11.2018 \\ Taking to print date: \\ 18.12.2018
}

Annotation: the authors believe that the use of cryptocurrency by Russian criminals will become an integral part of the future. The authors note that there is interest in cryptocurrency from the side of researchers. This is evidenced by the number of reports of interest at the annual conference (FC). On the other hand, the criminal environment is also becoming intellectually developed. The Russian criminal environment is pleased that nothing can restrict the operations, even the imposition of sanctions.

Key words: cryptocurrency, criminal, environment, future, police officers.

JEL classification: $A 100, A 110, A 130$.

\section{Introduction}

Cybercrime is a crime in the field of information technology committed by people using these technologies for criminal purposes [1]. The fight against cybercrime is becoming one of the global problems due to the ever-improving and expanding spectrum of information technologies of globalization, information and communication technologies and the emergence of international computer networks [4]. The increase in users who connect to the Internet, any information and technical innovations increase the possibility of committing financial crimes. 
J. Bonneau, A. Miller, J. Clark, A. Narayanan, J. Kroll \& E. Felten point out that it promises to be a growing literature has identified hidden-but-important properties of the system, discovered attacks, proposed promising alternatives, and singled out difficult future challenges [2].

0 . Marian considers that cryptocurrencies possess all the traditional characteristics that tax haves do. He say that earnings are not subject to taxation, and taxpayers' anonymity is maintained. The operation of cryptocurrencies, however, is not dependent on the existence of financial intermediaries. Thus, cryptocurrencies have the potential of defeating the recent successes of governments in battling offshore tax evasion [11].

\section{Methods}

The authors turned their attention to crimes using crypto currency. Cryptocurrency is a digital currency protected by cryptographic technologies [3]. New monetary units arise as a result of the execution of a specific computer program. Mining is the process of executing such a program, which leads to the emergence of a cryptocurrency, the creation of its new blocks [15]. It is need to generate a cryptographic signature for For the appearance of the next block. The output is new bitcoins. Any cryptocurrency is not tied to the emission center and is used in a user distributed network, that is, it is decentralized. Also, this currency does not have a binding to a specific person, in this case there is such a property as anonymity. The cryptocurrency software base is based on open bitcoin code. This currency has no physical counterpart, it exists only in the virtual space [13].

The authors note that initially the single-miners coped independently with the creation of blocks. With the complexity of the mining process, more powerful computing power was required. Therefore, the miners pooled and mined new bitcoins together.

The authors note that there is interest in cryptocurrency from the side of researchers [5]. This is evidenced by the number of reports of interest at the annual International Conference on Financial Cryptography and Data Security (Fig. 1).

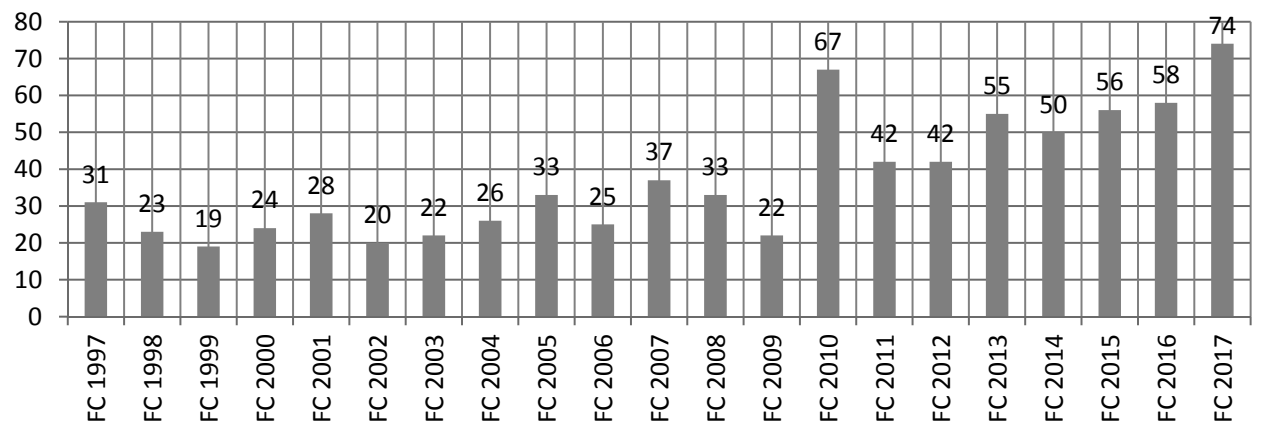

Source: https://link.springer.com/conference/fc

Figure 1. The number of reports on FC from 1997 to 2017

\section{Results}

Russian criminals are attracted to some of the advantages of cryptocurrency [9]. Russian criminals are attracted by the fact that to get started they only need access to the Internet [7, p. 4]. There is no age or any other restrictions, as well as complex registration. Indeed, to get started, they need to download the program to computer or smartphone, which generate the web wallet address.

Despite the high price volatility due to the free market, fluctuations in the exchange rate of the cryptocurrency can be much less than the fall in the rates of national currencies when political instability occurs in the state, or even a default is declared. Therefore, the Russian criminal environment is pleased that nothing can restrict the operations, even the imposition of sanctions. 
For the criminal environment, it is important that transactions can be made at any time of the day, on any day of the week.

The ability of instant transfers is the most important advantage of cryptocurrency for the criminal environment. Cryptocurrency transactions are instantaneous, while bank transfers take 4-5 business days. But when transferring large amounts, it is need to wait for a few confirmations by the transaction network, which takes no more than an hour.

Another clear advantage for the criminal environment is that the Number of wallets and addresses is unlimited. Only the owner of the wallets and addresses is the owner of his money.

Blockchain provides easy reception and sending of donations. To get donations, crimes can just publish bitcoin address. At the same time, they can be sent targeted, which guarantees the impossibility of the influence of law enforcement agencies on the conduct of the transaction.

On the other hand, it is also important for criminals that it is possible to link a transaction to specific people or organizations of certain addresses to control financial transactions.

The transferred amounts are practically not charged to the commission, often and generally free of charge, and also do not depend on the location of the parties. The commission is required only when generating technically large transactions that load the network, or, conversely, very small amounts to avoid spam attacks on the network by huge number of meaningless transactions. There are no subscription fees, limits and other restrictions.

Cryptocurrencies have another advantage, which is significant for the Russian criminal environment. Cryptocurrencies allow to exercise full control over own funds.

Indeed, the offender cannot manage the property of the victim without her consent. It is prosecuted. But, as soon as the victim sold her property, that is, exchanged it for money, the new rules come into play. Now anyone can manage the money of the victim. You can manage the money of the victim legally. Using banks. After all, information about money in the account is nothing more than a record that the bank owes them. But the owner of the money can no longer control them.

Blocking the bank account of the owner, even if the owner is a criminal, revoking transactions, even if it is illegal transactions, and managing other people's funds, even if there is a legal owner, becomes impossible if it concerns cryptocurrency.

\section{Discussion}

Cryptocurrencies have disadvantages from the standpoint of the criminal environment.

First, the blockchain performs only the installed functions, which can be seen by anyone, since the source codes are open and available for study. Decentralized release, in addition to the possibility of extracting money to everyone, causes the lack of control over this process.

Secondly, smart contracts, multi-signatures prevent illegal operations and become convenient for business and users. A business can create transactions with a guarantor when, for example, two out of three signatures are required to complete a transaction. Smart contracts allow you to set much more complex conditions for performing operations.

Thirdly, the cryptocurrency is protected by a unique code such as an electronic signature. Therefore it is copy-protected, and therefore it cannot be faked.

The use of cryptocurrency in the criminal environment is affected by factors of fluctuations in the rate, low confidence in cryptocurrency, high risks of losing cryptocurrency, hacker attacks of other criminal communities, possible exchange bakrotstvo, lack of cryptocurrency.

The use of cryptocurrency in the criminal environment is affected by factors of fluctuation of the rate, low confidence in cryptocurrency, high risks of losing cryptocurrency, hacker attacks of other criminal communities, possible bankruptcy of the exchange, the insecurity of cryptocurrency.

\section{Conclusion}

Basically, attackers use two directions of cryptocurrency turnover for criminal purposes: 
a) they use it as an instrument of criminal encroachment: they use it in the "dark" Internet as money to buy weapons, drugs, psychotropic substances and legalize the proceeds from crime.

b) they consider it as a subject of criminal encroachment and carry out the embezzlement of cryptocurrencies from the accounts through Internet fraud.

Economists and law enforcement agencies were able to study the methods of money laundering themselves and to suggest their possible use in the Russian criminal environment.

Currently known three-phase model of laundering of proceeds of crime, often used in drug trafficking. An interesting fact is that the retail trade in narcotics occurs mainly for cash, with the advantage given to small denominations.

The first phase of laundering, which is also the most risky, is called placement, that is, the transfer of cash into non-cash form. Also, sometimes criminals invest their money in various securities or assets and place them in bank accounts.

However, in most cases, attackers manage to safely complete the first stage of money laundering through corruption, by opening of multiple deposits and by other methods.

The next phase of laundering is layering. Criminals carrying out various monetary transactions in order to conceal the financial traces of real investors.

Transferring significant amounts into cryptocurrencies will immediately arouse the interest and desire to find the "entry point" of this money and find out why this citizen is trying to withdraw the supposedly honestly earned billion in such a strange way. It is at this stage that those who try to withdraw big money through cryptobirds from the attention of control bodies are caught. Especially if transactions occur regularly. So the paradox is that withdrawing big money into cryptocurrency now does not protect from attention, but causes suspicion.

The withdrawal of money in cryptocurrency does not give them legality. This is an unnecessary and unsafe phase of laundering. Cryptocurrencies themselves need a kind of 'laundering', in the sense that they need to be transformed into the usual financial instruments.

The next stage is integration, consolidation of assets of different origin and incorporation of them back into the legal economy. In most cases, money is credited to a bank account, and not just in a bank, but in a very solid bank, and preferably in some very developed country. If this succeeds, the laundering process is completed, the money is included in the legal turnover.

Thus, the key element of money laundering, that is, the legalization of proceeds from criminal activity are banks, at all stages of money laundering.

And in order to circumvent these banks, modern criminals use three main schemes.

Scheme 1: Exchange of cryptocurrency, obtained through illegal trade operations on the network, on commodity exchanges, then transferred to a prepaid card and then withdrawn at any ATM.

Scheme 2: Exchange of criminally obtained incomes on commodity exchanges, funds are transferred to a credit institution, after which they are credited to accounts of companies located on the borders of the Russian Federation, that is, offshore.

Scheme 3: With the help of an independent wallet, where people transfer virtual currency, which is subsequently returned in parts back to the sender from other individuals. It is necessary to take into account the fact that those who use one purse are not familiar with each other, and thus a break in the connection between the criminals and the criminal money is seen.

So, a cryptocurrency is a promising direction of development and investment, which has a lot of advantages over ordinary money: a quick and easy start, full control over your funds, instant transfers, low commissions, supranational systems, security, reliability, security, blockchain and others. But on the other hand, people are trying to deceive their state, using anonymity and the impossibility of tracing for the sake of profit.

Such risks can be minimized by introducing modern protection systems and effective response procedures, meeting information security requirements, raising awareness of personnel in the field of information security. The problem of 'reliable hands' is just the same or, in other words, 
qualified personnel is still one of the most pressing. It has a special relevance over the past years, because today a person remains the most vulnerable link in IT infrastructure.

\section{References}

1. Andreev A.S. Elements of Post-Criminal Behavior of Persons Connected with Criminal Activities (by the Example of Criminal Cases of Murders Investigated in the Rostov Region) // Contemporary Problems of Social Work. Vol. 1. 2015. No 1. P. 4-14.

2. Bonneau J., Miller A., Clark J., Narayanan A., Kroll J., Felten E. SoK: Research Perspectives and Challenges for Bitcoin and Cryptocurrencies // IEEE Symposium on Security and Privacy. 2015.

3. Cvetkova I. Cryptocurrencies Legal Regulation // BRICS Law Journal. Vol. 5. 2018. No. 2. P. 128-153.

4. Keyzerova J.V. Corruption as a Social Phenomenon // Contemporary Problems of Social Work. Vol. 2. 2016. No. 1 (5). P. 112-119.

5. Lansky J. Analysis of Cryptocurrencies Price Development // Acta Informatica Pragensia. 2016. No. 2. P. 118-137.

6. Maloletko A.N. How the Trends of the Service Sector in 2017 Affect the Economic and Social Security of the Individual // Contemporary Problems of Social Work. Vol. 3. 2017. No. 4 (12). P. 37-43.

7. Maloletko A.N. The Corruption in the Social Sphere and 'Traps' of New Technologies // Contemporary Problems of Social Work. 2016. Vol. 2. No. 4 (8).

8. Maloletko A.N. The Economic Security of the Some Public-Private Partnerships // Contemporary Problems of Social Work. Vol. 2. 2016. No. 2 (6). P. 44-48.

9. Maloletko A.N., Maloletko N.E. Economic Security Hospitality Industry: Using the Crypto Currency // Innovative Development of the Economy. 2014. No. 2 (19). P. 48-51.

10. Maloletko A.N., Maloletko N.E. Individual economic security: Reverse mortgaging // Actual Problems of Economics. Vol. 184. Issue 10. 2016. P. 242-250.

11. Marian 0. Are Cryptocurrencies 'Super' Tax Havens? // 112 Michigan Law Review First Impressions. 2013. No. 38.

12. Serova D.S. Social Security in the Provision of Services to the Population // Contemporary Problems of Social Work. Vol. 2. 2016. No. 2 (6). P. 73-80.

13. Steklov V.A. Judgment Concept 'Virtual Reality' Modern Science // Contemporary Problems of Social Work. Vol. 4. 2018. No. 1 (13). P. 84-90.

14. Tinyakova V.I., Maloletko A.N., Kaurova O.V., Vinogradova M.V., Larionova A.A. Model of evaluation of influence of globalization on the national stock market // Contributions to Economics. 2017. 17 May. P. 261-272.

15. Vorobeva T.I., Maloletko N.E. The Interactive Training of Future Police Officers in the Kikot Moscow University of the Ministry of the Interior of Russia // Contemporary Problems of Social Work. Vol. 1. 2015. No. 3 (3). P. 43-47.

16. Zaernyuk V.M., Snitko N.0. Cybercrime as a New Threat in the Activities of the Gold Mining Enterprises // Contemporary Problems of Social Work. Vol. 3. 2017. No. 1 (9). P. 55-62.

\section{REFERENCE TO ARTICLE}

Aleksandrov, Yu.N., Vorobeva, T.I. \& Maloletko, N.E. (2018) The Cryptocurrency in the Russian Criminal Environment, Contemporary Problems of Social Work. Vol. 4. No. 4 (16). P. 4-9. D0I: 10.17922/2412-5466-2018-4-4-4-9 (International bibliographic description).

\section{CONTACT INFORMATION:}

\section{Aleksandrov Yuriy Nikolaevich}

Deputy Head of Department of Computer Science and Mathematics

Kikot Moscow University

Ministry of the Interior of Russia

Academic Volgin, str., 12

117997 Moscow, Russian Federation

E-mail: ayn1972@yandex.ru

Vorobeva Tatiana Ivanovna

Senior Lecturer in Computer Science and Mathematics

Kikot Moscow University 
Ministry of the Interior of Russia

Academic Volgin, str., 12

117997 Moscow, Russian Federation

E-mail: tiv1007@rambler.ru

Maloletko Natalia Evgenievna

Candidate of Economic Sciences

Senior Lecturer in Computer Science and Mathematics

Kikot Moscow University

Ministry of the Interior of Russia

Academic Volgin, str., 12

117997 Moscow, Russian Federation

E-mail:1102505@mail.ru 


\title{
PEDAGOGY
}

\section{Moore Alan Thomas,}

Director of the College, Russian State Social University, Moscow.

E-mail: MurAT@rgsu.net

\section{Creating Awesome: Transition from College to International Institution (Part 1)}

\author{
Receiving date: \\ Preprint date: \\ 05.09.2018 \\ 19.11.2018 \\ Taking to print date: \\ 18.12.2018
}

Annotation: the development of Russian education institutions to the highest International level is an ongoing process. Many methods, paths and instruments are applied to both accelerate and refine this transformation. Each Institution has common and individual issues to resolve in order to attain recognition amongst International peers. This article will address the issues facing the RSSU College, the steps being taken and methodology applied.

Key words: International School, Russian State Social University (RSSU) College, Expats, Education, International Institutions, Russia, Community, Environment.

JEL classification: I200, I290.

\section{Introduction}

The Russian State Social University College (further College) is an integral part of the Russian State Social University (further RSSU) system. It provides both a pathway to Higher Level University Education as well as Russian High School qualifications. It is part of the National Middle Professional Education (further Vocational) Framework and as such should provide well trained and adapted young professionals to State and Private employers. This is bolstered by internal, and external, practical training and internships taken by students during their time at the College. Continual improvement undertaken in RSSU by the Rector, Natalia Pochinok, has swept the College forward with increased Internationalisation and quality. The College Project aims to develop the Institution into an International type and level Boarding School-College [5]. The introduction of the Englishlanguage NCC Education program (further NCC Education) was a vital component in the process of placing the College onto a more level playing field with its competition [8].

Competition is fierce in the education sector in Moscow, especially. The landscape in Russia's Capital is dotted with Institutions of varying degrees of quality which provide Internationally recognised English-language qualifications, notably IGCE A-Level (further A-level) and 
International Baccalaureate (further IB), which not alone enable students to enter directly into top foreign universities, they further improve career prospects of graduates within Russia. Internationally recognised qualifications are highly sought after by ambitious Russian families and the cost of same increases despite a large range of Institutions providing them in Moscow [9]. Each year the numbers of Russian, and ex-patriate (further expat) children attending such Institutions grows. In 2018 the competition will increase yet again with a new International organisation opening a full kindergarden (further K-12) operational base in Moscow (Brookes).

With Unique Selling Points (further USP) getting more difficult to define and offer, the challenge faced by the College to provide dual-stream education while, at the same time, move towards the goal of RSSU having an International College within its system, increases. For expat families they wish to place their children in environments as close as possible to those they know from home, yet allow their children to get a taste or experience of the local culture [1]. International schools provide this to a certain degree yet the financial instability experienced by Russia from November 2014 through 2015 saw an exodus of expats from Russia as International and Local companies were unwilling to pay salaries set against foreign currencies. In addition the benefits to children of these expat workers included fee payment at International schools. Having previously had long waiting lists of students hoping for acceptance, the exodus of expat families led to an alternative recruitment plan.

Having always relied on expats, these Institutions went to the 2 nd and 3 rd rank of waiting lists. It has been experienced by schools teaching solely through the medium of Englishlanguage towards the IB that incoming local students are far below the required level of English to immediately take examinations. Despite this apparent weakening of International schools from an educational standpoint, the numbers of locals applying continues increasing [4]. However a balance is begun to be reached where quality of learning and environment comes into conflict with a need to maintain numbers and profitability. Once simple offering A-levels or the IB represented major USPs, now a broader, inclusive environment and academic mobility is being considered far more advantageous by expat families and locals willing to invest in their children's educational futures [19]. At this point, the methodology and plan to realise the College's potential can be outlined. After extensive discussions with expat families in Moscow and Russian families whose children attend International schools in Moscow, the following USPs were identified:

- Cultural Diversity and Inclusivity (Experience);

- Academic Mobility (Parallel and Future Educational Steps);

- Internationally Recognised Qualifications (For non-Russian Institutions);

- Community (A place to call a 2nd home);

- Extracurricular activities (Sports, Arts, Theatre, Music);

- Aspirational Events and Activities (Charitable Work, Volunteerism, Forums);

- English Language (Education, Events, Environment).

In methodology I will describe how these USPs are being adapted into the College with references to projects that have already achieved success elsewhere. Our aim is to show what Awesome looks like.

\section{Methodology}

To begin the project it was important to identify weaknesses we could eliminate, minimize or turn into strengths. Once this step had been taken, an account of resources was taken along with potential areas of immediate development. Short, Medium and Long Terms plans and goals were set. A separate section named - Quick wins - was designed to lessen time in getting closer to having ou USPs ready and becoming Awesome.

To ensure that tasks and goals would be clear from the outside and easily adapted to changing circumstances, a "Monday-Someday Initial Action Plan" (further IAP) with an Action and Impact Assessment (further AIA) was put in place for the process towards our goal. 


\begin{tabular}{|c|c|c|}
\hline $\begin{array}{l}\text { Aspirational Goal: } \\
\text { Awesome is when stu- } \\
\text { dents come into our Col- } \\
\text { lege expecting the best } \\
\text { of education, social/ } \\
\text { personal development } \\
\text { and leave as successful, } \\
\text { confident and rounded } \\
\text { individuals, ready to } \\
\text { take on the World. } \\
\text { Creating a genuine } \\
\text { International College } \\
\text { which will be \#1 in Rus- } \\
\text { sia and known Globally } \\
\text { for both academic and } \\
\text { practical excellence. }\end{array}$ & $\begin{array}{l}\text { Concrete Steps: } \\
\text { 1. Opening eyes and minds - in- } \\
\text { creasing contact with foreign } \\
\text { views and practices } \\
\text { 2. Increasing the use of English } \\
\text { language through events, im- } \\
\text { proved recruitment and academic } \\
\text { mobility } \\
\text { 3. Developing dialogue between } \\
\text { students and faculty } \\
\text { 4. Developing a } 2 \text { nd home for } \\
\text { students, faculty and visitors } \\
\text { 5. Incorporating fully recognised } \\
\text { International qualifications } \\
\text { 6. Attracting children of Expats } \\
\text { and European students } \\
\text { 7. International Sporting Links }\end{array}$ & $\begin{array}{l}\text { Reasons for Steps/Goal: } \\
\text { Since our students and faculty are drawn } \\
\text { from a very wide area, and indeed differ- } \\
\text { ent cultures, faiths and languages, to cre- } \\
\text { ate a place where all can work, learn and } \\
\text { interact is vital. } \\
\text { By showing all that there is more to } \\
\text { College than simply learning within our } \\
\text { walls, gives a context to what we do on a } \\
\text { daily basis. } \\
\text { In connecting more fully the Faculty and } \\
\text { student body, there is a greater dynamic } \\
\text { for change as students will realise they } \\
\text { are stakeholders and look to support ini- } \\
\text { tiatives, or create their own. } \\
\text { Home is where the heart is and by giving } \\
\text { everyone a place to feel comfortable, free } \\
\text { and surrounded by positive energy, even } \\
\text { small events or changes have greater } \\
\text { impacts. }\end{array}$ \\
\hline
\end{tabular}

Figure 1. IAP Someday - What does Awesome look like

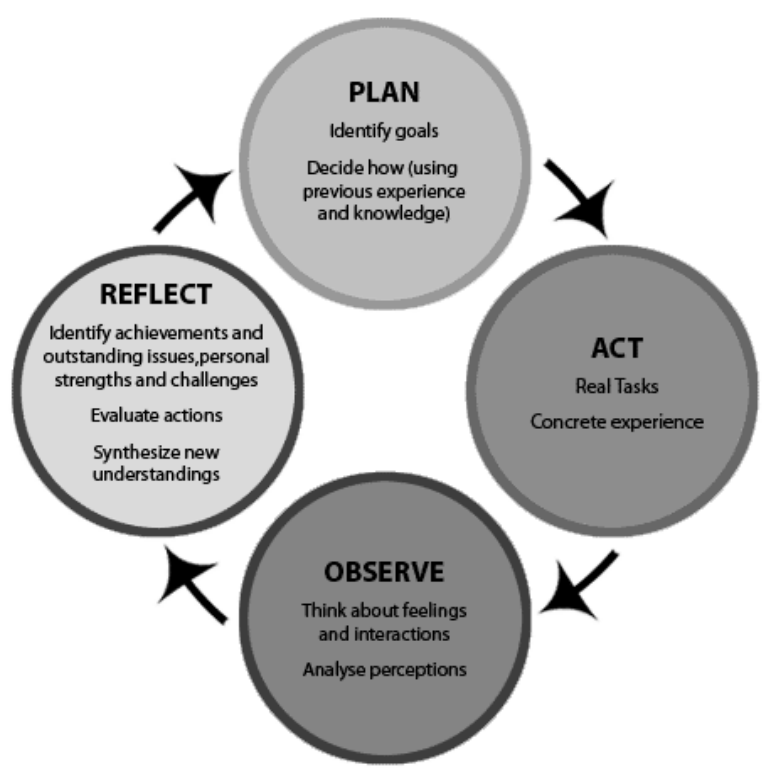

Figure 2. Simple AIA working example (Courtesy of Mira Loma High School [20])

Having both the IAP (and AIA in place at the outset allows for rapid reaction to changes in circumstances in the College, for example innovation, addition of study programs and unforeseen barriers. These instruments make the project assuredly robust, yet flexible. A path to long term, aspirational target(s) supported by short term realistic steps

Weaknesses -

Finance

Lack of Brand Awareness

International Relations 
Academic Mobility

English Language

Sports

Teaching Equipment

First Class Internationally Recognised Qualifications

Accessible Expat network

Resources -

RSSU, an entire University network

Potential Areas of Immediate Development -

Short Term

Medium Term

Long Term

Quick Wins

\section{Monday - Someday Initial Action Plan}

In the Someday IAP (fig. 1) there is an emphasis on the aspirational qualities of the project. By keeping a focus on the environment and internal culture (interaction inside faculty, between faculty - students) while developing the broader academic perspective, there is a greater chance of achieving the USP's most desired by expats - community and inclusion.

In Figure 1 attention should be drawn to column 2, Concrete Steps, and in particular point 1 Opening eyes and minds - increasing contact with foreign views and practices. In Moscow's International School community, an outward-looking, International view is a major USP. Schools possessing close relations with the network of Diplomatic missions, especially Western European Embassies, are immediately ranked higher in terms of enrollment value. Children of diplomats are more drawn to such institutions and since word of mouth is worth as much as the most expensive advertising campaign in Moscow, point 1 greatly reduces the impact of two deleterious weaknesses - finance and brand awareness.

An effective strategy related to point 1, column 2, removes completely two other weaknesses, namely International Relations and Accessible Expat Network, by building links with Embassies access to the expat community is delivered automatically.

Through sustained effort and forward planning within the purview of point 2, column 2, the English language level will improve steadily with support of faculty. Not alone will brand awareness grow, the USP's for expat families will develop organically and word of mouth will garner attention that will be sustained with regular AIA's.

Points 3 and 4, column 2, smooth the future arrival of expat students and highly motivated local students. However the problematic elements that stand as weaknesses - Sports, Teaching Equipment, Academic Mobility and First Class Internationally Recognised Qualifications require rapid resolution and are at the top of the Someday 'To do' list.

Action and Impact Assessment

A vital tool in ensuring project success is the AIA. Figure 2 presents a very simplistic representation of how it, ideally, works. To Plan an action or step it is important to have the Goal always in mind, to create an International type College. Incorporating previous experiences of company turnaround or project development then allows for the team to Act. Realising tasks to complete steps on the path to the goal can be parallel, consequential or simply unique, standalone actions. However the key point is - action.

The third part of the AIA is crucial for management to carry out professionally and consistently, Observe. There are 2 levels to this part, instinct/feeling and scientific. The first level is one purely experiential and on the human emotive. It is how, for example, students react to a meeting with foreign guests or the emotions displayed during a Christmas Carol performance. The second level, while colder, is neither less or more important than the first, it only allows for a more critical analysis of facts and figures. Observe should, ideally, position 
both levels inside the greater project plan to allow for more rapid resolutions, adjustments and future actions.

Reflect as a step is commonly confused with a debriefing, yet it is integral to the project's success. Acknowledging success, failure, analyzing factors and arriving at a common understanding of how to improve each future, and current/active, step gives the Director of the project a moment to pivot or continue.

To simplify the AIA the below example is less colourful and gives a concrete representation of an actual, completed AIA:

\begin{tabular}{|l|l|}
\hline Plan & Act \\
- English Language Carol Performance & - Begin with selection of song list \\
- Faculty Members needed & - Rehearsal schedule \\
- Required Student Profile & - Appointment of Event Manager \\
- Time, Date, Place, Equipment & - Appointment of date, time, place \\
\hline Observe & Reflect \\
\hline Monitor of song list (removal of certain num- & - Increased the emotions at end of exam session and \\
bers, addition of others) & before holidays \\
\hline Inclusion of new element (gift giving) & - Stress on participants \\
\hline - Performance: Instinct (Students and Faculty & - Deliberate non-promotion of event meant less Fac- \\
gathered in numbers joining in songs, Positive & ulty and Students in audience \\
emotions, Huge Applause, Participants in Choir & - Organic nature in the style of a flash mob allowed for \\
thrilled); Scientific (56 in audience, Perfor- & less pressure on participants and resources \\
mance lasted 20 minutes, 1 song largely sung & - Final reflection from participants very positive and \\
off key, Zero cost to College) & future events planned with lessons learned from this \\
& inaugural outing \\
\hline
\end{tabular}

Figure 3. Sample AIA - Carols at the College, December 28.12.17

In building the Action on learned experience, there was leeway given to the participants to partake in the event without undue pressure. As a first event of its type (fully English language musical performance) in the College it was of utmost importance and relevance to the aspirational goals of the IAP, the pressure needed to rest solely on the Director. With knowledge of how this would end the semester and reflect on the progress of the project to that date, a successful execution of the Carol singing session was crucial. Yet allowing it to be managed by Faculty members and involving motivated students, the image of a harmonious, all-inclusive 'family', enjoying the holiday season at home was the note on which the year needed to end.

\section{Discussion}

As stated above, the battle to win students to International Institutions is challenging and with increased market players, RSSU College is only beginning the journey the competition is experienced in.

Figure 4 outlines the challenges faced by International schools and is contemporaneous and relevant to the College experience. Save points 7 and 8, points 1 to 6 align precisely with the journey the College is on. Most interesting are the reported figures of sixty four percent $(64 \%)$ of International schools no longer visiting human resource offices of companies they are closely tied to, sixty three percent (63\%) not visiting any corporate relocation companies and a similar percentage not visiting feeder schools.

"The survey results indicate that international schools regard word-of-mouth and onsite marketing, such as referrals from current and previous families and school tours, as the most effective recruitment tools" [12].

Also contained in the 2015 report a significant role, in the recruitment process, is played by the school tour. Hence the role of International on-campus events and promotion of a positive 


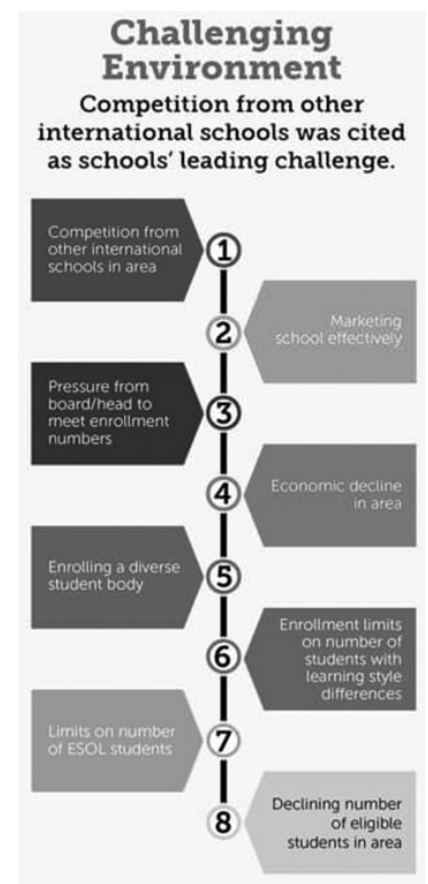

Figure 4. International School Recruitment - Challenges (Courtesy of OpenApply [11])

atmosphere is a deciding factor for many parents in choosing the education destination for their offspring.

Having previously stated the position on the 'To Do' list of 4 weaknesses - Sports, Teaching Equipment, Academic Mobility and First Class Internationally Recognised Qualifications - an immediate step was taken by the RSSU System to remedy the latter pair. Cherwell College, 0xford, was suggested as a potential academic partner to offer potential students the opportunity to study for A-Levels and also gain entry into the prestigious 0xford University. At the College level of education this is an important direction to be followed and relationship developed as attractiveness to potential students, especially expats and highly motivated locals. Having a First Class International qualification process to offer will arrive into an environment where Faculty and Students are already turning English language into a working language.

The example of a simple English language event for Faculty and Students as described in and under Figure 4 above fits into International best practice of turning language learners into language users, thus, in the College's case, creating an environment into which visits from potential students and their families is more attractive [3].

An advantage of the RSSU College for expat and highly motivated local students is the Vocational nature of education they will receive. Actual work experience, supported creativity and accessibility to student activities immediately improve the prospects for the project. The learned experience from the Russian education system and RSSU network provides vastly more opportunities for students. The RSSU Volunteer Centre gives students an outlet for volunteerism, the Student Council, known locally as StudSovet, involves students into activities and decision-making processes. Added to the existing NCC Education program and the link with Cherwell College and A-Level course, RSSU College is becoming a legitimate International Institution [6].

In relation to the Monday IAP, this is a very short-term, quick win oriented tool within the methodology to reach the stated goals. They have an immediate action and step with a far 
more rapid turnaround in the AIA cycle. A basic example below illustrates how this type of tool supports the more aspirational elements of the methodology.

\begin{tabular}{|c|c|}
\hline Action & Impact \\
\hline $\begin{array}{l}\text { Next social event - Reading } \\
\text { - Agree venue } \\
\text { - Agree format } \\
\text { - Direct Faculty to prepare students } \\
\text { - Promote event internally } \\
\text { - Cooperate with Student Council } \\
\text { - Invitation to other Faculties } \\
\text { - Organise media coverage } \\
\text { - Reception for Guest }\end{array}$ & $\begin{array}{l}\text { The event was postponed for } 1 \text { week, however the } \\
\text { impact was greater as we were better able to plan, } \\
\text { promote and involve students and other Faculties. } \\
\text { In terms of promotion of our College, it was a major } \\
\text { success. } \\
\text { Students highly engaged with the speaker. Speaker } \\
\text { use his personal social media to promote the event. } \\
\text { Students and Faculty very satisfied and motivated. }\end{array}$ \\
\hline $\begin{array}{l}\text { International day - Selecting } 1 \text { nation } \\
\text { - Agree venue } \\
\text { - Agree format } \\
\text { - Direct Faculty to prepare students } \\
\text { - Promote event internally } \\
\text { - Cooperate with Student Council } \\
\text { - Invitation to other Faculties } \\
\text { - Organise media coverage } \\
\text { - Reception for Guest } \\
\text { - Organise advance instructions with Embassy }\end{array}$ & $\begin{array}{l}\text { We selected Malaysia and were visited, } 10.11 .2017 \text {, } \\
\text { by their Tourism Attache, Mrs. Noor Zhulia Moham- } \\
\text { med. She and her assistant met with our Faculty as } \\
\text { well as students of Tourism and English. Representa- } \\
\text { tives of other Faculties attended, in addition to a } \\
\text { journalist from the Faculty of Communications Man- } \\
\text { agement of RSSU. } \\
\text { Highly informative presentation by Mrs. Noor and } \\
\text { well received by Faculty and students. Immediate } \\
\text { discussion of future academic and practical links be- } \\
\text { tween RSSU College and Malaysia. }\end{array}$ \\
\hline $\begin{array}{l}\text { Request media from our Faculty of Communica- } \\
\text { tion Management for Events } \\
\text { - Personal meeting with Dean of Faculty } \\
\text { - Appointment of liaison person from College to } \\
\text { transmit materials and plans to Faculty of Com- } \\
\text { munication Management }\end{array}$ & $\begin{array}{l}\text { Media support was requested formally, a journalist } \\
\text { attended one event. Following discussions with the } \\
\text { Faculty, we came to a working agreement that we will } \\
\text { prepare the photo and written material for publish- } \\
\text { ing, while informing the Faculty in advance of events. }\end{array}$ \\
\hline
\end{tabular}

Figure 5. Monday IAP Example November 1-14, 2017

Figure 5 above is a very simple example of how short term goals with quick wins can contribute to the overall Someday IAP.

http://www.symposium-books.co.uk/bookdetails/99/

http://www.tandfonline.com/doi/ref/10.1080/01425692.2014.971945?scroll=top

\section{Conclusion}

The RSSU College incorporated the NCC Education program in the Academic year 2016-2017 as a parallel, educational option. Now in its 2 nd year the program has started the College on the path to the ultimate goals. An agreement with Cherwell College, 0xford, is another step towards successful goal achievement. However without the complex of steps in the IAP, there will be a great many pitfalls in the way ahead.

\section{References}

1. Allen K. The international school and its community: think globally, interact locally. In: Hayden, MC, Thompson, JJ (eds) International Schools and International Education: Improving Teaching, Management and Quality. L.: Kogan Page, 2000. P. 124-139.

2. Balkhanova E.A. Information Escort of the Bachelor of Social Work in Modern Conditions of Higher Education Institution // Contemporary Problems of Social Work. Vol. 3. 2017. No. 1 (9). P. 63-68.

3. Blaj-Ward L. From language learner to language user in English-medium higher education: Language development brokers outside the language classroom // Journal of Research in International Education. 2017. Vol. 16. Is. 1 (55-64). 
4. Brummitt N. International schools: exponential growth and future implications // International Schools Journal. 2007. 27(1): 35-40.

5. Brummitt N. The Changing Face of International Schools // ISC Research Newsletter. 2010. URL: www.iscresearch.com.

6. Bunnell T., Fertig M. \& James C. What Is International about International Schools? An Institutional Legitimacy Perspective // Oxford Review of Education. Vol. 42. 2016. No. 4. P. 408-423.

7. Egorychev A.M., Mardochaev L.V., Rybakova A.I., Fomina S.N., Sizikova V.V. Society and education in the early of XXI ${ }^{\text {th }}$ century: Integration of tradition and innovation // Journal of Advanced Research in Law and Economics. Vol. 5. Issue 2.1 December 2014. P. 82-91.

8. Fail H. Teaching and Learning in International Schools // In Schooling Internationally: Globalisation, Internationalisation and the Future for International Schools / ed. by R. Bates. Abingdon: Routledge, 2013.

9. Fertig M. International School Accreditation: Between a Rock and a Hard Place? // Journal of Research in International Education. 2007. 6 (3): 333-348.10.1177/1475240907083199.

10. Gumerov M.F. Systematic Character of Secondary Vocational and Higher Economic Education in Modern Conditions // Contemporary Problems of Social Work. Vol. 3. 2017. No. 4 (12). P. 90-97.

11. Heather H. 2017. Is. 2, March. URL: https://www.openapply.com/bulletin/the-state-ofinternational-school-admission/.

12. International School Admission Industry Report. URL: https://enrollment.org/intl-admission.

13. Jesus R.C., Ricardo P.F. The Teacher and the Pedagogical Activity: Functions and Structure of the Pedagogical Activity // Contemporary Problems of Social Work. Vol. 3. 2017. No. 1 (9). P. 69-75.

14. Kazakova I.S. Sociocultural Integration in Development of Competence of Organizational and Managerial Culture in a College Student Within Higher Education Institution System // Contemporary Problems of Social Work. Vol. 3. 2017. No. 4 (12). P. 98-107.

15. Korchak E.S. Implementation of Supplementary Educational Programs into Secondary Vocational Education System // Contemporary Problems of Social Work. Vol. 3. 2017. No. 4 (12). P. 108-115.

16. Mityaeva A.M., Puzankova E.N., Egorychev A.M., Fomina S.N., Pravdyuk V.N. Interethmc communication and interaction of students in their professional training // Social Sciences (Pakistan). Vol. 11. Issue Special. Issue 3. 2016. P. 6511-6515.

17. Romanovtseva 0.V. The Competence Approach in Education // Contemporary Problems of Social Work. Vol. 2. 2016. No. 4 (8). P. 83-91.

18. Tkachenko A.V. The Culture of Interethnic Communication in Activity of Customs Service of the Russian Federation // Contemporary Problems of Social Work. Vol. 2. 2016. No. 2 (6). P. 151-158.

19. URL: http://expatchild.com/find-right-school-expat-child/.

20. URL: https://miralomacas.wordpress.com/dp-cas/what-is-cas/.

21. Varlamova E.Yu. Implementation of Ethno-Cultural Approach in Higher School As Factor of Socialization of Multilingual Person of Future Teacher // Contemporary Problems of Social Work. Vol. 3. 2017. No. 1 (9). P. 117-123.

\section{REFERENCE TO ARTICLE}

Moore Alan Thomas (2018) Creating Awesome: Transition from College to International Institution (Part 1), Contemporary Problems of Social Work. Vol. 4. No. 4 (16). P. 10-17. DOI: 10.17922/2412-5466-2018-4-4-10-17 (International bibliographic description).

\section{CONTACT INFORMATION:}

\section{Moore Alan Thomas}

Director of the College

Russian State Social University

Wilhelm Pieck str., 4, build. 1

129226 Moscow, Russian Federation

E-mail:MurAT@rgsu.net 


\title{
SOCIOLOGY
}

\section{Altaibaatar Jargal,}

Ph.D. student, Researcher of the Department of Religious Studies

of the Institute of Philosophy, Mongolian Academy of Sciences,

Ulaanbaatar, Mongolia.

E-mail: altaibaatar@gmail.com

ORCID ID: orcid.org/0000-0002-4541-0527

\section{Buddhist Religious Non-Governmental Organizations in Mongolia ${ }^{1}$}

\author{
Receiving date: \\ Preprint date: \\ 19.11.2018 \\ Taking to print date: \\ 13.09.2018 \\ 18.12.2018
}

Annotation: in this article, we present some results from the author's ongoing study on religious organizations and results of the joint project "The present state of Buddhist "social work" activities in Asia» (2016-2017), of Shukutoku University, Japan. The main challenge for every religious organization is to keep its main idea and identity, to adapt to the globalizing, sustainable developing, and rapidly changing society. The religious non-governmental organization is one of the types of adaptation of religions to the contemporary world. The article shows how Mongolian Buddhist religious non-governmental organizations are developing and adapting to the current Mongolian society.

Key words: religious organization, Buddhist religious organization, non-monastic religious organization, religious NGO, religious activities in humanitarian aid.

JEL classification: $A 140$.

\section{Introduction}

During the first twenty years of the $20^{\text {th }}$ century, Buddhism existed as a whole social institute with decisive influence and control over social life in Mongolia. In the early $20^{\text {th }}$ century, there were about 850 larger monasteries including over 100000 monks, more than 3000 small temples [22] and about 160 reincarnated (noble) lamas in Mongolia. However, interrupted by the mass repression of the 1930s in Mongolia, activities of these monasteries gradually declined, and as a result, there were left almost none by the year 1939.

1 Religious NGO (RNGO) or Faith-based NGO (FBO) - "as formal organizations whose identity and mission are self-consciously derived from the teachings of one or more religious or spiritual traditions and which operates on a non-profit, independent, voluntary basis to promote and realize collectively articulated ideas about the public good at the national or international level." - Julia Berger. Religious Non-Governmental Organizations: An Exploratory Analysis - Voluntas: International Journal of Voluntary and Non-profit Organizations. Vol. 14. No. 1 (March 2003), p. 15-39. 
But at the request of people who were monks, Gandantegchenling Monastery was allowed to reopen as "The Prayer Temple" in Ulaanbaatar by the State Conference in 1944 [6]. With the revival of Gandantegchenling monastery, Buddhist scholars and monks who were in the hiding, the sacred Buddha relics and books were gathered in the same place. The monastery, under the name "The Prayer temple", carried its activities until it regained its name Gandantegchenling in 1947 to become a central administration of Mongolian Buddhism [6].

Global changes and restructuring of Soviet Union which started in the mid-1980s resulted in the spreading of new thinking and democratic ideas in society, including religion in Mongolia. The state and the ruling party (Mongolian Peoples' Revolutionary Party) softened its strict policies on religion and became positive on believers' demands which can be evidenced by a resolution 10 of the People's Great Khural dated February 1990. By this resolution, the government allowed and was set to take measures to support to reconstruct Erdenezuu, Amarbayasgalant, and Shankh monasteries [1], which were destroyed during the Soviet era, and conduct religious activities, and formally accepted the establishment of a mosque in Bayan-Ulgii province [12]. This was an important stimulus for the revival of Buddhist organizations.

The authority had also assigned the government to take into account and provide support at the request of believers and monastic community for the reconstruction and restoration of some of the Buddhist temples and monasteries, transfer of Buddhist sutras and relics in museums and library funds those were not classified as Mongolian invaluable arts and cultural heritage. At the same time, monks were recommended to make efforts from the very beginning to develop religion while restoring monastic activities of ancient traditions in harmony with modern needs, make appropriate preparations to read and reflect religious texts in their native language, internal rules and order of priesthood discipline and to build a good reputation of religion. These served as a favorable condition for the revival of Buddhist monasteries activities.

The revival of religious freedom in the aftermath of spiritual change within Mongolian society began with initiatives by traditional Buddhist monasteries and believers and continued with religious and public institutions and Buddhist movements to intensify their activities in every branch of social life which was seen as an unprecedented phenomenon in Mongolia.

Mongolian Believers' Association established by Buddhists, had specifically focused their activities to restore traditional Buddhism, and its doctrine, to build new temples to accommodate the spiritual needs of people in local areas and revive old monasteries. As a result, the number of lay Buddhist monasteries has reached almost 100 within less than 3 years and is growing ever since which can be seen from the registration of legal entities made by State registration Authority of Mongolia.

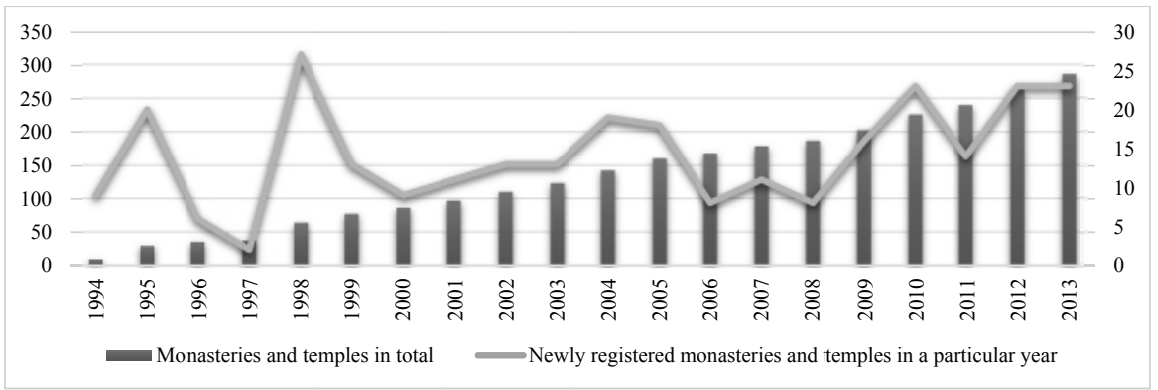

Figure 1. Number of Buddhist monasteries and temples, 1994-2013 [15]

Source: Number of religious organizations registered between 1994-2013 September by Department of Legal entity registration of the State registration Authority. Researcher's comparison.

According to the report of the Minister of Justice and Internal Affairs of Mongolia, there are 848 legal entities operating in the religious field, of which 34.6 percent accounts for 
Buddhist monasteries. As of 2016, there are 294 Buddhist monasteries operating in Mongolia. These monasteries are located throughout 22 major administrative units of Mongolia, including Ulaanbaatar city and 21 provinces. There are 107 monasteries operating in Ulaanbaatar city only, which is 36 percent of total Buddhist monasteries, albeit it makes 28.5 percent of religious organizations of all types of religion in the area. Gelugpa is the dominant school among Buddhist monasteries in Ulaanbaatar city [14].

During the first conference of Mongolian Buddhists in 1992, Gandantegchenling monastery was approved as the Center of Mongolian Buddhists. This approval ensured the free activities for the monastery to revive its datsans (monastic schools), which were closed during the repression, with the help of old monks and restore their regular religious activities [6].

With the revival of Buddhism, its behavior and norms are penetrating in all circles of activities of society and individuals. All in all, Buddhism has emerged as an independent institute of society and has sought to strengthen and expand its stances.

There are also enough ideas among lay people to receive Buddhism in terms of not only religion and customs but also of culture and knowledge.

Having survived for centuries with its deep marks in every aspect of ideology, lifestyle, culture, and customs of the Mongolian people, Buddhism, and its monasteries still play a major role in the mentality and psychology of social groups and individuals after a transitional period in Mongolia's history. This specific feature differentiates the Buddhism from other religions in Mongolia [21].

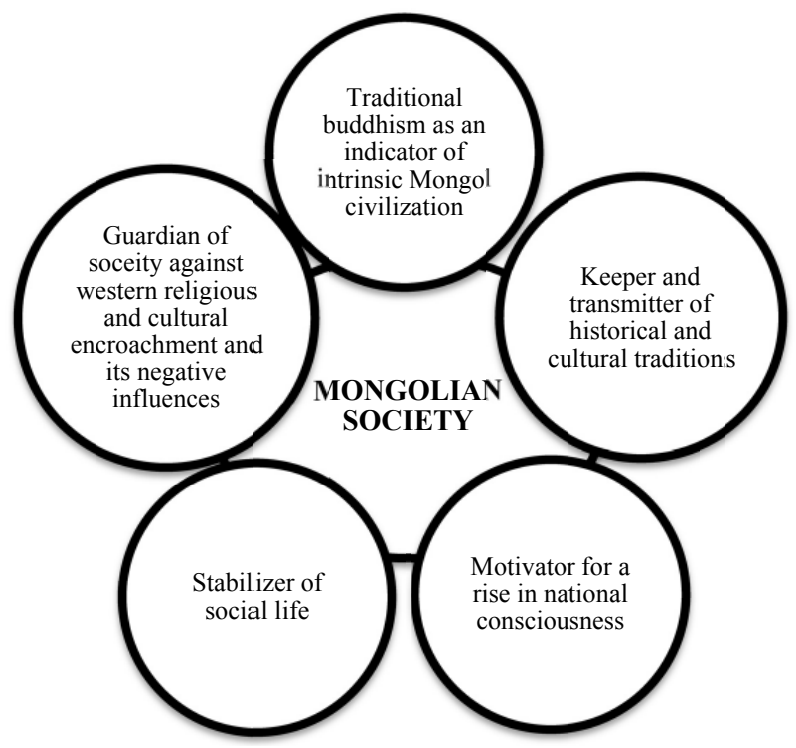

Figure 2. Social roles of Mongolian Buddhism

\section{Methodology}

After the revival of Buddhism in Mongolia, two types of religious organizations has emerged. Mongolian law on State and church relations, which has been in effect since 1993, states that religious organizations in Mongolia shall carry out religious rituals, and educational activities to meet religious demands of the devotees by establishing church, monastery, datsan, and centers [10]. Within this framework, Buddhist organizations have carried out their activities in the form of monasteries and temples. This is not new, however, from its earliest period until the end of the $20^{\text {th }}$ century, Buddhist organizations had conducted their activities in a single form of the monastery. Their activities directed at the devotees were usually found in traditional religious practices those could influence the psychology of the majority in the society. 
The main function of Buddhist monasteries is to exercise Buddhist rituals, assembly and carry out educational activities in an organizational structure of monastery, temple, datsan, and a governing body. Current organizational structure of the Buddhist temples and monasteries is a pattern established back in the second half of $16^{\text {th }}$ century to early $20^{\text {th }}$ century. Monasteries and monks serve the religious community (devotees) by creating religious texts, performing rituals and chanting [10].

At the beginning of the $21^{\text {st }}$ century, with the revival of Buddhism in Mongolia, intermediate organizations, religious but public in nature, were formed as a Religious NGO (RNG0), distinguished themselves from traditional Buddhist organizations (for example, monastery, temples, denomination etc.) by their organizational structure, management, and operational characteristics [2].

The purpose of our work is to study the social and humanitarian activities of the Buddhist religious non-governmental organizations in contemporary Mongolia.

We used the case study as the main research design. In conducting the case study, we used content analysis, focus group and standardized interviews, and observation methods were selected as the most appropriate qualitative methods for the research context.

Our research covered religious organizations, non-governmental organizations and Buddhist monasteries which registered with General Authority for State Registration of Mongolia, between 2006-2017. We have identified and selected 48 organizations as a Buddhist RNG0s from 8200 non-governmental organizations and analyzed their legal and planning documents. Data collection was conducted in two ways: main and supplementary data collecting. In the main data collecting part, content analysis, standardized and focus group interviews, and observation methods were used in order to gather general information for the case study. Meanwhile, individual in-depth interviews and expert interviews were conducted in order for explaining causes and gathering more detailed information as supplementary data collecting.

\section{Results}

When studying RNGOs, a few reasons can be identified as the cause of the formation of such organizations described in Figure 3.

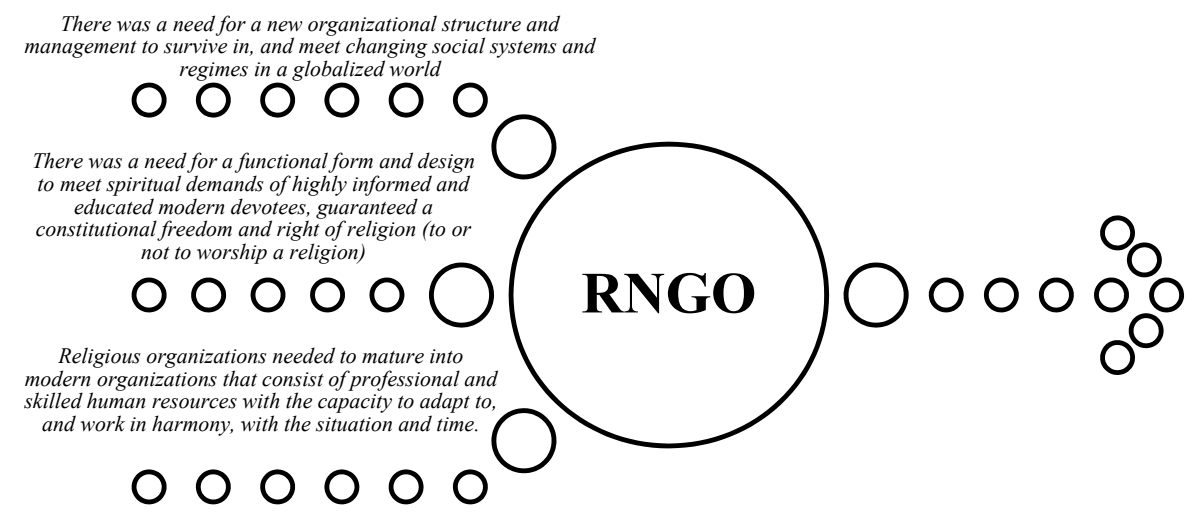

Figure 3. Cause of formation of Buddhist RNGOs

Unlike traditional monastic organizations, the main purpose of these NGOs is to disseminate and promote religious doctrines rather than engaging in religious congregations. These organizations support activities of traditional Buddhist monasteries, however, their activities are relatively independent. There is no significant difference in ranking, strict religious regime and order in the organizations and these organizations are usually managed by reputable leaders rather than professional monks. 


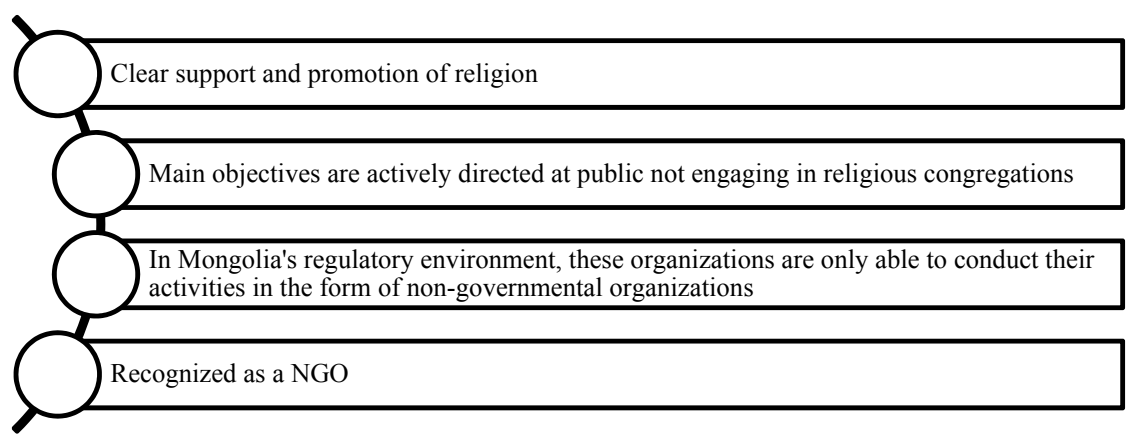

Figure 4. Main characteristics in Buddhist RNGOs ${ }^{1}$

Religious NGOs are voluntary based and are aimed mainly at supporting monasteries for disseminating and promoting religious doctrines. These organizations are independently managed from the monasteries, and financial and economic instability is common among these organizations.

From the analysis of the activities and relevant documents of religious NGOs, the mission of the organizations is commonly formulated as follows:

- to disseminate Buddhist doctrines to the public in non-traditional ways (lecture, religiousart entertaining activities etc);

- to represent the common interests of members, to build and support their cooperation, and create opportunities for the exchange of opinions and experiences;

- to organize social and humanitarian activities;

- to protect Buddhist traditions from the influences of other religious sects;

- to support the monastery in strengthening Buddhist views in the society;

Thus, Buddhist NGOs focus on disseminating Buddhist doctrines and teachings and carrying out charitable and social activities based on these views.

Table 1

\section{Comparison of contemporary Buddhist monastery vs Religious NGOs}

\begin{tabular}{|l|l|l|}
\hline \multicolumn{1}{|c|}{ Buddhist monastery } & \multicolumn{1}{|c|}{ Buddhist RNG0s } \\
ning & Strictly set, constricted & Relatively flexible, open and critical \\
\hline Human resource & $\begin{array}{l}\text { Consists of monks and priests } \\
\text { specially trained in religious } \\
\text { education }\end{array}$ & $\begin{array}{l}\text { Consists mainly of people experienced or having } \\
\text { social communications skills, not necessarily } \\
\text { trained in religious education }\end{array}$ \\
\hline Internal structure & $\begin{array}{l}\text { Comprehensive, but too complex } \\
\text { and difficult } \\
\text { Slow decision-making process at } \\
\text { the managerial level }\end{array}$ & Smaller, good coherence between units \\
\hline Form of activities & Dogmatic, doctrinal & Promotional and educational \\
\hline $\begin{array}{l}\text { Continuity of ac- } \\
\text { tivities }\end{array}$ & $\begin{array}{l}\text { Slow, but constant and con- } \\
\text { tinual }\end{array}$ & Ascending and descending \\
\hline Members & Monks & Lay people and monks \\
\hline
\end{tabular}

We have identified and selected 48 organizations as a Buddhist RNG0s from 8200 nongovernmental organizations which registered with the General Authority of State Registration

1 In some circumstances, such organizations cannot be regulated in accordance with the Mongolian law on State and church relations. In this case, these organizations must register with the General Authority of State Registration and get approval for conducting activities in accordance with Mongolian law on Non-governmental organization. 
of Mongolia between 2006 and 2017 [15]. Founders of these organizations are comprised of two types of stakeholders as follows:

1. Buddhist monks and priests with the aim to explain Buddhist teachings and doctrines and enlighten the public awareness.

2. Lay people and devotees with the aim to spread Buddhist teachings and doctrines to cultivate the meaning of compassion and humanitarian views.

of these organizations, 90 percent (or 43 RNG0) were operating in Ulaanbaatar, while only 5 organizations were operating in local provinces including 1 in Bulgan, 1 in Dornogobi, 1 in Khuvsgul and 2 in Uvurkhangai province respectively. Based on the organizational rules, functions, mission, and objectives, the scope of the social works in these organizations are as follows:

1. Practice and performance of religious rituals. The act of collective worshipping, chanting, meditating, and offering to the shrine.

2. Enlightening, building awareness and dissemination. Support building of humane and compassionate morality in individuals, families, and communities through promotion and interpretation of Buddhist teachings and scripture books.

3. Protection and conservation of nature and environment. Environmental protection and rehabilitation based on Buddhist teachings.

4. Social and humanitarian activities. Provide support for people and youth from lowincome families for education and self-development, and provide spiritual and material support for poor and homeless people.

5. Undertaking research studies. Conduct research studies in Buddhist philosophy and knowledge, write, translate and publish scriptures.

6. Restoration and protection of heritage. Restore monasteries, customs, and traditions. These activities can be ordered in terms of their importance as follows:

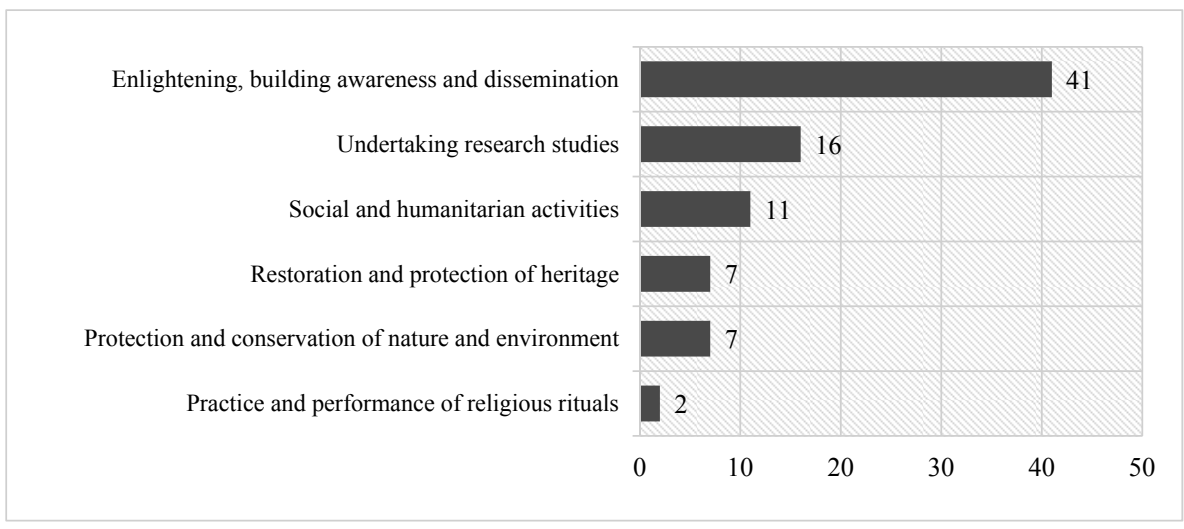

Figure 5. Types of social works carried out by Buddhist RNG0s

\section{Discussion}

Findings of the study reveal that primary purpose of Buddhist RNGOs (about 85 percent of total organizations) is to contribute to the building a humane and compassionate social environment and improve ethics and consciousness of the communities through Buddhist teachings and doctrines. Study of Buddhist philosophy is the second important purpose among these organizations. One-third of the organizations surveyed stated writing, translating (from Tibetan to the Mongolian language) of Buddhist teachings and philosophy, and literature and publishing simplified books for the lay public as the primary goal of their social activities. Of total organizations surveyed, 22 percent worked to provide aid to low income and vulnerable social groups including orphaned children, female households and single fathers to improve 
their livelihood. Religious rituals, which usually considered as the most important activities for Buddhist monasteries, accounted for the lowest percentage (only 4.1 percent).

Among these organizations surveyed, we have chosen as a case study the "Rejoice in your virtue", an RNGO that has been operating successfully for a long time.

"Rejoice in your virtue" RNG0 was founded by five members in 2001 with the aim to contribute to the community to reduce the harms resulting from people's wrong lifestyles and habits by inheriting and spreading traditional mindset and Buddhist philosophy. The RNGO has been conducting its activities continuously for sixteen years. The main focus of the organization is as follows:

- to represent common interests of its members;

- to organize local and international level events aimed at spreading buddhist doctrine to the public;

- to organize art, cultural and public events to promote mongolian cultural heritage and traditions;

- to deliver timely information relevant to buddhist doctrine, traditions, cultural heritage with the help of latest innovations in modern information technology;

- to carry out humanitarian activities aimed at supporting the livelihoods of vulnerable social groups;

- to contribute to the protection of natural environment and natural resources, restoration of valuable cultural monuments, and to promote such activities at the domestic and international level.

The organization has been regularly conducting its public activities that are well known to the Buddhist communities and lay public, including one-day "teaching-sojin" religious ceremony, production of a song "A Compassion of 21 Tara's" and its dissemination to the public, and collective chanting of religious texts/prayers in a hall or outdoor area. A number of social works have been implemented by "Rejoice in your virtue" RNGO including but not limited to:

In terms of restoration and protection of Buddhist heritage:

- Implemented restoration work of stupas in Gandantegchenling monastery, the Center of Mongolian Buddhists;

- Created a Bodi stupa in the Manzushir monastery.

In terms of enlightening of the public:

- Ran an information board to disseminate Buddhist teachings and doctrines to the public at the Gandantegchenling monastery.

- produced and distributed to the public audio tapes with Buddha's teachings, and "Enlightening doctrine" and "Chanting doctrine", prayer songs sung by famous artists.

- Organized "Enlightening" tour to spread Buddhist teachings to people in central provinces of Mongolia (Bulgan, Arkhangai, Uvurkhangai and Khuvsgul provinces).

- Produced and broadcasted a video clip of a prayer song "Rejoice in your virtue" regularly over a public television.

- Prepared and broadcasted a series of commentary program on "Altangerel" scripture on NTV television.

- Organized a book exhibition "Wisdom starts with books" of Buddhist teachings and doctrines.

In terms of religious rituals:

- Since 2004, organized religious rituals regularly, in collaboration with Gungaachoilin dastan of Gandantegchenling monastery, including "Chanting prayer", and "Sojin" i.e. one-day vowing in Visak days

The RNGO consists mainly of lay devotees with some monks at the managerial level. However, the organization operates independently of any monastery and religious figures. The organization usually carries out religious rituals on the occasions of religious days. In addition to that, the 
RNGO implements activities mainly aimed at solving particular social problems and supporting social target groups. For example, in 2016, "Your generosity is rejoiced" collaborated with two different Buddhist organizations, Great Maidar project, and Bodi Chandmani center, to initiate the Safe motherhood, a charity campaign to support the repair work of Maternity center, which is still continuing.

Majority of Buddhist RNGOs are established on a voluntary basis and lack stable financial resources. It is, therefore, common for them to collaborate with other religious organizations, monasteries, international organizations, and governmental agencies with similar organizational arrangements.

In some cases, basic operating costs are borne by Buddhist monasteries, while the majority of activities are financed by the support of collaborating business and international organizations. Moreover, some activities are financed by the certain proportion of charitable donations given by the devotees, and the profits made by business activities such as handcrafting and other manufacturing, and trading. In addition to that, the RNGO also organizes activities to find financial support from sponsors and organizations by preparing social and humanitarian projects, and fundraising through social network and public media.

Activities organized by Buddhist RNGOs are focused on following target groups.

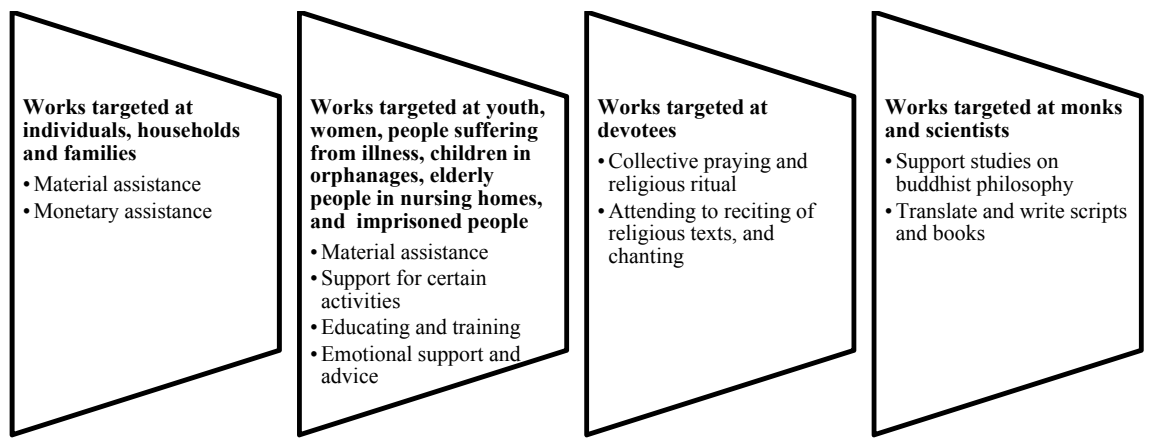

Figure 6. Target groups of activities organized by Buddhist RNGOs

Buddhist RNGOs are more actively engaged in public campaigns and impact activities than temples and monasteries do. The scope of their works includes organizing public lectures and training for improved social belief and morality, raising public awareness about the essence of Buddhist teachings and the meaning of related traditional customs, and preparing and distributing simplified programs for the lay public via media.

\section{Conclusion}

In summary, Buddhist RNGOs primarily focus their attention to bring positive changes in the spiritual lives of individuals, social groups and the society by explaining, implementing, educating, and spreading the meaning of the Buddhist doctrines, rather than taking the responsibility of religious preaching.

This type of organizations is more likely to increase in future, because, there is growing number of initiatives among the devotees to serve monastery and the society collectively by sharing and exchanging views on religious doctrines and teaching, and conducting charitable activities in addition to engaging in traditional religious practices solely under the monastic order.

\section{References}

1. Alexander B. The Situation of Buddhism in Mongolia - Study Buddhism. URL: https:// studybuddhism.com/en/advanced-studies/history-culture/buddhism-in-mongolia/thesituation-of-buddhism-in-mongolia-1994 (retrieved date: 20.04.2018).

2. Altaibaatar J. Types of religious institutions and characteristics of their activities // Academea. Mongolian Academy of Science. 2010. No. 2. (In Mongolia) 
3. Altaibaatar J. Some problems and policy solutions for realations between state and religion. Ulaanbaatar: National Development Institute, 2015. (In Mongolia)

4. Gohori J., Ogawa H. Growth of the Buddhist Social Work Activities in Mongolia. (Research series №1). Japan, Chiba: Shukutoku University, ARIISW, 2018.

5. Clarke G., Jennings M. Development, Civil Society and Faith-Based Organizations. Basingstoke: Palgrave Macmillan, 2008.

6. Divaasambuu G. Gandantegchenlin khiid dakhin sergesen tuukh (History of Revival of the Gandantegchenlin Monastery). Ulaanbaatar, 2009.

7. José Casanova. Public Religions in the Modern World. Chicago: University of Chicago Press, 1994.

8. Julia Berger. Religious Non-Governmental Organizations: An Exploratory Analysis // Voluntas: International Journal of Voluntary and Non-profit Organizations. Vol. 14. 2003. No. 1. P. 15-39.

9. Lkhanyam S., Yudina T.N. Mongolian Technical Vocational Education and Training for Enterprises // Contemporary Problems of Social Work. Vol. 3. 2017. No. 3 (11). P. 95-103.

10. Mongolian Law on State and Church Relations 1993 // Legal information system. URL: http:// www.legalinfo.mn/law/details/485.

11. Monasteries, Temples and Churches // Mongolian Statistical Information Service. 2018. URL: www.1212.mn.

12. Reconstruction and protection of some monasteries and related issues. Decree of Presidium of People's Great Khural, Mongolian People's Republic. 1990. February 22.

13. Resolution 34 of State Conference about re-open Gandantegchenling Monastery. 1944. May 25.

14. Report of the Working group set out by the Decree of the Minister of Justice and Internal Affairs. 2016. March 11.

15. Report of the Department of Legal entity registration of the State Registration Authority of Mongolia. 2015.

16. Rick James. What is Distinctive about FBOs? // INTRAC. Praxis Paper. 2009. No. 22.

17. Ronald J.S., Heidi R.U. Typology of Religious Characteristics of Social Service and Educational Organizations and Programs // Voluntary Sector Quarterly. Vol. 33. 2004. No. 1.

18. Severine D., Masooda B. Religion in Development. Rewriting the Secular Script. L.: Zed Books, 2009.

19. Stephen J. Plant. International Development and Belief in Progress // Journal of International Development. 2009. Vol. 21.

20. Tsedendamba S. Religious Situation in Mongolia. Ulaanbaatar: National University of Mongolia, 2003. (In Mongolia)

21. Tsedendamba S. The Current State of Religion in Mongolia: Some challenges. // International Conference on "Globalization and Mongolia's development". Ulaanbaatar, 2002. (In Mongolia)

22. Vesna Wallace. Surviving Modernity in Mongolia // Mongolians After Socialism: Politics, Economy, Religion / Bruce M. Knauft, Richard Taupier (Ed.). Ulaanbaatar: Admon, 2012.

23. Wendy Tyndale. Visions of Development: Faith-Based Initiatives. Ashgate, 2006.

\section{REFERENCE TO ARTICLE}

Altaibaatar Jargal (2018) Buddhist Religious Non-Governmental Organizations in Mongolia, Contemporary Problems of Social Work. Vol. 4. No. 4 (16). P. 18-26. D0I: 10.17922/24125466-2018-4-4-18-26 (International bibliographic description).

\section{CONTACT INFORMATION:}

\section{Altaibaatar Jargal}

Ph.D. student

Researcher of the Department of Religious Studies

Institute of Philosophy

Mongolian Academy of Sciences

Baruun Selbe St-15, Chingeltei district

Ulaanbaatar - 15141, Mongolia

E-mail: altaibaatar@gmail.com 


\section{Kozhanova V.P.,}

Expert of the Department of Scientific and Technical Information,

Russian State Social University, Moscow.

E-mail: vikylasor@mail.ru

Scopus Author ID: 56719572200

ORCID ID: orcid.org/0000-0003-1959-2184

口梠，回 Bagrova N.V.,

Editor in chief of Operative Polygraphy Sector of the Center for

Marketing Communication, Faculty of Communication

Management, Russian State Social University,

Moscow.

E-mail: bagrovan@bk.ru

ORCID ID: orcid.org/0000-0003-4822-5084

\section{Papkova N.E.,}

Expert of the Department of Scientific and Technical Information,

Russian State Social University, Moscow.

E-mail:marova@inbox.ru

ORCID ID: orcid.org/0000-0001-7159-086X

\section{Social Consequences of the Center-Periphery Migration of the Population in Russia}

Receiving date:

12.09.2018
Preprint date:

19.11.2018
Taking to print date:

18.12.2018

Annotation: the authors analyze the characteristics of migration processes in Russia; note mainly the Central-peripheral nature of migration; highlight the regions of Russia, giving and receiving the population; consider in detail the causes that encourage young people to migrate; presents the specific features of the youth labor market; study the negative consequences of migration, both for sending countries and for receiving. The authors note that currently migration does not provide redistribution of the population across the country in order to balance supply and demand in the labor market. Of course, it is necessary to develop mechanisms to stimulate labor migration of citizens, including through the development of the housing market and solving social problems.

Key words: migration of population, economic migration, center-periphery migration, microeconomic model of individual choice, differential mobility of population, social problems, level of wages, youth unemployment, negative consequences.

JEL classification: $A 140$.

\section{Introduction}

Migration is an eternal problem, a constant companion of natural and social transformations. The great Homer claimed: "...there is nothing worse than wandering in foreign lands". In fact, not from a good life people leave everything-home, parents, wives and children and go into the unknown.

Migration of population (lat. Migration - resettlement) - resettlement of people from one region (state, country) to another, in some cases in large groups and over long distances [4] - 
complex in nature, diverse in forms and consequences of the social process [1]. In the concept of "migration" various researchers put the most diverse meaning.

The main causes of migration are political, economic, national, environmental and religious.

There is migration in the direction (internal and external) and in time (temporary and permanent) [5].

Internal migration is particularly common in countries with a large territory, diverse climatic and economic conditions. The reasons for internal migration are job search, improvement of living conditions, improvement of living standards and changes in lifestyle, etc.

External migration - migration in which people leave their country, leaving for another. This species is very common nowadays. People believe that it is easier to live in other countries, there are no problems and everyone has a job. Meanwhile, each country has its own problems.

As a result of geographical differences in the supply and demand of labour in peacetime, economic migration is the most important.

\section{Method}

English scientist E.G. Ravenstein [13] - the author of one of the first deep theoretical studies in the field of migration (1885). After studying migration processes in the UK and North America, he formulated 11 migration laws, which were later based on many theories in the field of migration. The main ones are the following [1]:

- most migrations are carried out over short distances;

- the larger the territorial centre, the more attractive its influence is;

- each migration flow corresponds to its own counterflow;

- the growth of large cities is more driven by population migration than by natural growth;

- migration increases with the development of industry, trade and especially transport;

- the economic causes of migration are decisive [4].

Analyzing the characteristics of migration processes in Russia, it is necessary to start with internal migration, since it is the main component (almost 90\%) of the total migration turnover in Russia.

The reasons forcing Russians to move to other regions of the country are: military actions, aggravation of interethnic relations, as well as the reasons of economic nature - loss of work, non-payment of wages, and hence the decline in living standards, lack of confidence in the future, and there is a higher migration activity of rural residents in comparison with urban ones. This is due to the lower income of the rural population, which tends to the industrial areas concentrated mainly in the European part of Russia.

The direction of flows is determined by the economic characteristics of the territories: if they are attractive (from regions with low wages to regions with high wages), then there is immigration, if negative - then emigration. The signal for migration is the difference in the level of wages (income) between the territories of departure and entry. People go to other countries and regions in search of work, to places with a higher standard of living [1].

Low wages are common in sectors such as agriculture $(24.4 \%$ of those employed in the sector receive wages below the subsistence level), education $(23.7 \%)$, recreation, entertainment, culture and sports $(20.6 \%)$, and the provision of public and social services (20\%). Poverty becomes not just a phenomenon of one year, when the standard of living in the country as a whole deteriorates, it acquires the character of long-term: the work can not be changed quickly, quality education to obtain a more prestigious job requires 2-4 years, and in fact, education still needs to be earned. Raising a child with all current expenses takes 20-23 years. Thus, poverty becomes a phenomenon constantly present, dragging into the circle of poverty (table 1) [11]. Thus, according to Rosstat, the poor are mostly a family man with children, forced to work for various reasons in low-paid jobs. 
The poorest city in Russia in 2018

\begin{tabular}{|c|c|c|c|}
\hline $\begin{array}{l}\text { Place in the } \\
\text { ranking }\end{array}$ & The City & $\begin{array}{l}\text { Pov- } \\
\text { erty } \\
\text { Index } \\
\end{array}$ & Problems \\
\hline 1 place & Togliatti & 0,80 & $\begin{array}{l}\text { more than } 60 \% \text { of the total population belongs to the poor } \\
\text { and can not live on wages; due to problems with employment } \\
\text { suffers most of the inhabitants of the city; businesses are } \\
\text { faced with the inability to compete with Chinese manufactur- } \\
\text { ers }\end{array}$ \\
\hline 2 place & Astrakhan & 0,68 & $\begin{array}{l}\text { more than } 15 \% \text { of citizens do not have enough money to buy } \\
\text { products; the most severely affected transport and utilities }\end{array}$ \\
\hline 3 place & Penza & 0,60 & Low salaries; many have to look for a part-time job \\
\hline 4 place & Volgograd & 0,59 & $\begin{array}{l}40 \% \text { of young people have problems with employment or work } \\
\text { in low-paid jobs; more than } 3 \% \text { of the population remain be- } \\
\text { low the poverty line }\end{array}$ \\
\hline 5 place & Saratov & 0,55 & $\begin{array}{l}60 \% \text { of Saratov considered poor, and } 25 \% \text { of citizens are } \\
\text { poor; low wages; problems with health care, environment and } \\
\text { food quality; high mortality }\end{array}$ \\
\hline 6 place & Rostov-on-Don & 0,53 & $\begin{array}{l}\text { more than half of the population belongs to the poor; un- } \\
\text { employment; low level of social security of pensioners and } \\
\text { people of pre-retirement age }\end{array}$ \\
\hline 7 place & Lipetsk & 0,52 & $\begin{array}{l}20 \% \text { of residents are below the poverty line; the least devel- } \\
\text { oped areas in the city are considered to be medicine, utilities } \\
\text { and social services }\end{array}$ \\
\hline
\end{tabular}

Center-Periphery migration, accumulation of population in the centers of attraction (mainly regional centers) is not a new phenomenon for Russia. The entire long history of urbanization can be partly included in this category of population mobility.

The most significant share of the employed population leaving for work outside its subject is in Leningrad region (20.9\%), Moscow region (19.3\%), Republic of Adygea (16.5\%), Chuvash Republic $(12.5 \%)$, Republic of Kalmykia (11.8\%), Jewish Autonomous region (10.1\%), Tula region $(9.5 \%)$, Vladimir region $(9.5 \%)$.

The main subjects of the Russian Federation, employing citizens from other regions, were Moscow (1.5 million people, or $20.9 \%$ of the employed population of the region), Tyumen region (with Autonomous districts) (353 thousand people, or 18.9\%), Moscow region (204 thousand people, or $5.1 \%$ ), St. Petersburg (253 thousand people, or $8.4 \%$ ), Krasnodar region (63 thousand people, or $2.4 \%$ ). Above the average Russian level (3.9\%) the share of labor migrants was observed in the Republic of Sakha (Yakutia) $(6.1 \%)$, the Republic of Komi (4.1\%), Kamchatka $(7.1 \%)$, Magadan region (6.5\%).

According to the microeconomic model of individual choice (M. Todaro, L. Maruzhko), individual rational individuals decide to migrate on the basis of an analysis of the costs and profits associated with the move. A key component is the assessment of the expected benefits of the earnings gap. It is worth noting that the level of wages should be sufficient to cover the costs of movement (table 2) $[14]$.

1 The poverty index is calculated using three main indicators: life expectancy, level of education of the population, level of real incomes of the population. 
Average monthly nominal accrued wages of employees in the full range of organizations in the economy in the subjects of the Russian Federation for 2015-2017

\begin{tabular}{|l|c|c|c|}
\hline \multicolumn{1}{|c|}{ Subjects of the Russian Federation } & $\mathbf{2 0 1 5}$ & $\mathbf{2 0 1 6}$ & $\mathbf{2 0 1 7}$ \\
\hline Russian Federation & 34030 & 36709 & 39167 \\
\hline Central Federal district & 41961 & 45943 & 48593 \\
\hline Moscow region & 40643 & 42656 & 46836 \\
\hline Moscow & 64310 & 71379 & 73812 \\
\hline The North-Western Federal district & 37931 & 41076 & 44450 \\
\hline St. Petersburg & 44187 & 48703 & 53740 \\
\hline Southern Federal district & 25471 & 26964 & 28712 \\
\hline North Caucasus Federal district & 21720 & 22963 & 24400 \\
\hline Volga Federal district & 25632 & 27265 & 29189 \\
\hline Ural Federal district & 39083 & 41464 & 43977 \\
\hline Tyumen region & 56616 & 60090 & 63789 \\
\hline Siberian Federal district & 29616 & 31569 & 33718 \\
\hline Far Eastern Federal district & 43164 & 45786 & 48952 \\
\hline
\end{tabular}

\section{Results}

To date, among the regions of the country can be more clearly identified regions, receiving and giving the population. The host regions are located compactly and correspond to densely populated areas, where $80 \%$ of the population (120 million people) is concentrated. This zone is located from Kaliningrad to Novosibirsk region (South of Western Siberia) and from Karelia (excluding the rest of the European North) to Krasnodar region. The regions giving away the population are located in a non-compact way.

In General, $17 \%$ of the population (26 million people) lives in this territory. These include the Northern part of the Urals, Eastern Siberia, the Far East, Dagestan, Chechnya, Ingushetia. Almost all the host regions of Russia are more or less affected by the crisis, which prevents the successful resettlement and social adaptation of internally displaced persons. Describing the socio-economic processes taking place in the host areas, it can be noted that they generally coincide with the allRussian: there is a drop in the level of production; industries with previously successful dynamics of indicators in the last 3-4 years began to experience some difficulties.

Migration significantly changes the age and sex structure of the population of both the giving and receiving territories. Settlements, which directed the flow of migration, are called settlements-recipients, of whom directed the flow of migration - settlements-donors. Population migration has a strong impact on population distribution, population size and composition (table 3) [14].

According to the labor force survey, the number of employees working outside the constituent entity of the Russian Federation in which they live, including those working in the territory of another state [9], averaged 2.9 million in 2017, and 2.7 million in 2016 (fig. 1).

The vast majority of voluntary migrants are young people (usually under 35 years of age). Young people are the most dynamic social group that is committed to improving their lives. The period of youth is associated with the search for identity (E. Erickson), intensive socialization (I.S. Kohn), professional development and search for a life partner. These age characteristics allow us to highlight some of the characteristics of young migrants. First, commitment, the desire in a short time to get the maximum satisfaction of needs (in the broad sense of the word). Leaving the parental home, young people are forced to provide for themselves, and often also to support their family, so they take up any work that can bring them income. Second, the willingness to limitations and hardships in achieving their goals. Young migrants are able to 
Interregional labor migration of the employed population aged 15 years and older in the subjects of the Russian Federation in 2017

\begin{tabular}{|l|c|c|c|c|}
\hline \multirow{2}{*}{ Region } & \multicolumn{2}{|c|}{$\begin{array}{c}\text { Number of employed popula- } \\
\text { tion, thousand people }\end{array}$} & \multicolumn{2}{c|}{$\begin{array}{c}\text { As a percentage of the employed } \\
\text { population of the region }\end{array}$} \\
\cline { 2 - 5 } & $\begin{array}{c}\text { entering the } \\
\text { work in the } \\
\text { subject }\end{array}$ & $\begin{array}{c}\text { leaving for } \\
\text { work in other } \\
\text { subjects }\end{array}$ & $\begin{array}{c}\text { entering the } \\
\text { work in the } \\
\text { subject }\end{array}$ & $\begin{array}{c}\text { leaving for } \\
\text { work in other } \\
\text { subjects }\end{array}$ \\
\hline Russian Federation & $\mathbf{2 8 3 6 , 0}$ & $\mathbf{2 8 3 6 , 0}$ & $\mathbf{3 , 9}$ & $\mathbf{3 , 9}$ \\
\hline Central Federal district & $\mathbf{1 7 5 0 , 5}$ & $\mathbf{1 3 3 8 , 0}$ & $\mathbf{8 , 5}$ & $\mathbf{6 , 5}$ \\
\hline $\begin{array}{l}\text { among them: } \\
\text { Moscow region }\end{array}$ & 204,0 & 766,1 & 5,1 & 19,3 \\
\hline Moscow & 1486,1 & 18,7 & 20,9 & 0,3 \\
\hline $\begin{array}{l}\text { The North-Western Federal } \\
\text { district }\end{array}$ & $\mathbf{3 1 6 , 4}$ & $\mathbf{2 5 9 , 1}$ & $\mathbf{4 , 4}$ & $\mathbf{3 , 6}$ \\
\hline $\begin{array}{l}\text { among them: } \\
\text { Leningrad region }\end{array}$ & 20,1 & 197,0 & 2,1 & 20,9 \\
\hline St. Petersburg & 253,0 & 6,2 & 8,4 & 0,2 \\
\hline Southern Federal district & $\mathbf{9 7 , 6}$ & $\mathbf{1 9 6 , 5}$ & $\mathbf{1 , 3}$ & $\mathbf{2 , 6}$ \\
\hline North Caucasus Federal district & $\mathbf{2 0 , 4}$ & $\mathbf{1 0 4 , 3}$ & $\mathbf{0 , 5}$ & $\mathbf{2 , 6}$ \\
\hline $\begin{array}{l}\text { among them: } \\
\text { Stavropol territory }\end{array}$ & 8,6 & 23,3 & 0,7 & 1,8 \\
\hline Volga Federal district & $\mathbf{9 4 , 0}$ & $\mathbf{6 3 4 , 9}$ & $\mathbf{0 , 6}$ & $\mathbf{4 , 4}$ \\
\hline $\begin{array}{l}\text { among them: } \\
\text { Republic of Bashkortostan }\end{array}$ & 4,6 & 155,0 & 0,2 & 8,2 \\
\hline Ural Federal district & $\mathbf{3 9 3 , 2}$ & $\mathbf{9 2 , 6}$ & $\mathbf{6 , 5}$ & $\mathbf{1 , 5}$ \\
\hline Tyumen region & 353,3 & 29,6 & 18,9 & 1,6 \\
\hline $\begin{array}{l}\text { among them: } \\
\text { Khanty-Mansiysk autonomous } \\
\text { region - Ugra }\end{array}$ & 202,5 & 1,1 & 22,8 & 0,1 \\
\hline $\begin{array}{l}\text { Yamalo-Nenets autonomous } \\
\text { region }\end{array}$ & 111,4 & 0,2 & 36,7 & 0,1 \\
\hline Siberian Federal district & $\mathbf{7 5 , 5}$ & $\mathbf{1 8 0 , 9}$ & $\mathbf{0 , 8}$ & $\mathbf{2 , 0}$ \\
\hline Far Eastern Federal district & $\mathbf{8 8 , 5}$ & $\mathbf{2 9 , 7}$ & $\mathbf{2 , 8}$ & $\mathbf{0 , 9}$ \\
\hline & & & & \\
\hline
\end{tabular}
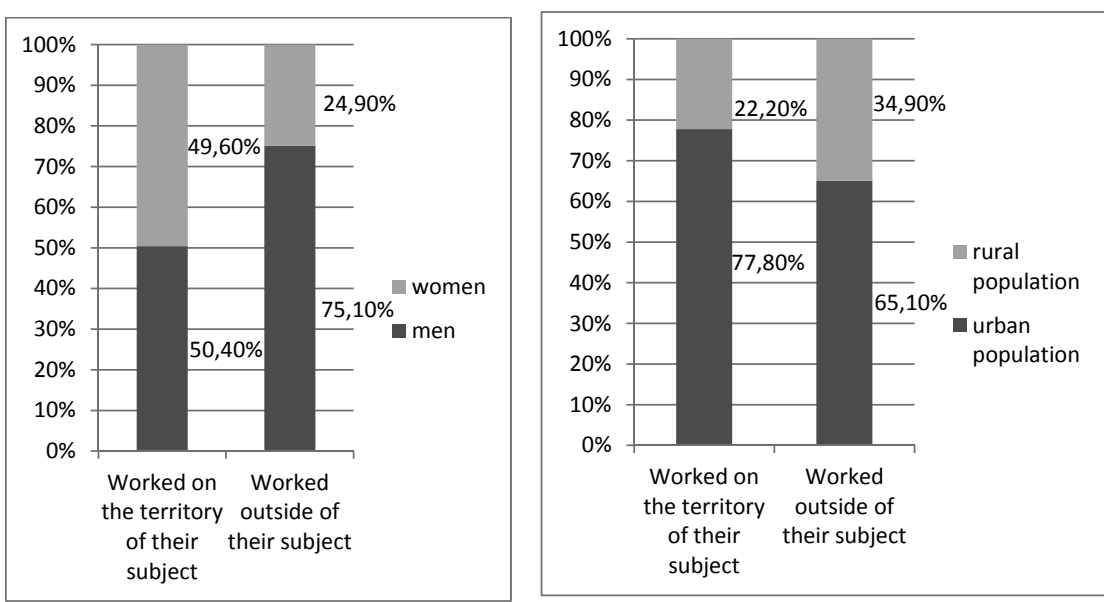

Figure 1. The structure of the employed population by sex and type of area depending on the location of work in 2017 , in \% 
live in minimal comfort, in unsuitable accommodation, limiting themselves in food, neglecting personal hygiene, etc. Third, the difficult financial situation, as the costs of young migrants are several times higher than those of their peers (housing, food, transportation, clothing, footwear, basic necessities), and the opportunities for income are approximately equal. Fourth, close emotional contacts with the new environment are of great importance for this category. Young people tend to find emotional support among new friends, easily make friends. But often these contacts have a socio-economic context associated with the desire to gain a foothold in a new place (for example, marriage with a resident of the area).

Hidden reasons may be the desire to separate from parents, to see the world and "show themselves", the hope to find a better destiny far from their homes, to arrange their lives in a way that is not possible at home, and, in the end, the reluctance to live "according to the pattern", to repeat the fate of their parents. An example is the continuous migration of young people to Moscow, "to conquer the capital". At the same time, the move is seen by young people as a springboard for a new, better life, a brilliant career, success.

Thus, the specificity of young people's migration is that the migration of young people has a high level; it is in the direction of large cities; the young people have varied requirements for the place of residence; migration of young people may take place in the absence of push factors. Age selectivity of migration was noted by E. Ravenstein, and later his ideas were developed and reinterpreted by E. lee. The term "differential mobility" was coined by Dorothy Thomas. In General, the age selectivity of migration is thoroughly studied and observed most often. In particular, Louis Castro conducted a fundamental study of age profiles of migrants on empirical data.

The Russian Federation, with its vast territorial extent and significant differentiation in living conditions in different regions, has considerable potential for internal displacement of young people. Youth migration coincides with the General direction of migration flows, but, as a rule, this direction is more pronounced. Migratory orientation of young people is aimed strictly in the direction of regions with the best conditions of life, in the direction of large cities. And the best living conditions for them, unlike older generations, are not limited to employment opportunities and earnings. The younger generation also makes cultural demands to the area where it moves. At the same time, the cultural needs of young people, depending on the level of education and General culture, vary from the availability of bars and discos to the availability of theaters and museums. Thus, where migrating representatives of older generations are satisfied with little, young people are looking for the best for themselves.

Migration to the big city is upward vertical mobility and vice versa - vertical mobility is expressed in the change of place of residence. R. Park writes that "changes in occupation, personal success or failure - in short, changes in economic and social status - are usually expressed in changes of location". P. Bourdieu writes about the existence of social struggle for spatial profits. Such a struggle can be both collective and individual. At the same time, proximity to the center is an indicator of success or defeat in this struggle, which increases the status of young people. This determines the increasing social distance between the social environment of the native and big city, and moved to the metropolis youth is at a higher level of social hierarchy than their friends from their hometown.

Young people leaving for the big city are generally a high-resource group that is able to ensure the development of the region. A large city, accepting young people, thereby accumulates advantages over small and medium-sized cities, giving their resources to another locality. Thus, the importance of youth migration for the societies of large, small and medium-sized cities is expressed in the strengthening of their polarization.

The youth labour market is a special socio-demographic segment of the Russian economy, subject to its own laws that must be taken into account in employment policy.

Young people in the modern world are characterized by unstable attitudes, lack of work experience and work experience and, as a result, a relatively low professional status. Due to the 
over-saturation of the labor market with more competitive categories of the population, young people are a fairly pronounced risk group. At the same time, unlike other socially vulnerable groups (persons with disabilities, women), youth is the most promising category of the labor force. Not yet fully formed as a subject of labor activity, it is the most susceptible to all changes, has the ability to a constant change of labor functions, great opportunities for professional growth, the longest period of future employment.

In the context of market relations, the problem of youth employment acquires new properties. On the one hand, employment issues are extremely important for young people, on the other not everyone is able to realize their needs in the professional sphere.

The situation of young people in society is determined by a number of objective and subjective factors: the level of material security, the opportunity to realize themselves in the professional sphere, to get an education, to make a career, to ensure their civil rights and social guarantees. Youth unemployment stands out when considering the problems of employment due to the particular severity of its negative consequences.

The unemployment rate among young people aged $16-26$ is high in the Russian Federation. Among the officially registered unemployed, the share of young people over the past 5 years is $35 \%$ or more. Employment is hampered by the level and quality of education and the lack of demand for graduates in the labour market. Now more than half of graduates can not find a job in the specialty, which negatively affects the professional development of a person and the definition of his life path [8].

Among the employed population working outside the region, the proportion of young people is higher and the proportion of persons over 45 years of age is lower than among the employed population working in their territory. The average age of employed persons working outside their region was 38.5 years in 2017; working in their territory - 41 years (fig. 2) [9].

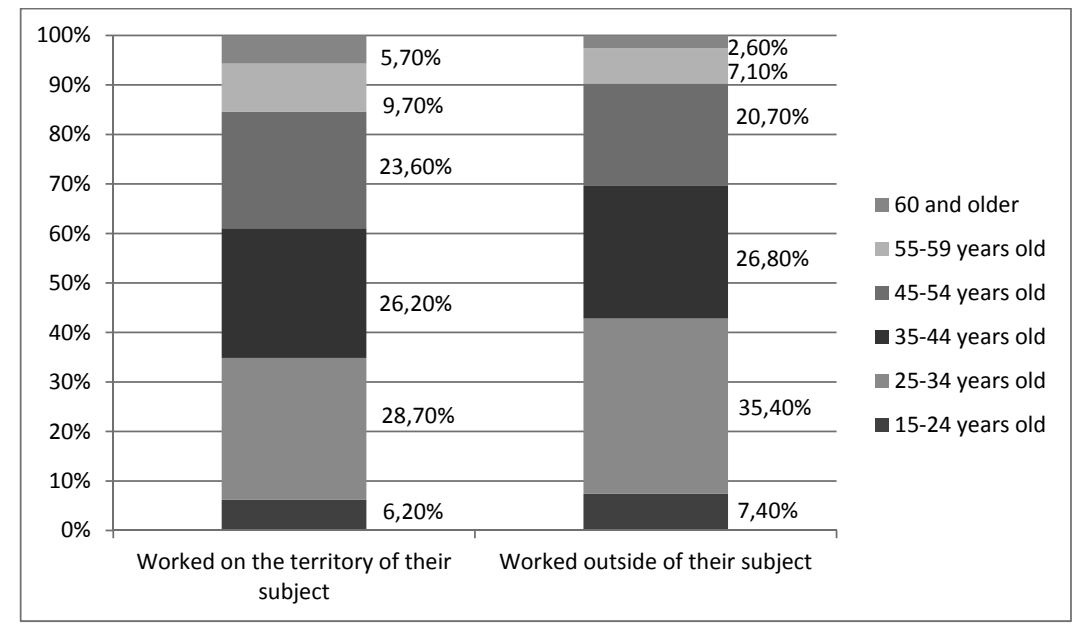

Figure 2. Structure of the employed population by age and location of work in 2017 , in $\%$

In the structure of the employed population traveling to work outside its territory, $86 \%$ were persons working in organizations (legal entities), $2 \%$ - individual entrepreneurs and individuals working on an individual basis, $12 \%$ - employees of individual entrepreneurs and individuals.

From among the domestic labor migrants 663 thousand people $(23.4 \%)$ are employed in construction, 352 thousand (by $12.4 \%$ ) in the trade, 335 thousand $(11.8 \%$ ) in the transportation and storage 251 thousand $(8.8 \%)$ in mining, 248 thousand $(8.8 \%)$ in manufacturing.

Discussion

Migration is a complex and controversial process. With a number of advantages and positive results for the development of receiving and sending countries, it also leads to negative 
consequences. The more the country's population is involved in migration processes, the more acute its consequences are.

It is known that around the powerful centers of attraction of the population formed a characteristic ring of depressed areas, the population of which flows into the city. And the larger the center and its attractive power, the larger the diameter of the ring. One can clearly see the depressive ring around Moscow with a record radius of about $500 \mathrm{~km}$. In addition, one can observe a "horseshoe" of similar nature around St. Petersburg (radius of about 200-250 km), a semicircle to the South of Barnaul (radius of 100-120 km), a ring around Yekaterinburg (radius of about $150 \mathrm{~km})$, Kazan $(80-100 \mathrm{~km})$. The more powerful the center, the larger the diameter of the ring. It is expected that the most depressed regions are formed in the area of migration attraction of several centers. For example, areas on the border of Tver and Novgorod regions. They are also influenced by Moscow and St. Petersburg in addition to their regional centers. Or the Eastern regions of Kursk and Orel regions, which fall into the sphere of migration interests of seven regional centers at once: Belgorod, Kursk, Orel, Tula, Ryazan, Lipetsk and Voronezh. North-West of the Kurgan region: Chelyabinsk, Yekaterinburg, Tyumen and strongly inferior to megacities modest mound.

Demographic consequences. According to the forecast, significant changes in the structure of the population are expected, the population of working age - the main source of formation of labor resources - will be reduced. Due to migration, the natural decline of the population is less and less compensated. In many regions of the Russian Federation, the decrease in migration population growth is taking place against the background of a significant reduction in the population as a result of increased mortality and reduced fertility. The mass departure of young people effectively deprives the population of the hinterland of a sustainable demographic future. The study of youth migration, based on the data of the last two censuses in Russia, showed that up to $70 \%$ of school graduates leave the regional periphery, there is a so-called voting feet. Since young people are mainly involved in migration, their movement to large cities (mainly regional centers) accelerates population aging and depopulation in the periphery [15]. The constant migration outflow of the population over a long period forms a very special demographic structure - "the Kingdom of elderly women" (the Russian reality of recent decades). In a difficult situation remains the older generation, which has to build their lives in very different, unusual conditions. It is noteworthy that one of the largest age groups of the population are (!) women aged 80-85.

We should also note the social and psychological consequences of migration processes: the situation of migrants is such that they feel uncomfortable both in a foreign country and on their return home. Leaving for work, they lose indefinitely connection with family, friends, native nature. They feel uncomfortable and at the new place of residence because of the uncertainty to find a suitable job. An unusual environment, sometimes even an unfamiliar language, a different mentality reinforce the oppressive state of migrants.

Although migration contributes to the well-being of families, the preservation of the family and the upbringing of children is hampered by the absence of one or both parents.

The main social problems of migrants today are: housing problems and employment problems.

The resettlement programme for refugees and internally displaced persons has not paid off. On the allocated money it was favorable to settle people in rural areas, and they went there where there was though any housing, sincerely believing that it is-the main thing and they, in the majority the city inhabitants, will be able to adapt to new conditions. Nothing like this happened: depressed areas remained depressed, and people tried to move to the city. Time, effort and resources were wasted. Depressive and deserted areas, which leaves the local population in Russia enough.

Conflicts. From the effects of population migration to the center suffer not only the regionsdonors and regions-recipients. The influx of migrants contributes to the growth of real estate 
prices, increased competition in the labor market, lower living standards, aggravation of other social problems, especially in the field of education and health, criminalization of the situation in Russia, and it has significantly increased the burden on the environment of the host country.

This is especially noticeable in Moscow, where the social stratification of the population is increasing, some areas are becoming isolated and disadvantaged. Land in the capital is very expensive, so developers are trying to get the most out of each square meter and build "human" the same type of high-rise buildings, without thinking about the infrastructure. Hence - the queue to kindergartens, the tense situation with places in schools, the lack of clinics, lack of Parking spaces. Buy these apartments visitors from the regions, poor people who managed to save up for one-room apartment in a panel house on the outskirts of Moscow, or residents of the Moscow region, who have long worked in the capital and were able to save money to "get closer" to her. And the bulk of the apartments purchased through mortgage lending, and people for 20-30 years are forced to pay loans. As for young people, almost all young people live in rented apartments, paying the bulk of their wages.

According to the specialists of "INCOM-real estate", some budget suburban Moscow locations eventually risk becoming ghetto areas, where a significant part of the population will consist of migrants. Due to the fact that tenants often change, in a deplorable state gradually come entrances and house territories. The existing infrastructure is not changing for the better-banks, beauty salons and bakeries are closing. Their place is occupied by pawn shops, liquor stores, car washes, etc. This "leisure" leads to an increase in crime: theft, attacks on residents, car theft. Living in disadvantaged areas is becoming dangerous.

Today, real national enclaves, diasporas are being formed in such marginal locations, which live by their own laws and concepts. The strengthening of nationalist and separatist sentiments has in some cases led to clashes on an inter-ethnic and inter-religious basis.

Ecology also leaves much to be desired. The load on public transport, power generation, waste processing of the growing city is significantly increased.

\section{Conclusion}

In recent years, migration does not ensure the redistribution of the population across the country in order to balance supply and demand in the labor market. The emigration of young people leads to a reduction in the labour force among the most productive age group. The revival of the national economy, the inevitable territorial and sectoral imbalances require a more active redistribution of the population and labor resources within the country, which necessitates the development of mechanisms to stimulate labor migration of citizens, including through the development of the housing market and solving social problems.

\section{References}

1. Abylkalykova S.I., Vinnik V. Economic theory of migration: labor force and the labor market // Business. Society. Authority. 2012. No. 12. P. 1-19.

2. Kashnitsky I.S. Migration of youths in Russia: impact on age structure. URL: https://www. hse.ru/pubs/share/direct/document/166661595.

3. Khudaverdyan V.Ts. Youth migration in the modern world: causes and consequences // Knowledge. Understanding. Skill. 2012. No. 2.

4. Migration // Wikipedia. URL: https://ru.wikipedia.org/wiki/.

5. Migration and its types. URL: https://ppt-online.org.

6. Molodikova I.N., Yudina T.N. Migration Strategies of Ukrainian Migrants: EU or Russia // Contemporary Problems of Social Work. Vol. 2. 2016. No. 3 (7). P. 62-71.

7. Nazarova E. Features of modern migration processes // Sociological research. 2000. No. 7. P. 106-116.

8. Nikolaeva P.P. Youth in the social space of Russia. M.: Infra-M, 2008. P. 109.

9. On interregional labour migration in 2017. URL: http://www.gks.ru/free_doc/new_site/ population/trud/migrac/mtm_2017.htm\#_ftn1. 
10. Osadchaya G.I. Migrants from the Countries of the Eurasian Economic Union (EEU) in Moscow: Social and Professional Background // Contemporary Problems of Social Work. Vol. 3. 2017. No. 3 (11). P. 113-120.

11. Poverty // Wikipedia. URL: https://ru.wikipedia.org/wiki/\%D0\%91\%D0\%B5\%D0\%B4\%D0\% BD\%D0\%BE\%D1\%81\%D1\%82\%D1\%8C\#cite_note-21.

12. Problems of population migration in Russia. URL: https://otherreferats.allbest.ru/ geography/00185332_0.html.

13. Ravenstein E.G. The Laws of Migration // Journal of the Statistical Society of London. Vol. 48. 1885. No. 2. P. $167-235$.

14. Rosstat. URL: http://www.gks.ru/wps/wcm/connect/rosstat_main/rosstat/ru/statistics/ wages/.

15. Sankova I.Yu., Shinkorenko A.V. Migration processes in the youth environment // Bulletin of the scientific society of students, postgraduates and young scientists. 2014. No. 2. P. 57-63. URL: http://www.amgpgu.ru/upload/iblock/425/sankova.

16. The phenomenon of youth migration. URL: https://refdb.ru/look/2182187-pall.html.

17. Tikhonova N.E., Gorshkova M.K. Poverty and the poor in modern Russia. M.: The Whole World, 2014. $304 \mathrm{p}$.

18. Yudina T.N. Sociology of migration: textbook for high schools. M., 2006. 272 p.

19. Yudina T.N. Labour migration into Russia: The response of state and society // Current Sociology. Vol. 53. Issue 4. 1 July 2005. P. 583-606+733-734.

20. Yudina T.N., Osadchaya G.I., Leskova I.V., Dolgorukova I.V., Kireev E.Y. The Eurasian Economic Union: Migration risks // Mediterranean Journal of Social Sciences. Vol. 6. Issue 4. 1 July 2015. P. 451-457.

\section{REFERENCE TO ARTICLE}

Kozhanova, V.P., Bagrova, N.V. \& Papkova, N.E. (2018) Social Consequences of the CenterPeriphery Migration of the Population in Russia, Contemporary Problems of Social Work. Vol. 4. No. 4 (16). P. 27-36. DOI: 10.17922/2412-5466-2018-4-4-27-36 (International bibliographic description).

\section{CONTACT INFORMATION:}

Kozhanova Victoria Petrovna

Expert of the Department of Scientific and Technical Information

Russian State Social University

Wilhelm Pieck, str. 4, build. 2

129226 Moscow, Russian Federation

E-mail: vikylasor@mail.ru

\section{Bagrova Natalia Vladislavovna}

Editor in Chief of Operative Polygraphy Sector

Center for Marketing Communication

Faculty of Communication Management

Russian State Social University

Wilhelm Pieck, str. 4, build. 2

129226 Moscow, Russian Federation

E-mail: bagrovan@bk.ru

\section{Papkova Natalia Evgenievna}

Expert of the Department of Scientific and Technical Information Russian State Social University

Wilhelm Pieck, str. 4, build. 2

129226 Moscow, Russian Federation

E-mail:marova@inbox.ru 


\section{PSYCHOLOGY}

\section{Bagrova N.V.,}

Editor in chief of Operative Polygraphy Sector of the Center for

Marketing Communication, Faculty of Communication Management,

Russian State Social University, Moscow.

E-mail: bagrovan@bk.ru

ORCID ID: orcid.org/0000-0003-4822-5084

\section{Papkova N.E.,}

Expert of the Department of Scientific and Technical Information,

Russian State Social University, Moscow.

E-mail:marova@inbox.ru

ORCID ID: orcid.org/0000-0001-7159-086X

\section{Socio-Psychological Peculiarities of Creative Activity and Creativity in Old Age and Development Program of the Capital City for Older People}

Receiving date:
19.09.2018
Preprint date:

19.11.2018
Taking to print date:

18.12.2018

Annotation: the authors consider the new socio-cultural realities of modern Russia, as well as the General features of the socio-demographic situation in order to determine the possible directions of activation of the creative potential of the third generation. Realization of creative potential allows elderly people to become active participants of modern socio-economic and socio-cultural changes, to successfully adapt to the everchanging economic, political, social and cultural situation in the country, to respond adequately to social contradictions and social risks. Currently in Russia began to appear all sorts of resource centers, clubs, studios, organizing and uniting the elderly at various events in accordance with their interests. On the example of the capital metropolis, the authors considered the features of a variety of educational programs for the older generation.

Key words: elderly people, creativity, creativity, creativity, creativity, activization of creative potential, gerontopsychology, gerontosociology, elderly people education, active lifestyle, «silver University».

JEL classification: $A 130, A 230$.

\section{Introduction}

The emerging socio-demographic situation in modern Russia actualizes the attention of researchers to the problems of older people and attracts society and the state to activate the 
experience and knowledge, intelligence and personal potential, creativity and creativity of older people to adapt them to modern society.

Agree with the opinion of Russian researchers that «older age, like every other, has its positive and negative aspects associated with losses, but has advantages, providing a person the opportunity to live this period of his life actively, realizing the interests, aptitudes in the borders that are optimal from the point of view of the opportunities and needs of the older person» $[12$, p. 13].

As L.P. Mishhiha rightly points out, «the older generation today requires a well-thought-out system of resocialization, qualified psychotherapeutic assistance, opportunities to realize their creative potential, which will ensure positive socialization of the individual in the period of late ontogenesis and improve the quality of life of the individual due to special attention to the development of his creativity» [15].

\section{Methodology}

\section{The degree of development of the problem under consideration}

Scientific directions, which are associated with the study of different aspects of aging, began to appear only in the XX century. I would like to mention among them gerontopsychology, in which explores:

$>$ the features of the psychological state and the development of the intellect, cognitive and cognitive abilities in the old age (B.G. Anan'ev, L.I. Antsyferov, I.V. Davidov, I.S. Kon, A.G. Lidere, V.V. Frolkis, E. Erikson, D.B. Bromley, N. Krause, etc.);

personal characteristics elderly (L.V. Borozdina, O.V. Krasnov, S.G. Maksimova, 0.N. Molchanova, N.S. Prjazhnikov, N.F. Shakhmatov, P. Costa, N. Haan and R. Nelson);

$>$ features of the psychological help and support (B.G. Anan'ev, R.M. Granovsky, 0.V. Krasnova, A.G. Lidere, N.F. Shahmatov, E. Erikson, D.S. Fenn, J. Franklin, A.K. Stanton, etc.). It often happens that research in the field of gerontological psychology combined with sociological research, contributing to the development of such direction as gerontosociology that explores:

$>$ features of socio-psychological adaptation and socialization of the elderly (L.I. Antsiferova, K.T. Aref'eva, L.N. Zakharova, I.S. Kon, V.A. Krasnov, V.S. Lazarev, S.V. Shilov, etc.);

$>$ educational influence people «silver age» for socialization (P. Wentzel, W. Braun, H. Reggentin, etc.);

$>$ features of the motivational and needs sphere of human life of the third age, including the issues of motivation of participation in the educational process (0.V. Agapova, N.M. Bozhko, N.B. Sekareva, G.S. Sukhobskaya, etc.);

$>$ features of successful aging (L.I. Antsyferova, N.F. Chess, E. Erikson, R.J. Havighurst, S.D. Heidrich, M.C. Stallings, and others);

$>$ the influence of education in old age on total life satisfaction (G.A. Klyucharev, S. Becker, E.A. Cook, T.T. McConatha, etc.).

\section{Discussion}

In Russian reality, the aging process takes place in the conditions of tough age opposition between young people and the «rest». The demand for young people in the industrial, economic, social, cultural and other spheres of society and actively promoted by the media over the past 20 years, the «cult of youth» has led to a clear division of Russian society into two social groupsyoung and "others». "At the same time, this does not yet lead to the "extension of youth" characteristic of Western post-industrial societies as a certain lifestyle» [8].

Both objective and subjective problems prevent the full implementation of the concept of ensuring the conditions of a prosperous life adopted at the level of the official ideology in Russia, not on the basis of the principles of «quiet survival», but on the basis of the full participation of older people in the life of society due to their capabilities and desires. Among them:

- loneliness of an elderly person «both outside and inside the family; 
- violence of strangers, relatives and family members over him;

- extremely low level of material security of life;

- "off" from social life;

- recognition of the "uselessness" of an elderly person due to the reduction of his functional and labor potential;

- prevalence of estimates of elderly people as consumers in poor society, as a constantly increasing group of people whose needs are a heavy burden on younger generations, etc.» [8].

That is why it is so necessary:

- constantly maintain interest in older people to different forms of cultural and leisure activities;

- to optimize their life activity by means of cultural and leisure activities and establishment of creative contacts between specialists of cultural institutions and elderly people;

- accelerate the socialization of older people and interaction with the younger generation;

- stimulate their intellectual and physical activity;

- to develop their creative abilities and activate the creative potential of older people in the new socio-cultural realities of the development of Russia through socio-cultural activities.

Currently, many organizations dealing with the problems of older people in Russia have realized that leisure, recreation and recreation are important factors in the life of any person, and for people who are little employed in the labor sphere (the elderly and disabled), especially. Leisure implies a kind of occupation that gives a person a sense of pleasure, high spirits and joy. People come together to share common interests with friends and family, to meet their needs, to communicate, to establish public contacts and to have the opportunity of self-expression or creative activity. In the process of leisure activities such basic functions of social and cultural activities as developing, educational, cultural, creative and recreational functions are implemented.

At any age, it is important to the development of personality, its growth, evolution. The continuation of the progressive development of personality in adulthood is facilitated by the content and creative nature of the way of life of an elderly person. Creativity has a very special place in the lives of older people. "The motivation of creative activity allows us to maintain high efficiency until old age. <...> After 70 years among prominent figures science and art rarely meets the kind or a different form of senile dementia, dementia. The desire to create is one of the leading factors in psychological and biological longevity» [17, p. 576].

In general, the question of the ability of people of «silver age» to creativity is extremely difficult. Among the different approaches to its solution there are two main ones. Proponents of one view argue that there is a specific capacity for creativity - creativity that can be highlighted and changed. Supporters of another point of view believe that the concept of «ability to create» refers to a special configuration of the basic abilities of the individual. "Immersion in one's own or someone else's creative activity contributes to the social and psychological behavior of the elderly due to the fact that it increases creativity, innovative aspirations, which are often lacking in the elderly due to their age characteristics. It is necessary for the elderly to implement their social activity, to adequately address unforeseen, indeterminate situations from which you cannot emerge on the basis of stereotypical behavior» [12, p. 173].

In fact, creativity is a characteristic of a fully functioning person, his ability to produce unique ideas, results, ways of solving problems. On the one hand, one of the main tasks of the psyche, and on the other hand, the ability of the Central nervous system to create, on the other hand, emphasizes Yu. Vagin (from the English creation - to create, create), a subjective model of the world with the help of sensory, mnestic, cognitive and affective systems in order to adapt the individual to the environment as flexibly as possible [24].

The concept of «creativity» comes from: 1) the Latin word «creation» - «creation», «creation» - and is interpreted as a level of creative talent, creativity, which is a relatively stable 
characteristic of the individual; a special kind of abilities, manifested in the success of creative activity; 2) and from the English word «creativity», meaning the creative possibilities (abilities) of a person, which can be manifested in thinking, feelings, communication, individual activities, characterize the personality as a whole and (or) its individual sides, products of activity, the process of their creation [14]. The concept of «creativity» is closely connected with creativity. In the activation of the creative potential of older people should use methods that stimulate the productivity of creative activity (according to E.P. Torrence):

$>$ to excite the interaction of intellectual, volitional and emotional functions;

$>$ provide «realistic encounter with the problem», immersion in it, emotional involvement;

$>$ clash of opposite concepts, images, ideas.

of course, it is important to consider the endowments of the older person as a system that develops throughout life, the quality of the psyche, which determines the possibility of reaching the higher (unusual, extraordinary) results in one or several activities in comparison with other people as a quality peculiar combination of abilities, ensuring the successful implementation of activities, which motivated older people. The researchers note that «the personality of a creative person is tolerant of aging. The diversity and Versatility of interests - one of the most striking features of a creative person. The interests of the creative person are characterized by the fact that at any age her professional interests prevail over others (family, sports, etc.), and in the sphere of non-professional interests are dominated by those aiming at the interaction with the macro-environment (politics, social activity)» [12, p. 62], and «independent work regardless of their level in the same way as any other hobby (hobby), becomes the same sense-motive, which, as head of the hierarchy of motives of the individual, helps to make sense of others aspirations and needs of the older person» $[12$, p. 173].

There is a process when an elderly person begins to build his own life in accordance with his inner logic. V. Frankl wrote: «The Person leading a productive life, becomes a decrepit old man, on the contrary, mental and emotional qualities developed in the course of life saved, although physical strength is weakening» $[11$, p. 24].

Creative potential (lat. potential - «opportunity», «power», sources, means, reserves that can be used to solve problems, achieve a certain goal; the activity side of human existence, its resource of possible actions) of a person is the basis for creativity. The majority of researchers define creativity as «the system as the intellectual and physical powers of man, oriented to creation of new, positive social values» [20, p. 441].

The problems of creativity and creative productivity in later periods of human life, activation and use of creative potential are widely covered in the scientific literature, but they are rarely considered in terms of activation of the creative potential of older people. At the same time, knowledge of the initial stages of activation of the creative potential of older people makes it possible to properly organize the interaction of this category of population and employees of social and cultural institutions, which should take into account the motives of a person that inhibit or stimulate the emergence and manifestation of creativity. «This is a very complex and difficult problem - the problem of human creativity and his personal qualities» [1, p. 257].

While activating the creative potential of older people, it is necessary to take into account its content, which includes a set of different abilities and potentials: transformative-subject (skills, abilities), cognitive (intellectual abilities), axiological (value orientations), communicative (moral and psychological qualities), artistic (aesthetic abilities). For older people, whose creativity encourages motivation to be active, often the act itself, the process of creation, not the result, is important. A very important point in the work of older people is the recognition of the products of their creativity by close people. At this age, it is so necessary to be necessary for them. Under these conditions, there is a sense of security and confidence of the older generation in the future. Studies conducted in gerontological centers, as well as in social welfare centers, have shown that psychological comfort is a necessary condition for a favorable old age [3]. 
And, generally speaking, do not think that after 60 years old age begins - creativity can be a great incentive for a new interesting and rich stage of life. One of the interesting phenomena of old age is unexpected outbursts of creativity. By the way, for someone who is engaged in a favorite thing, there is no age. Doing interesting things helps the elderly to spend time usefully, not to think about the bad and to maintain a decent level of intellectual and physical shape. This is facilitated not only by social assistance services for the elderly, but also by specially created social institutions for adult education, new forms of leisure and a new culture of family relations, the system of organizing free time for people of the third age (travel, clubs, courses, classes, etc.) [3].

I must say that in the study of the features of the development of the elderly in Russia at the end of the twentieth century, an important place began to occupy the theory of Russian psychologists, which marked the emergence of new scientific ideas about the possibilities of development in the late period of life, particularly emphasized the ability to develop the personality of an older person, allowed to develop the concept of personal self-determination of an elderly person. Some researchers consider the period of late adulthood as the «age of development». So, L.P. Mischikha, dealing with the problem of anti-aging, believes that «the well-being of an elderly person is determined by a number of factors determined by his physiological state of being (physical ability to "be"), mental (adequate perception of the world, the activity of cognitive and emotional processes), social (social demand, communication), personal maturity (willingness to develop), way of life, mental model of old age, active creative activity, assimilating all the existential States in the dimension of life "I am" and "I want to be"» [17].

While discussing and analyzing the subject under consideration, it is certainly necessary to speak about the fundamental legislative acts adopted in our country. Federal law No. 273-FZ of 29 December 2012 «On education in the Russian Federation» (amended, 2018) and the National doctrine of education in the Russian Federation proclaimed the idea of lifelong learning. The Constitution of the Russian Federation guarantees the human right to education throughout life. At the moment, the system of gerontological education (education of elderly people) is actively developing in Russia.

Not all, however, this direction changes so successfully and happy. The changes that have occurred in Russia over the past decade, indicate the lack of necessary conditions for a comfortable existence of older people in society. In 2014, President of the Russian Federation Vladimir Putin held a meeting of the Presidium of the State Council on the development of the social protection system for elderly citizens, one of the topics of which was the organization of leisure activities for the older generation. According to the President: «...many pensioners have the opportunity to work in their free time, but you need to use what is left except work. This includes creative hobbies, communication, sports. In a number of large cities, the necessary infrastructure is already being created, not only in the system of social services, but also in the spheres of culture, education, sports and tourism. Civil society structures and regional branches of leading political parties are involved in this work. This experience should certainly be used in the preparation of the Strategy» [9].

A characteristic feature of the present time is that a significant part of the elderly tends to an active lifestyle, getting positive emotions and getting rid of boredom and loneliness. In addition, the majority of pensioners are committed to self-development and self-realization [9]. In this regard, the problem of leisure activities of the third age is particularly relevant, because the rich and varied leisure significantly improves the health of the elderly, forms an active life position, helps to overcome difficulties and fears.

An elderly person should feel like a full member of society, have the right to rest, initiative and creativity in the field of leisure, i.e. to live a full life that meets modern ideas. So, L.S. Sukhova rightly notes that full life of many older people is impossible without granting them various types of assistance and services relevant to their social needs [22, p. 108]. 
At present, various resource centers, clubs and studios began to appear in Russia, organizing and uniting elderly people at various events in accordance with their interests.

Let us consider the example of the capital city activities of such organizations and their proposed development programs. In Moscow, there are about 3 million pensioners, whom the city helps through the implementation of various benefits and payments. They have the right to free travel in public transport and inspection of their cars, go to health resorts and visit personal doctors, go to classes in clubs and clubs, etc. For the Government of Moscow, caring for the older generation is a priority in social policy. For this purpose, the city budget allocates almost 170 billion rubles annually.

Currently, there are 1,427 different clubs in Moscow social service centers, in particular, for the study of foreign languages, computer literacy, etc. All these clubs are visited by about 70 thousand people a year. City parks satisfied for pensioners dancing and Nordic walking. The capital's pensioners can learn foreign languages for free, master a computer or, if desired, get a working specialty.

The participants of the new educational project for the elderly called «Silver University», which starts in Moscow on November 1, will be Muscovites of retirement age: men over 60 years and women over 55 years. In the «Silver University» they will be able not only to have fun, but also to acquire knowledge and skills that improve the quality of their lives. For example, they will be able to master the computer and mobile applications, learn foreign languages, learn the basics of financial and legal literacy. In the «Silver University» it will be possible to get, for example, the profession of a nanny, a manufacturer of dolls or a landscaper of urban areas. «More than two and a half million elderly people live in Moscow, which is about a quarter of the city's adult population. Our goal is to extend their creative and professional longevity by organizing cultural and educational leisure», - said Vladimir Petrosyan, Minister of the Government of Moscow, head of the Department of labor and social protection of the city. "Silver University" will enable seniors to learn what could not learn before because of lack of time. After all, in young and Mature years, they are mainly devoted to work and care for the family». According to Vladimir Petrosyan, the training program was developed in cooperation with the Moscow city pedagogical university. At its creation, experts were based on surveys conducted in the Territorial centers of social services among the elderly. Such monitoring helped to determine the sphere of interests of the capital's pensioners [23]. Classes will be held both directly in the social service centers at the place of residence, and at the sites of the Moscow city pedagogical university, located in eight Metropolitan districts - Western, SouthWestern, Central, Eastern, North-Eastern, Northern, North-Western and Zelenograd. Each group will have 15-20 people. It is expected that by the end of the year 2600 pensioners will study at the University.

Elderly students will be able to enter one of the five faculties: Humanities, Mass communications and Informatics, Culture and Creativity, Health and Safety or psychological support of the individual. At the faculty of Humanities, elderly people will learn the basics of spoken English and German, History and culture of Moscow, as well as get acquainted with the peculiarities of volunteer work. At the same faculty will be trained such a profession as a worker of green economy. During classes at the faculty of Mass communications and Informatics pensioners will be explained how the modern information space, teach them to use modern gadgets and talk about the basics of journalism. At the faculty of Culture and Creativity will be held practical classes in dance and needlework. Here you can also learn the profession of a doll manufacturer. Students of the faculty of Health and Safety will take courses «Fundamentals of financial and legal literacy», «Health swimming» and «Food instead of drugs». And at the psychological faculty, older people will learn how to prevent and resolve conflicts, as well as to overcome psychological barriers in communication. Here pensioners will be able to get the Babysitting profession. 
The duration of General education programs will be from 24 to 36 hours. Up to 160 hours are allocated for training of working specialties. Lessons will be held at least twice a week for two academic hours. In addition to theoretical and practical classes, students will be able to attend trainings and master classes of specialists in specific areas. In addition, the University will hold festivals, recitals and evenings. At the end of training graduates will be given certificates of completion of the educational course. These will not be standard state diplomas, but documents confirming the acquired knowledge and skills.

«Silver University» is a part of the city project «Active longevity», the main objectives of which are to create conditions for the creative and professional development of older people, to improve their quality of life.

0ctober 1, Moscow celebrates the day of the older generation. More than 1350 festive events are planned at different venues of the city - from tea parties and round tables to concerts and the festival «Songs of the past», and in social service centers and boarding houses for war and labor veterans will be open days, where pensioners will be told about the opportunities for recreation, training and communication, which are in the capital.

For the elderly, the city hosts many festivals and competitions, for example: «Age.no», «Songs of the past», «Super Grandpa», and «Super Granny». Over the years, more than 6,000 Muscovites have fought for the right to reach the final of the latter. In 2017, representatives of 11 districts entered the final stage. They performed with creative numbers, which demonstrated their talents, commitment and self-confidence. Russian pop stars, theater and cinema helped to prepare for the super-grandmother competition.

Over the past seven years, average life expectancy in Moscow has increased by three years to over 77 years. Increasing life expectancy, improving the quality of medical services, improving the health of older people are gradually forming a new attitude to older age as a «better half of life». Older people tend to get more opportunities for an active rich life, to maintain good health and vigor for the longest time. Responding to these requests, the Moscow Government decided to conduct a large-scale pilot project «Moscow longevity». «Moscow longevity» is a city program for those residents of Moscow who want to lead an active lifestyle and use all the opportunities of the city for self-realization free of charge. The project will help older Muscovites to improve their health, gain new knowledge and skills. Sports sections, language classes and computer courses in each district of the city - the program includes the most popular areas. And the main feature of the program - for pensioners all sports, leisure and educational activities are organized free of charge! The organizers and customers of the classes are territorial centers of social services. To participate in the project, educational centers, cultural institutions, sports, parks and other capital organizations responded.

Recently, the project «Active citizen» has been launched, in which everyone can take part. People, including the elderly, are involved in public life, which makes them less indifferent, allows them to Express their opinion and be active.

Modern pensioners can today not only sign up for a doctor via the Internet or use the electronic registry, but also to lead an active lifestyle, visiting hobby groups, finding likeminded people and new friends.

\section{Summary}

In the new Russia, elderly people are in a particularly difficult situation, because they not only experience the loss of their internal values and life orientations, but also have to accept the values of the new era of market relations, which are reflected, among other things, in culture. In the post-Soviet period, the decline in the personal status of the majority of the elderly population due to the universality and radical changes in all spheres of society and the individual has led to the fact that «subculture becomes a way of positive re-socialization for the older generation. Older people act as a kind of unity, which has its own subculture, which is part of the General culture», - said M.S. Azarina [4]. 
In conclusion, it is necessary to identify several important provisions that are the quintessence of this study.

1. The problem of elderly people in modern Russian society is state and socially significant. Their vast life experience and high spiritual potential should be supported by all state and public structures, and should find their implementation in the social construction of Russian society.

2. The education system as the most important institution of human socialization can contribute to the decision to support older people in their new personal and professional development trajectory, focus on the development of new educational programs, the ability to realize themselves as a socially significant person, the desire to help others, to benefit people.

3. In the new educational programs for the elderly, comprehensively developing education should occupy a priority direction, due to the psychological characteristics of this age.

As reported by many media publications, has been launched in Moscow, finally, the new pilot project «Active aging». It began its work on March 1, 2018. It is from this day officially pensioners can come to the social service centers and enroll in any circle of interest, and in fact before recording in circles and sections was possible only for students. Only in the first days of March this year, for example, about 30 thousand elderly citizens of the capital enrolled in such circles.

Thus, «old age» as a social category can move from the category of problematic for the state and society to the situation of its positive solution [21]. It is so necessary for our society today.

\section{References}

1. Abramova G.S. Age Psychology: Studies: Textbook for students of higher educational. 4 edition. M.: Academy, 1999.

2. Alferova I.A. Peculiarities of Psychological Problems of Elderly People // Contemporary Problems of Social Work. Vol. 3. 2017. No. 3 (11). P. 147-153.

3. Asanova Z.S., Umarkaeva S.Sh. The Organization of Leisure of Elderly People by Means of Amateur Creativity Are Considered // Concept. 2015. Vol. 13. P. 1676-1680. URL: http://ekoncept.ru/2015/85336.htm.

4. Azarina M.S. Interaction of the Subculture of Elderly People and the Culture of Society in the Process of Their Re-socialization in the Post-Soviet Modernization. URL: http://www. gramota.net/materials/3/2012/10-1/3.html.

5. Bagrova N.V. Actual Problems of Russian Education: Ways of Their Solution and Modernization of Education // Contemporary Problems of Social Work. Vol. 3. 2017. No. 4 (12). P. 84-89.

6. Bagrova N.V., Papkova N.E. Problems of Social-Psychological Adaptation of Elderly People and Methods of Their Overcoming // Contemporary Problems of Social Work. Vol. 4. 2018. No. 3 (15). P. 65-73.

7. Bazhenova M.R., Sorikhina V.P. Flash Mob in the Development of Creative Abilities of Young People // Scientific Notes of Russian State Social University. Vol. 17. 2018. No. 2 (147). P. 112-119.

8. Does the Internet Talk About the Problems of Older People? URL: http://www.raso.ru/ articles/article27900.html.

9. Fedoseyeva I.A., Veselova Yu.V. The Development of the Aesthetic Attitude to Reality in the Elderly People in the Process of Visual Arts // Scientific Notes of the Russian State Social University. Vol. 14. 2015. No. 4 (131). P. 177-185.

10. Firsova N.G. Leisure As One of the Forms of Self-esteem of the Elderly After Retirement Is Considered // Concept. 2013. Modern scientific research. Vol. 1. URL: http://e-koncept. ru/2013/53655.htm.

11. Frankl V. Man in Search of Meaning / translation from English, German. M.: Progress, 1990.

12. Kornilova M.V. Social Services As a Way to Protect Elderly Muscovites from Social Risks // Social Policy and Sociology. Vol. 16. 2017. No. 3 (122). P. 112-119.

13. Koroleva V.A. Socio-Psychological Features of the Innovation Process in the Social Sphere // Contemporary Problems of Social Work. Vol. 3. 2017. No. 2 (10). P. 146-152.

14. Krasnova 0.V., Leader A.G. Social Psychology of Aging: Textbook. M.: Academy, 2002. 288 p. 
15. Kudrina E.L. Universities of Culture and Arts in the Preparation of a Creative Specialist for the Creative Industries. URL: http://www.gpntb.ru>win/inter-events/crimea2011/drive/127. pdf.

16. Meeting of the Presidium of the State Council on the Development of Social Protection of Older Persons // Portal «President of Russia». URL: http://www.kremlin.ru/ news/46397\#sel=22:63,22:63.

17. Mischikha L.P. Psychological Anti-aging: From Homeostasis to Passionarity // Journal of Scientific Publications of Postgraduates and Doctoral Students. 2014. P. 190-192.

18. Papkova N.E., Bagrova N.V. Social and Pedagogical Aspects of the Problems of People of «Third Age» at the Present Stage // Contemporary Problems of Social Work. Vol. 4. 2018. No. 2 (14). P. 41-48.

19. Sorikhina V.P., Fomina S.N. Realization of the Business Game «Scientific Society of Students» // Scientific Notes of Russian State Social University. Vol. 17. 2018. No. 2 (147). P. 94-102.

20. Sukhova L.S. Organization of Leisure and Free Time for the Elderly // Problems of Old Age: Spiritual, Medical and Social Aspects: Work of the Elderly / ed. A.V. Flint. M.: St. Demetrius school of sisters of mercy, 2003. P. 107-121.

21. Technology of Social Work: Textbook / ed. E.I. Kholostova, L.I. Kononova. M.: Yurayt, 2011. $503 \mathrm{p}$.

22. The Psychology of Man from Birth to Death / ed. by A.A. Reina. SPb.: Prime EURO SIGN, 2002. $656 \mathrm{p}$.

23. URL: https://www.mos.ru/news/item/30515073/.

24. Vagin Yu. Creative and Primitive: The Basics of Ontogenetic Personology and Psychopathology. Perm, 2002. $341 \mathrm{p}$.

\section{REFERENCE TO ARTICLE}

Bagrova, N.V. \& Papkova, N.E. (2018) Socio-Psychological Peculiarities of Creative Activity and Creativity in Old Age and Development Program of the Capital City for Older People, Contemporary Problems of Social Work. Vol. 4. No. 4 (16). P. 37-45. DOI: 10.17922/24125466-2018-4-4-37-45 (International bibliographic description).

\section{CONTACT INFORMATION:}

Bagrova Natalia Vladislavovna

Editor in Chief of Operative Polygraphy Sector

Center for Marketing Communication

Faculty of Communication Management

Russian State Social University

Wilhelm Pieck, str. 4, build. 2

129226 Moscow, Russian Federation

E-mail: bagrovan@bk.ru

\section{Papkova Natalia Evgenievna}

Expert of the Department of Scientific and Technical Information

Russian State Social University

Wilhelm Pieck, str. 4, build. 2

129226 Moscow, Russian Federation

E-mail: marova@inbox.ru 


\section{Papkova N.E.,}

Expert of the Department of Scientific and Technical Information,

Russian State Social University, Moscow.

E-mail:marova@inbox.ru

ORCID ID: orcid.org/0000-0001-7159-086X

\section{Problems of «Sandwich» Generation: Psychological and Gender Aspects}

Receiving date:
07.09.2018
Preprint date:

19.11.2018
Taking to print date:

18.12.2018

Annotation: against the background of global demographic changes is the rapid aging of the population. Care for elderly relatives falls on the shoulders of people of the "sandwich generation". These are men and women aged 45-65 who, like a sandwich, are caught between caring for children (often grandchildren), their spouses and their elderly parents. They experience tremendous psychological pressure and guilt, endure heavy physical exertion, sacrifice their career, do not have the opportunity to realize themselves professionally. As a rule, this practice of care has to be taken on by women.

Key words: sandwich generation, emotional burnout, guilt feelings, feminization of care practices, modernization of care for the elderly.

JEL classification: $A 130$, A230.

\section{Introduction}

We come into this world completely helpless, and parents take care of us, spending sleepless nights at the crib. Over the years, the roles change, and comes our turn "for a glass of water".

A huge number of people in the world belong to the so-called "sandwich" generation: like a filling in a sandwich, they are sandwiched between debt and another debt. The first is to raise and raise children (and even grandchildren); the second is to take care of elderly parents [15].

\section{Methodology}

One of the first terms "sandwich generation" was used by social worker Dorothy Miller in the scientific article «"Sandwich" Generation: adult children of aging people» [9]. She referred to this group of men and women aged 45-65 years, who are faced with great stress: in the family they care more about others than receive care. They are like a kind of buffer between generations, softening the blow, bear the main burden of responsibility, resolve difficult situations. Contrary to all hopes that children have matured and soon there will be a lot of free time for themselves, things are becoming more and more. Grown-up children are not as independent as we would like, the younger generation is not so hard on his feet, and the elderly - is already beginning to need support and assistance.

The cause of this syndrome lies in global demographic changes. First, the population is rapidly ageing. Today, life expectancy has crossed the 70-year mark. Secondly, there has been a shift in childbearing. Young people do not have children in 20-25 years, they postpone the birth of children up to 30 years and later. For example, if the first child was 28 years, the second may appear in 38 years or 42 years. While today's youth is much slower and is included in independent 
living than previous generations. Children leave their parents quite late: economically, psychologically, and socially inextricably linked with them. The family can have two or even three children who are just finishing school. Meanwhile, grandparents are already beginning to need special care. As a result, the middle (core) generation is literally torn between all of them. Usually the sandwich syndrome people experience at the age of 45-65 years.

The reasons for the difficulties of the «sandwich» generation are diverse and are primarily due to economic and social reasons, such as the high cost of University education, which allows graduates to stay with large loans and have to live with their parents until they can afford separate housing. Thus, according to The national research University Higher school of Economics (HSE), the age of separation from the parent family has shifted from 18-20 years to 23-25 years: young people spend much more time studying, choosing a partner and searching for themselves than their parents. According to the Fund "Public Opinion", about $80 \%$ of children 18-20 years old live with their parents; at the age of 21-23 years, this figure is reduced, but, nevertheless, remains high $-62 \%$ [16].

There is also a situation where parents help grown children to take care of their grandchildren, because they can not afford to hire a nanny or send a child to kindergarten. Recently, they say that in addition to the generation of "sandwich" there is also a generation of "club sandwich". There are more "ingredients" in it: men and women not only help their parents and grown children, but also take care of their grandchildren, that is, simultaneously engaged in three generations (or four at once, if, for example, help is needed and their own partner). They are "sandwiched" between aging parents, adult children and young grandchildren. Many of them are ill spouses or have brothers and sisters who are in serious condition, who also need care. They are often the only family members who have the time and resources to deal with surprises and crises. According to authoritative opinion polls, an increasing number of grandparents reduce their working hours, temporarily leave their positions or quit working in principle to care for their grandchildren, while still helping their children financially. It is obvious that every year the percentage of such people will grow [5].

\section{Discussion}

\section{Psychological aspect of the problem}

What is the practice of caring for elderly relatives and how to cope with the obsessive sense of guilt?

In Russia, different generations of the same family still often live together-and therefore, among them there is a generation of "sandwich". The traditional Russian way of life presupposes multi-generality and the indispensable care of family members for each other. Russians value the traditional family; the family is a more important institution for them than for residents of many other European countries [16].

At present, our society is facing a new challenge. Previously, many people died in 50-60 years, they did not have the diseases that are present in the older generations. Today, not only has the number of older people increased many times, but also the structure of diseases is changing. An increasing number of older people suffer from dementia in particular, which requires constant care and support. In fact, it is necessary to look after the parent from morning to evening. How do you do that if you're still working? Constantly asking for leave? How to cope with the balance of employment and care? It goes without saying that with the increase in the retirement age in our country, this situation will only worsen.

A person who finds himself in the position of a "sandwich" faces a variety of difficulties from a change of lifestyle (for example, if he is forced to temporarily leave work or move to live with relatives) and changes in financial condition to burnout and conflicts due to the changing dynamics of family relations.

Moreover, care may be required for several parents. There are situations when you have to travel to different parts of the city, spending half a day with one grandmother, and then half 
a day - with another. In fact, it is unpaid work without career growth, weekends and holidays. Emotionally it is extremely difficult to withstand. Taking care of children, people understand that they invest their efforts in the future: children will grow up, become independent. And here you can only maintain a certain standard of living of older relatives, contribute to their longevity, but it is obvious that close people are approaching their last line.

Of course, "sandwich syndrome" affects the physical and emotional state of people involved in care. "Firstly, these people are in a state of constant emotional deprivation, because they are accompanied by disease, aging. Secondly, increases physical activity: they have no free time, they do not belong to themselves. In this situation, there are conflicts in families - because the distribution of attention changes when there is a new object of intensive care. Even the health of people who have been in the grip of multiple care for a long time is deteriorating. In fact, this is a difficult life situation" [17].

Such an experience leads to emotional burnout, exhaustion, a sense of hopelessness and senselessness of effort, the thought of death. There are many ethical issues, a growing sense of guilt associated with the complexity of solving problems in this life situation.

Absolutely all adult children feel guilty when faced with a situation where older parents lose their independence, and in the worst case - and the connection with this world, pose a threat to themselves and loved ones. They forget to turn off the gas, leave, and then can not remember where they live. In this case, even around the clock experienced nurses can not always change the situation for the better.

The family, of course, must make some decision-to hire an assistant (if there is money for it) or someone from the family must give up their work. However, even when a nurse appears, the children feel guilty, worried that she will be poorly monitored and treated with a sick parent. And the older generation feels uncomfortable in the new conditions. Previously, they were independent, masters in their home space, and now their status has changed. The elderly themselves are wary of strangers crossing the border of their home space.

of course, it is necessary to understand that guilt in a situation where parents are becoming less and less independent, is inevitable. "If a person, trying to help another, does it to the detriment of his life, the psyche works so that he gradually begins to hate the one who wanted only good. Instead of caring for parents who lose their independence with love, children begin to look forward to the care of an elderly person and suffer from such thoughts themselves. This is very wrong, - says SOAR-certified therapist, psychologist Natalia Petrova. - Attention and visits of children may not be so frequent, but it is important that it is done with pleasure. It is better to hire a professional or transfer to a boarding house, where in addition to proper care there will be competent medical and psychological assistance and society. At the same time to love, to come, but to save your life and family than to wait for the death of a loved one, without confessing to yourself".

When dealing with the elderly, it is necessary to minimize personal losses, which will save energy and preserve health.

The new Russian private boarding houses have experienced psychologists who work not only with older parents, but also with their adult children. They have something to tell on this topic from their own practice. Elena Ivanova has been working in Senior Group boarding houses for five years, she advises:" it is Important that relatives are not afraid to talk about their feelings", because it is easier to work with people who openly Express their fears and doubts. They understand that there is an internal conflict and it is necessary to solve the urgent problem. Elena agrees that doubts can not be left unanswered: they are detrimental to both children and elderly relatives (even those who are in a deep stage of dementia, still feel the mood of loved ones)....If you sent your parents, grandmother, grandfather, uncle, aunt, wife, husband to a boarding house for the elderly - it does not mean that you abandoned them! You keep taking care, just in a different form. In particular, to maintain the strength to earn and provide elderly relatives with decent care" [2]. 


\section{Gender dimension of the problem}

Despite the fact that technically in the generation of "sandwich" can be anyone, in practice it is still a gender-related problem: the care of elderly relatives and children is still most often borne by women. "Such challenges are faced by both men and women: households, families. But if there are women in a particular family, they bear the main burden of direct care and care practices. Because in our society it is believed that women can very effectively cope with such tasks, that they are so educated that this is their purpose. ...Caring practices in Russia are still heavily feminized, ... society is not modern enough. There are stable - one might even say Patriarchal - traditions that hinder the development of human potential. And society imposes these traditional norms on all its citizens" [17].

The Russian "sandwich" generation, which mainly consists of women 45-65 years old, was the subject of research by sociologists from the European University in St. Petersburg (co-coordinator of the program of gender studies, Professor of the faculty of political Sciences and sociology Elena Zdravomyslova). Professor E. Zdravomyslova notes that when the question arises, who should take care of children and sick relatives of the family, most often the career of men try not to limit, so these responsibilities fall overwhelmingly on women: "Her inhibition in the workplace is not so destructive for her personally or for all. The woman agrees to this lighter load" [18].

"If the family consists of men and women, the division of labor for the care of an elderly person are trying to organize so that everyone contributes. But with this division of labor which is very helpful! - we still see that the main figure in the organization of care is a woman. It distributes responsibilities and assumes primary responsibility. And men perform a number of functions related to physical effort: for example, to move an elderly person to the bath, to bring something heavy, to provide the household with food. All they do. But primary care has a woman's face. ... We maintain in many ways such a gender way of life, when the care of the weak in the family falls on the woman. At the same time, society does not think that caring for a sick person, even relatives, is a huge work. Many of our informants say that they become locked in their own home: do not go out, do not relax, do not talk. ...And if you have to take care of your mother-in-law, who has been gnawing at you all your life, or a drunkard-test? ...Although some women are glad that they have the opportunity to take care of relatives, others said that it is hard for them, and some - that they are in despair" [18].

Against the background of the ongoing demographic modernization - the liberalization of marriage and the emancipation of women - in Russia are still popular ideas about the family purpose of women, as noted by the Junior researcher of the Laboratory of comparative studies of mass consciousness of the HSE Margarita Fabrikant [16]. Self-realization of women as mothers and wives is the priority of the family before work. "A woman is trapped, especially if there is no man in the house," said Olga Isupova, senior researcher at the HSE Institute of demography. She or is compelled to work as-that partially, or to leave work, as a result of money becomes less and less, the family begins to live on any grants or savings, opportunities to take the nurse disappear. And if no one helps at the level of the state-society, the situation is quite complicated. At the same time, if a person takes care of their parents or relatives, all perceive it as the norm. Like, well, it should be the same" [16].

What if your elderly relative needs more care than you can provide?

In Russian society, it is not accepted to delegate the care of the older generation to any structures. "The sandwich generation syndrome turns out to be extremely tough, because we have little institutional support for the balance of roles and obligations that society puts before a person, and the person himself - in front of himself" [17].

of course, families are different. There are different needs for care, and the amount of available resources and opportunities. Quite often caring people are looking for a division of labor and assistants. These assistants can be family members, employees, and social workers. People who are better off use these resources to ease the burden of care. 
And yet it's mostly not widespread. First, because it is relatively expensive: not all families can afford it. Secondly, because there is a lot of moralizing about the "family debt". Why in this family do not care for the elderly properly: are they bad children of their parents? Third, because of distrust of market institutions. Who can guarantee that this nurse will not do something wrong? This distrust is also due to the fact that there is a mismatch between the practices of care and the needs of care, that is, what an elderly person wants, what he used to: for example, that he is not just fed-changed clothes, but also talked to him, hugged-kissed. An employee may not be able to perform the amount of care expected of him or her. He performs primarily instrumental tasks: it is necessary to make an injection - made. Fed, changed clothes - all this is very good. But an older person who is being cared for may lack his or her involvement: can we talk? and listen?

In this situation, there are several points that are extremely important. First, it is necessary to make a decision on how to organize care - to move in or live separately. According to the polls, it was easier for those who did not move in. The majority of respondents agreed that living together with a sick, albeit very beloved, native person is a difficult test. It is better to live nearby or even to go to the other end of the city, to come up with any options, but not to live together.

Secondly, those families who had the opportunity for a while (two or three weeks) to place a loved one in a boarding house with geriatric care, coped better. The opportunity to relax and improve the condition of a relative significantly reduced tension in the family. At the same time, studies of doctors and psychologists confirm that the most prosperous old age is at home, not in others. Well if there is an opportunity to use paid services of assistants in the house.

By the way, "some informants (who had money) chose to live in a boarding house, but in one where the quality of services and accommodation are at a decent level. They did not want to move to the children, first to be a servant, and then become a burden" [20].

In our society, it is necessary to change the situation so as to relieve the representatives of the core generation, faced with the "sandwich syndrome", with the help of market services, social workers, volunteers.

There are such services all over the world. And if you look at the number of people who need help, then about every person who is not able to serve themselves completely, in need of a hospital, there are still four or five people who are at home and who need help at home. In Moscow, there are several hundred thousand people, and if we are talking about Russia as a whole, it is about 3 million people who need help and who can be helped.

Free assistance at home can be obtained not only in the social service Center - you can also use the services of other companies at no cost. On January 1,2015, new rules of social services came into force in Russia. Now this system includes commercial and non-profit organizations that can provide such services free of charge for those categories of citizens who are entitled to free service.

One of the most prominent representatives of such service providers is Senior Group company, which works with the support of the Department of labor and social protection. Her social service "Assistant" is a free help to elderly people at home. For 10 years of work the company has more than 500 wards. The General Director of the company Alexey Sidnev believes that if you systematically and systematically approach the provision of patronage services, you can achieve good results and make the life of an elderly person better. "Social workers do not take on complex cases, because they can not provide medical services, and we can. We have nurses, and where there are difficult cases, we will always help. Our company pays much attention to training, we have first-class technologies, we track where our employee was, how and what services he provided. Quality, and it at us at high level, we control honestly: through calls, sudden visits, by means of an independent assessment. In our work we use modern international approaches, cooperate with Israelis, French, Finns, and what they teach us, we teach everyone 
who works for us. We even have cases when people come to us to work from social institutions, because we give the opportunity to work flexibly. In our company you work more-you get more. Moreover, many already understand that the state will gradually move away from the provision of services, and will order and control them" [2].

If a person begins dementia and relatives see it, you need to understand that dementia can not be cured. Alzheimer's disease can not be cured either, but you can change the course of the disease. And for this you need to do special exercises, such as writing a diary every day, read aloud together, tell some historical stories, develop sensory and fine motor skills of hands. This, of course, gives positive results. Often, children cannot force or encourage their parents to do so, especially since they are not experts in the field. Then comes to the aid of a specialist who knows and knows how, with a suitcase in which the game, and bags for the development of fine motor skills of hands, and a lot of things necessary for training. Unfortunately, the state does not do this yet, but it is very much in demand and, most importantly, useful, because it helps to improve the quality of life of older people, and the longer a person can be independent, the better.

Does the «sandwich» generation problem have a solution? Some, like Jane Gidden and Ellen Cole, see it as an effort to "not be a burden to their own children": "Knowing how much effort it takes to take care of us at our age, we seventy-year-olds buy long-term health insurance, choose smaller homes so that our children don't have to deal with our fractures, explore home care options, look at nursing homes and social housing for the elderly, choosing what will more suit our needs and tastes, when the time comes" [14].

Others believe that it is necessary to change the attitude to care for the elderly in General: in Russia still dominates the idea that elderly parents should take care of their children, while in Western countries it is not so, which, of course, does not negate the need for care and attention to older relatives. As a result, the system of care for the elderly is also changing: nursing homes in the US and Russia are now at very different levels [18].

of course, to condemn those who are satisfied with their relatives in institutions, not: for many it's a terrible moral dilemma, because, on the one hand, the conditions there are worse than ever, and on the other - other options often are no physically. However, if it is possible to find a normal place or a decent nurse, this will not be anything terrible, especially since not everyone has sufficient physical strength, for example, to cope with bedridden patients.

\section{Conclusion}

According to statistics, $30 \%$ of 80 -year-olds suffer from dementia disorders. At the same time, according to the forecast of Rosstat, in 10 years the representatives of this age category in Russia will be 2 times more. So, the problems of caring for the elderly will affect many families. And the upcoming increase in the retirement age, as we noted earlier, will only further aggravate the already difficult life of the domestic generation "sandwich".

Nevertheless, there have been some positive developments in this area. First of all, the attention to the problem is growing in the country. Market mechanisms, more precisely, the private sector, contribute to the modernization of care for the elderly. There are private pensions, however, while they are not enough and they are not cheap. The market for care services for the elderly is developing, albeit in a large part of the shadow, with the use of migrant labour. The Institute of volunteers and social assistants is actively growing. All this suggests that society is undoubtedly changing.

Sandwich generation syndrome cannot be defeated or overcome, but it can and should be alleviated. In any case, whatever the solution to the problem, it is worth starting to pay attention to it and recognize that in the near future the sandwich generation will only grow.

\section{References}

1. Alferova I.A. Peculiarities of Psychological Problems of Elderly People // Contemporary Problems of Social Work. Vol. 3. 2017. No. 3 (11). P. 147-153. 
2. "Assistant" in service. URL: https://home.seniorgroup.ru/.

3. Bagrova N.V., Papkova N.E. Problems of Social-Psychological Adaptation of Elderly People and Methods of Their Overcoming // Contemporary Problems of Social Work. Vol. 4. 2018. No. 3 (15). P. 65-73.

4. Breev B.D. On the issue of population aging and depopulation // SOCIS. 2008. No. 2. P. 6263.

5. «Hidden army» of grandparents helping families priced out of childcare. URL: https:// www.theguardian.com/uk-news/2014/jul/08/grandparents-stop-work-support-familieschildcare-costs.

6. Kholostova E.I. Social work with older people: studies. Benefit. M.: Dashkov and Co, 2005.

7. Kholostova E.I., Egorov V.V., Rubtsov A.V. Social gerontology: studies. Benefit. M.: Dashkov and Co, 2005.

8. Mardakhayev L.V. Social pedagogy: a textbook for students supreme training institutions. M.: Publishing house RSSU, 2013. 416 p.

9. Miller D.A. The 'sandwich' generation: adult children of the aging. URL: https://www.jstor. org/stable/23712207?seq=1\#page_scan_tab_contents.

10. Papkova N.E., Bagrova N.V. Social and Pedagogical Aspects of the Problems of People of «Third Age» at the Present Stage // Contemporary Problems of Social Work. Vol. 4. 2018. No. 2 (14). P. 41-48.

11. Social pedagogy: a brief glossary of concepts and terms / ed.-comp. L.V. Mardahaev. M.: Izdvo RSSU, 2016. $364 \mathrm{p}$.

12. Strategy of action for senior citizens until 2025. URL: http://static.government.ru/media/ files.

13. Stuart-Hamilton J. Psychology of aging. St. Petersburg: Peter, 2002. 256 p.

14. The Club Sandwich Generation: Caregiving at 70. URL: https://www.huffingtonpost.com/ jane-giddan-and-ellen-cole/the-club-sandwich-generation-caregiving-at-70_b_6837688. html.

15. URL: http://www.demoscope.ru/weekly/2016/0677/gazeta031.php.

16. URL: https://iq.hse.ru/news/177666358.html.

17. URL: https://www.the-village.ru/village/people/city-news/232683-sandwich-generation.

18. Volyanova S. Should children take care of elderly parents and what will be their old age in the future? Sociologist Elena Zdravomyslova tells. URL: https://paperpaper.ru/campus/ zdravomyslova/.

19. Yatsimirskaya R.S., Belenkaya I.G. Social gerontology. M.: VLADOS, 2003.

20. Zdravomyslova E. "Sandwich syndrome". Family care for the elderly // Business Petersburg. 25.02.2016. URL: http://blog.dp.ru/post/8574/.

21. Zdravomyslova E. Why older people choose a nursing home // Business Petersburg. 17.02.2016. URL: http://blog.dp.ru/post/8535/.

\section{REFERENCE TO ARTICLE}

Papkova, N.E. (2018) Problems of «Sandwich» Generation: Psychological and Gender Aspects, Contemporary Problems of Social Work. Vol. 4. No. 4 (16). P. 46-52. DOI: 10.17922/24125466-2018-4-4-46-52 (International bibliographic description).

\section{CONTACT INFORMATION:}

Papkova Natalia Evgenievna

Expert of the Department of Scientific and Technical Information

Russian State Social University

Wilhelm Pieck, str. 4, build. 2

129226 Moscow, Russian Federation

E-mail: marova@inbox.ru 


\section{LABOUR PROTECTION}

\section{Nakhapetyan A.A.,}

orthopedic dentist, Heartman Clinic, Moscow;

postgraduate student, Moscow.

E-mail: aleks19.92@mail.ru

ORCID ID: orcid.org/0000-0002-4233-7408

\section{Erokhova V.V.,}

Landscape Architect - City Planner, Moscow.

E-mail: valeriya.e1@ mail.ru

ORCID ID: orcid.org/0000-0002-5748-1592

\section{Analysis of the Dynamies of Changes in the Elemental Composition of Ecosystems Under the Influence of Anthropogenic Activities}

Receiving date:

14.09.2018

\author{
Preprint date:
}

19.11.2018
Taking to print date:

18.12.2018

Annotation: at the present time in the world there is an increase in urban agglomeration and expansion of the boundaries of large cities. Examples of such extensions are ubiquitous, such as the idea of uniting Paris and its suburbs into a large metropolis, the so-called "Greater Paris". Similar changes occurred in the Moscow region, on July 1, 2012, a large district in the south-west of the city was annexed to the territory of Moscow. According to the results of the merger, the borders of Moscow expanded and the new administrative district of TINAO became part of the city. All these changes in the boundaries of large cities around the world are characterized by the concept of urbanization.

Urbanization is one of the major trends in modern land use [15]. In 2014, the share of urban population in the world was 54\%, and according to forecasts, by 2050 it is estimated that the number of urban dwellers will be about $66 \%$ of the total population of the planet, equal to about 6.3 billion people [9].

There is a huge variety of characteristics of urban districts in the world: about half of urban residents live in relatively small settlements, numbering less than 500,000 inhabitants, and almost one in eight live in 28 megacities with a population of 10 million or more. Since 1990, the number of megacities has almost tripled; and by 2030, 41 urban agglomerations are projected to contain at least 10 million inhabitants each [13].

Any change has its advantages and its problems. The advantages and advantages of urbanization include the development of infrastructure and the emergence of various social organizations, the development of new projects of cultural leisure and recreation, the emergence of new affordable housing for the population, as well as creating additional opportunities for migration of the population. The problem of urbanization can be attributed to the deterioration of the ecological characteristics of urbanized territories, migration of the 
population becomes unregulated, depletion of forest reserves, deterioration of soil fertility indicators and their functions in general [5].

At the moment, there are a large number of state programs on project solutions related to urbanization. In such programs, the scenario and trends of ongoing changes are envisaged; it is the choice of the most rational development scenario that will allow to carry out this process without deterioration of environmental indicators, as well as to maximally neutralize possible negative consequences [6].

A weighty negative consequence of the change in the process of urbanization is having on the soil. With the increase in population migration, there is a need to build places for housing and the creation of new jobs, which leads to mass development. This changes the soil characteristics and has a negative effect on the ecosystem services provided by the soils.

Currently, there is an acute problem of the ecological status of different regions of the world. The main centers of violation of a stable environmental situation are located in major cities of the world. In the course of his life, a person creates various benefits for the population. These include construction, industrial development, the development of air and auto equipment, the production of pharmaceuticals, mining and processing of minerals and much more. Despite attempts to reduce the destructive impact on the world around man, the ecological situation is aggravated every year. Now, in most countries of the world, in addition to creating a priority for reducing the impact on nature (ecological construction, preservation of natural massifs, restriction in logging, etc.), there are organizations that are responsible for environmental monitoring. Organizations for environmental monitoring put forward certain standards for the impact on various systems of the biosphere and monitor their compliance. However, these standards only reduce the speed of the changes. Changes under the influence of human activity can cause irreversible effects.

At first glance, insignificant emissions during construction, transport, agrarian / industrial sectors, etc. Do not exceed the performance standards of various ecosystems. However, this is the direction of changing their elemental composition.

On the example of this study, the main criteria for changing the elemental composition of soil ecosystems are displayed, and the dynamics of their change in perspective are also presented.

Key words: ecosystems, urbanization, elemental composition, dynamics.

JEL classification: J190, J280.

\section{Introduction}

Since, in the urban context, ecosystems are by definition highly modified and fragmented, their analysis is not limited to ecosystems per se, but includes specific ecosystem components related to the delivery of individual services [7].

Ecosystem services are defined as the benefits that people receive from ecosystem functions or the direct and indirect contribution of ecosystems to human well-being [13].

The loss of urban ecosystems can include high long-term economic costs and serious consequences for social, cultural and insurance values associated with ecosystem services [15]. The economic costs associated with the loss of urban ecosystems are due to the need to restore and preserve utilities and supplies through the built infrastructure, since the lost services provided by the urban green infrastructure are lost. Further negative consequences stem from the consequences in social and cultural values, including a sense of place, identity and community, social cohesion and local environmental knowledge.

Ecosystem services are environmental engines [11]. They are key to life support. Earth, water, air, climatic and genetic resources should be used rationally so that they can serve future generations.

This article discusses examples of changes in the elemental composition of soil ecosystems under the influence of human activities. The object of the study was chosen territory with a high degree of urbanization - the Trinity and Novomoskovsk administrative districts of Moscow. For six years (since 2012), about $84.5 \mathrm{~km}$ of new roads, 2 metro stations, about 10.4 million square meters of residential and 3.1 million square meters of commercial real estate, 15 park spaces were built on this territory. Despite the creation of a multifunctional space that is convenient for the inhabitants of the region, a destructive impact is being made on such a component of the biosphere as soil.

In the process of urbanization, deforestation occurs, a change in the type of land use of territories, an increase in emissions of chemical elements, pollution with solid household waste [1]. In the future, this affects not only the yield of the territory, but also the health of the population. 
In the course of life, a person consumes food products produced on the soil, subject to anthropogenic activities. From here there is an excess of various pollutants in products and a decrease in its vitamin and mineral composition [12]. Pollutants entering the groundwater through the soil are capable of causing a disturbance not only of the agro-industrial benefits, but also in the state of the region's water reserves.

The most balanced functioning of ecosystems ensures the proportional preservation and maintenance of ecosystem services [4]. A feature of natural ecosystems is the conservation of biological diversity, as well as the full production of ecosystem goods [8].

Ecosystem services affect different areas of human activity. Thus, among the ecosystem services there are 4 categories [2]. The first category - resource services, is responsible for ensuring the production of goods and services with the necessary natural resources [4]. The second category are regulatory services, they have a direct impact not only on the intraexchange ecosystem reactions, but also in combination with the other categories have an impact on the quality of atmospheric air and the state of human health. The relationship of changes in this service with human health is expressed in violations of the elemental composition of the soil, water, air, which, in aggregate, violates the elemental composition of human food [12]. The main objectives of the benefits derived from regulatory services, is the regulation of the microclimate, reserves and water purification, as well as possible diseases of plants, animals and humans.

Important for the functioning of ecosystems and human life is a cultural service, which is responsible for the development of spiritual enrichment among the population, cognitive activity, etc. [1]. With a lack of socially significant objects in the environment of life, a person may experience changes in the state of psychological health, which, as a result, affects the physiological state.

To identify the dynamics of changes in the elemental composition of soil systems, it is necessary to study the changes affecting all ecosystem services in aggregate.

Methods to create an idea of the dynamics of change, it is necessary to analyze the existing soil indicators. For this, the main methods of work were formulated (table 1).

Table 1

Methods and stages of research

\begin{tabular}{|c|l|l|l|}
\hline Stage & \multicolumn{1}{|c|}{ Method } & \multicolumn{1}{|c|}{ Subject / object } & \multicolumn{1}{c|}{ Expected results } \\
\hline 1 & $\begin{array}{l}\text { Reconnais- } \\
\text { sance }\end{array}$ & Digitization of maps & $\begin{array}{l}\text { Identification of zones subject to urbanization (de- } \\
\text { termination of soil sampling zones) }\end{array}$ \\
\hline 2 & $\begin{array}{l}\text { Work on } \\
\text { the object }\end{array}$ & Field survey, sampling & $\begin{array}{l}\text { Morphological description of the soil, sampling to } \\
\text { identify the physical and chemical soil characteristics }\end{array}$ \\
\hline 3 & $\begin{array}{l}\text { Laboratory } \\
\text { research }\end{array}$ & $\begin{array}{l}\text { Conducting experiments on } \\
\text { the basis of the natural sci- } \\
\text { ence laboratory of the RSSU }\end{array}$ & $\begin{array}{l}\text { Determination of fluorine, phosphorus, carbon, ni- } \\
\text { trate, exchangeable ammonium nitrogen, pH and } \\
\text { density }\end{array}$ \\
\hline 4 & $\begin{array}{l}\text { Results } \\
\text { Analytics }\end{array}$ & $\begin{array}{l}\text { Work with the results of } \\
\text { the third stage and literary } \\
\text { sources }\end{array}$ & $\begin{array}{l}\text { Forecast of changes in the elemental composition } \\
\text { of ecosystems }\end{array}$ \\
\hline
\end{tabular}

As presented in the table, 4 main stages of work were highlighted. In the course of stages $1-3$, data were obtained showing the state of the soil in the identified typical zones. Since the urbanization process is gaining momentum in this region, at the fourth stage, an assessment of the dynamics of possible changes in the elemental composition was presented. It is based on the growth trend of the existing urbanization and the approved plan for the development of the territory by a complex of urban planning policy and the construction of the city of Moscow. 


\section{Results}

At the first stage, during the digitization of maps, the main types of territories were identified at the object of study. After analyzing the changes in the areas, conclusions were drawn up, on the basis of which further research was carried out (table 2).

Table 2

Types and characteristics of territories

\begin{tabular}{|l|l|l|}
\hline $\begin{array}{l}\text { Type of } \\
\text { territory }\end{array}$ & \multicolumn{1}{|c|}{ Indicators } & \multicolumn{1}{c|}{ Sphere of influence } \\
\hline forest & $\begin{array}{l}\text { Reduction of forest area } \\
\text { from } 84.4 \text { thousand hectares } \\
\text { to } 68.47 \text { thousand hectares }\end{array}$ & $\begin{array}{l}\text { Impact on air circulation and ecosystem microclimate, chang- } \\
\text { es in soil horizons A, AB when approaching urbanized zones }\end{array}$ \\
\hline $\begin{array}{l}\text { arable } \\
\text { land }\end{array}$ & $\begin{array}{l}\text { Reduction of arable land } \\
\text { from } 38.8 \text { thousand hectares } \\
\text { to 24.32 thousand hectares }\end{array}$ & $\begin{array}{l}\text { Reduction of cultivated areas, reduction of renewable indica- } \\
\text { tors and feeding of soils due to agricultural engineering }\end{array}$ \\
\hline $\begin{array}{l}\text { recre- } \\
\text { ational }\end{array}$ & $\begin{array}{l}\text { The increase in the number } \\
\text { of park spaces, the emer- } \\
\text { gence of 15 new parks }\end{array}$ & $\begin{array}{l}\text { Improving the ecological status of the three abandoned areas } \\
\text { through the creation of "green" spaces, sealing about 10\% of } \\
\text { the area of parks and squares of 12 parks (formerly forest and } \\
\text { arable lands) }\end{array}$ \\
\hline $\begin{array}{l}\text { residen- } \\
\text { tial (cot- } \\
\text { tage) }\end{array}$ & $\begin{array}{l}\text { The emergence of villages } \\
\text { private households, an in- } \\
\text { crease in their area from } \\
\text { 0.54 thousand hectares to } \\
\text { 9.7 thousand hectares }\end{array}$ & $\begin{array}{l}\text { Negative: deforestation, disturbance of soil metabolic pro- } \\
\text { cesses, littering of the territory } \\
\text { Positive: the creation of residential areas (cultural ecosystem } \\
\text { service), the preservation of “green" areas (home ownership, } \\
\text { an average of 800 square meters per house) }\end{array}$ \\
\hline $\begin{array}{l}\text { resi- } \\
\text { dential } \\
\text { apart- } \\
\text { ment } \\
\text { building }\end{array}$ & $\begin{array}{l}\text { Mass building high-rise } \\
\text { buildings from } 0.54 \text { thou- } \\
\text { sand hectares to } 21.25 \text { thou- } \\
\text { sand hectares }\end{array}$ & $\begin{array}{l}\text { Negative: deforestation, violation of soil structures, clogging } \\
\text { of the lower soil layers due to the foundation, increasing pres- } \\
\text { sure on the soil } \\
\text { Positive: development of infrastructure, education for af- } \\
\text { fordable housing areas, development of cultural ecosystem } \\
\text { services }\end{array}$ \\
\hline
\end{tabular}

On the basis of the presented findings, 19 sampling points were determined, located when driving south along the Kaluzhskoye Highway (from the village of Kommunarka to the city of Troitsk). Points 1-9 were selected in residential areas (1-5 multi-storey buildings, $6-9$ cottage), points $10-13$ in areas of modern arable land (points 10-11 former forests, points $12-13$ arable since 1978), points 14-17 - forest zones, and points 18-19 recreational zones (18 - former forest territory, 19 - former solid waste storage).

At the second stage of work, visits to the site were carried out and soil samples were selected. After preparing the soil and the morphological description, the average density of the surface horizons $(0-10 \mathrm{~cm})$ of the soil of each sample was determined (table 3$)$.

Table 3

\section{Average density}

\begin{tabular}{|c|c|l|}
\hline No Point & Indicator & \multicolumn{1}{c|}{ Evaluation } \\
\hline $1-5$ & 1,62 & There is a strong soil compaction \\
\hline $6-9$ & 1,21 & Soils of a high degree of compaction \\
\hline $10-11$ & 1,01 & Indicators in the normal range \\
\hline $12-13$ & 1,06 & Indicators in the normal range \\
\hline $14-17$ & 0,85 & Indicators in the normal range \\
\hline 18 & 1,11 & Indicators in the normal range \\
\hline 19 & 1,18 & $\begin{array}{l}\text { Restoration of normal indicators of soil density, due to the creation of } \\
\text { recreational zones }\end{array}$ \\
\hline
\end{tabular}


Soil compaction can adversely affect many of the functions of ecosystem services. One of the main impaired functions is water absorption and water exchange capacity. This can change the elemental composition of the ecosystem as a whole.

At the third stage, the main indicators of the components of the ecosystem were calculated (table 4).

Table 4

Average of each point

\begin{tabular}{|c|c|c|c|c|c|c|}
\hline Field & $\mathbf{p H}$ & Humus & Nitrates & $\begin{array}{c}\text { Ammonium } \\
\text { Nitrogen }\end{array}$ & Phosphorus & Potassium \\
\hline $1-5$ & 3,96 & 2,43 & 5,63 & 1,05 & 79,23 & 118,4 \\
\hline $6-9$ & 5,23 & 3,94 & 7,59 & 2,11 & 119,9 & 169,0 \\
\hline $10-11$ & 4,36 & 5,1 & 19,94 & 2,2 & 106,25 & 155,0 \\
\hline $12-13$ & 4,85 & 4,9 & 19,6 & 2,57 & 106,32 & 107,9 \\
\hline $14-17$ & 5,06 & 4,1 & 12,05 & 2,45 & 142,83 & 224,8 \\
\hline 18 & 5,01 & 4,8 & 11,20 & 2,65 & 189,32 & 225,01 \\
\hline 19 & 5,98 & 4,9 & 11,32 & 2,81 & 185,62 & 222,96 \\
\hline Standard & 6,39 & 6,47 & 20,1 & 3,74 & 236 & 226,13 \\
\hline
\end{tabular}

Based on the data presented, it is clear that an increase in the density of urbanization, in this case an increase in the number of residential zones, leads to a deviation from the norm. Consequently, this leads to a change in the elemental composition.

At the fourth stage of the work, the main consequences of the change in the elemental composition of the soil were identified (table 5).

Table 5

\begin{tabular}{|l|l|l|}
\hline Type of influence & \multicolumn{1}{|c|}{ Type Information } & \multicolumn{1}{|c|}{ Effects } \\
\hline Carbon reduction & Soil dehumination & $\begin{array}{l}\text { The change in the elemental composition of the ecosys- } \\
\text { tem, the violation of the normal conditions of growth of } \\
\text { plants, reducing the possibility of growing products }\end{array}$ \\
\hline Acidity & $\begin{array}{l}\text { There is a decrease in } \\
\text { acidity }\end{array}$ & $\begin{array}{l}\text { Violation of the nutritional abilities of plants, impaired } \\
\text { water exchange properties of the soil }\end{array}$ \\
\hline $\begin{array}{l}\text { Soil pollution dur- } \\
\text { ing construction } \\
\text { and life }\end{array}$ & $\begin{array}{l}\text { Anthropogenic inclu- } \\
\text { sions }\end{array}$ & $\begin{array}{l}\text { Violation of soil structures, mixing soil horizons, viola- } \\
\text { tion of soil processes and changes in the elemental } \\
\text { composition }\end{array}$ \\
\hline $\begin{array}{l}\text { Decrease in the } \\
\text { main indicators }\end{array}$ & $\begin{array}{l}\text { Nitrates, phosphorus, } \\
\text { potassium, ammonium } \\
\text { nitrogen }\end{array}$ & $\begin{array}{l}\text { Deviation from the norm confirms the variability of the } \\
\text { elemental composition }\end{array}$ \\
\hline
\end{tabular}

\section{Conclusion}

This paper presents the main methods that reflect the choice of research. $0 \mathrm{n}$ the basis of the obtained results and intermediate conclusions, it was shown that in the course of urbanization of varying degrees, deviation of soil characteristics from the norm occurs.

Despite the fact that many indicators are within the normal range, the tendency to decrease is confirmed. This confirms the fact of the variability of the elemental composition of the ecosystem under the influence of anthropogenic factors.

A change in the elemental composition can lead to a disruption in the functioning of the soil, and therefore to a disruption in the functioning of ecosystems. With the inability of the ecosystem to produce benefits, the population may experience a number of gaps: from food issues to changes in health status. 


\section{References}

1. Alaimo K., Packnett E., Miles R., Kruger D. Fruit and Vegetable Intake among Urban Community Gardeners // Journal of Nutrition Education and Behavior. 2008.

2. Alcamo J. Ecosystems and human wellbeing: a framework for assessment // Millennium Ecosystem Assessment. World Resources Institute, Washington, DC, 2005.

3. Babkina A.A. Application of the Snow-Indication Method Under Anthropogenic Load Conditions // Contemporary Problems of Social Work. Vol. 3. 2017. No. 3 (11). P. 154-162.

4. Daily G.C. Introduction: What are ecosystem services? In: Nature's Services: Societal // Dependence on Natural Ecosystems. Island Press, Washington, DC, 1997.

5. Izzari M. Spatial modelling of potential landscape quality // Applied Geography 31, 108-118. 2011.

6. Lammert M., Allan J. Environmental auditing: assessing biotic integrity of streams: effects of scale in measuring the influence of land use/cover and habitat structure on sh and macroinvertebrates // Environ Manag 23(2): 257-270. 1999.

7. Martellozzo F., Landry J.-S., Plouffe D. et al. Urban agriculture: a global analysis of the space constraint to meet urban vegetable demand // Environ Res Lett 9:064025. 2014.

8. McGranahan G., Marcotullio P. Urban Systems Coordinating. Ecosystems and Human Wellbeing: Current State and Trends // Millennium Ecosystem Assessment. 2015.

9. Meier T., Christen 0. Environmental impacts of dietary recommendations and dietary styles: Germany as an example //Environ Sci Technol 47:877-88.2013. 8

10. Mishustin S.S. State Regulation of Forestry As an Element of Environmental Safety of Moscow Region // Contemporary Problems of Social Work. Vol. 2. 2016. No. 2 (6). P. 177-184.

11. Pataki D.E., Carreiro M.M., Cherrier J. et al. Coupling biogeochemical cycles in urban environments: ecosystem services, green solutions, and misconceptions // Ecol Soc Am 9: 27-36. 2011.

12. Pickett J.A. Cis-Jasmone as an allelopathic agent through plant defence induction / J.A. Pickett, M.A. Birkett, T.J.A. Bruce, K. Chamberlain, R. Gordon-Weeks, M.C. Matthes, C.B. Moraes, J.A. Napier, L.E. Smart, L.J. Wadhams, C.M. Woodcock, 2011.

13. Sanye-Mengual E., Cerón-Palma I., Oliver-Solà J., et al. Environmental analysis of the logistics of agricultural products from roof top greenhouses in Mediterranean urban areas // JSciFood Agric 100-109. 2012.

14. Sun Y., Zhou Q., Xie X., Liu R. Spatial, sources and risk assessment of heavy metal contamination of urban soils in typical regions of Shenyang, China. J Hazard Mater 174: 455-462. 2010.

15. Vizzari M., Sigura M. Urban-rural gradient detection using multivariate spatial analysis and landscape metrics // Journal of Agricultural Engineering XLIV 91(1), 453-459. 2013.

16. Zubkova V.M., Voskresenskaya 0.L., Gaponenko A.V., Zubkov N.V., Belozubova N.Y. The accumulation and distribution of heavy metals in crop plants at different levels of soil contamination // International Journal of Ecology and Development. Vol. 31. Issue 2. 2016. P. 1-9.

\section{REFERENCE TO ARTICLE}

Nakhapetyan, A.A. \& Erokhova, V.V. (2018) Analysis of the Dynamics of Changes in the Elemental Composition of Ecosystems Under the Influence of Anthropogenic Activities, Contemporary Problems of Social Work. Vol. 4. No. 4 (16). P. 53-58. D0I: 10.17922/24125466-2018-4-4-53-58 (International bibliographic description).

\section{CONTACT INFORMATION:}

Nakhapetyan Alexey Andranikovich

Orthopedic Dentist, Heartman Clinic

Postgraduate student

Myasnitskaya str., 19

101000 Moscow, Russian Federation

E-mail: aleks19.92@mail.ru

Erokhova Valeria Vladislavovna

Landscape Architect - City Planner

Podolskoye Highway, 8

115093 Moscow, Russian Federation

E-mail: valeriya.e1@mail.ru 


\section{SPECIAL COLUMN}

\section{Delis Sevila Rodríguez,}

Ing., Profesor Asistente, Universidad de Guantánamo, Cuba.

E-mail: delissr@cug.co.cu

\section{Alberto Turro Breff,}

Dr.C., Profesor Titular, Universidad de Guantánamo, Cuba.

E-mail: aturrob@cug.co.cu

\section{Jorge Olivares Boada,}

Ms.C., Profesor Auxiliar, Universidad de Guantánamo, Cuba.

E-mail: jorgeab@cug.co.cu

\section{METODOLOGÍA PARA LA GESTIÓN UNIVERSITARIA CON ENFOQUE PROSPECTIVO EN LA INTEGRACIÓN DE LA EDUCACIÓN SUPERIOR EN GUANTÁNAMO}

Methodology for University Management with Prospective Approach in the Integration of Higher Education in Guantánamo

$\begin{array}{ccc}\text { Receiving date: } & \text { Preprint date: } & \text { Taking to print date: } \\ \text { 20.09.2018 } & 19.11 .2018 & 18.12 .2018\end{array}$

Resumen: El proceso de integración de la Educación Superior en la provincia de Guantánamo, ha permitido la unificación de diferentes factores estructurales que han tributado a la implementación de los Lineamientos de la Política Económica y Social del Partido y la Revolución, en particular la prioridad número 11 «La reorganización de los Sistemas de Educación, Salud, Cultura y Deportes, con un uso racional de los recursos, asegurando la calidad de estos servicios». En la presente investigación se utiliza el método prospectivo para desarrollar el proceso de gestión universitaria vinculado al proceso de planificación estratégica de la universidad integrada.

Annotation: the integration process of Higher Education in Guantanamo province has allowed the unification of different structural factors that have taxed the implementation of the Guidelines of the Economic and Social Policy of the Party and Revolution, particularly priority number 11 "The reorganization of the Education, Health, Culture and Sports Systems, with a rational use of resources, ensuring the quality of these services". In the present research the prospective method is used to develop the university management 
process linked to the strategic planning process of the integrated university.

Palabras clave: gestión universitaria, proceso de integración de la Educación Superior en Guantánamo, enfoque prospectivo.

Key words: university management, integration process of Higher Education in Guantanamo, prospective approach.

JEL classification: I200, I290.

\section{Introducción}

El proceso de integración en la Universidad de Guantánamo como nuevo proceder de la Educación Superior en Cuba, nos conlleva ineludiblemente a repensar en nuestra forma de actuar, de manera que seamos capaces de aportar importantes trasformaciones en correspondencia con las condiciones objetivas del momento histórico.

El enfoque prospectivo es una buena alternativa para dar respuesta a tan importante tarea pues constituye una disciplina para el análisis de sistemas sociales, que permite conocer mejor la situación presente, identificar tendencias futuras y analizar el impacto del desarrollo científico y tecnológico en la sociedad. Con ello se facilita el encuentro entre la oferta científica y tecnológica con las necesidades presentes y futuras de los mercados y de la sociedad. A la par, los ejercicios movilizan a los diferentes actores sociales para generar visiones compartidas de futuro, orientar políticas de largo plazo y tomar decisiones estratégicas en el presente, dadas las condiciones y las posibilidades locales, nacionales y globales.

La prospectiva se constituye así en un campo en plena evolución, de intersección entre los estudios del futuro, el análisis de políticas públicas y la planeación estratégica. Pero su propósito más amplio es promover un gran cambio cultural, una mejor comunicación, una interacción más fuerte y una más grande comprensión mutua entre los actores sociales para pensar en el futuro y tomar decisiones desde el presente (Gavigan, 2002).

La presente investigación constituye un significativo aporte al proceso de integración de la Educación Superior en la provincia de Guantánamo, ya que permite la unificación de los diferentes factores estructurales del proceso, particularmente con un enfoque prospectivo vinculado a la planificación estratégica de la universidad integrada, tributando a la implementación de los Lineamientos de la Política Económica y Social del Partido y la Revolución, en particular la prioridad número 11 «La reorganización de los Sistemas de Educación, Salud, Cultura y Deportes, con un uso racional de los recursos, asegurando la calidad de estos servicios», así como a otras acciones que desarrolla el Ministerio de Educación Superior en Cuba encaminada al logro de una universidad pertinente al desarrollo local (Alarcón, 2015, p. 1).

Desarrollar una Metodología para la gestión universitaria con enfoque prospectivo en la integración de la Educación Superior de Guantánamo, constituye el objetivo general de la investigación.

\section{Desarrollo}

El enfoque prospectivo de la gestión universitaria en el proceso de integración de los organismos formadores de la Educación Superior en la provincia de Guantánamo" constituye un significativo aporte al proceso, ya que permite la unificación de los diferentes factores estructurales del mismo, vinculado al proceso de Planificación Estratégica de la Universidad integrada y tributa a la implementación de los Lineamientos de la Política Económica y Social del Partido y la Revolución, en particular la prioridad número 11 «La reorganización de los Sistemas de Educación, Salud, Cultura y Deporte, con un uso racional de los recursos, asegurando la calidad de estos servicios».

Resulta novedoso, además, el empleo del enfoque sistémico para desarrollar el análisis estructural como herramienta teórico-metodológica, a través de la cual se investigan e identifican las variables estructurales del proceso de integración y se delimitan los factores motrices y explicativos del mismo, objetivos, los criterios de medidas y las estrategias maestras correspondientes. El análisis estructural y su combinación con las técnicas de prospectivas, 
conforman entre otras, un instrumento de análisis aplicable a las situaciones de complejidad e incertidumbre de los procesos de integración de Centros de Educación Superior en el territorio; con esta investigación se abre un camino que rebasa la etapa de diagnóstico, al establecer un instrumento analítico que permite planear estratégicamente éste proceso.

Se utilizaron, además, los resultados de investigadores nacionales e internacionales de la temática del Desarrollo Regional, así como el método dialéctico materialista e histórico. De forma particular, para explicar el sistema territorial a través del estudio interrelacionado de todos sus subsistemas y su relación con el entorno, se emplea el enfoque correspondiente a la Teoría General de Sistemas. El enfoque analítico estructural se utiliza como herramienta para el estudio de las relaciones entre las variables explicativas del crecimiento económico del territorio, cuya cuantificación se realiza a través del empleo de los modelos de ecuaciones estructurales.

El principal impacto alcanzado con la aplicación de este trabajo, está vinculado al logro de una mayor objetividad en los resultados del proceso de Planificación Estratégica, al producirse un incremento en el nivel de participación, sobre todo de los expertos y profesionales de las instituciones incluidas en el proceso de integración, vinculados con la planificación en la definición de los objetivos estratégicos, una adecuación de la estructura organizacional y de los sistemas de control de los procesos estratégicos, además de definirse los elementos estructurales cuya modificación es esencial para que el proceso de integración sea efectivo desde la proyección misma de la planificación estratégica y se consideran las diferentes perspectivas conque debe ser vista la misma en los procesos de integración de los Centros de Educación Superior (CES), se ha logrado una mejor efectividad en los planes, en un período que se ha caracterizado por la inestabilidad, complejidad e incertidumbre, propios de los procesos de integración, visto a través de los controles establecidos para su cumplimiento y la responsabilidad que se ha tenido al respecto.

En el desarrollo de la investigación se utilizaron Métodos Teóricos y Empíricos, incluyendo técnicas y herramientas de la Ingeniería Industrial y otras especialidades afines. El objetivo principal de esta integración o unificación presupone el incremento de la calidad, eficiencia, pertinencia e integración de la educación superior con la máxima racionalidad posible.

Evidentemente, este proceso de integración implica un rediseño organizacional que incluye la Proyección Estratégica de la Universidad Integrada visto como la meta a alcanzar y la búsqueda de la racionalidad en el empleo de los recursos de todo tipo, de manera que como una de las principales acciones desarrolladas en esta primera etapa fue la creación de grupos y comisiones de trabajo para acometer la compleja tarea con el objetivo de modelar a la Universidad Integrada, dando cumplimiento a las indicaciones recibidas del Ministerio de Educación Superior (MES) a partir de las directrices correspondientes, teniendo en cuenta las experiencias de otras provincias al respecto.

La Planificación Estratégica en el ámbito universitario, como vía para el perfeccionamiento de la dirección, constituye un proceso de carácter técnico mediante el cual se define, de forma participativa, la estrategia para el mediano plazo; en la actualidad se observan avances en los procesos de planeamiento estratégico que mejoran la calidad de los planes y el alcance de las metas.

Según Bertrand de Jouvenel 1964 uno de los pioneros de la prospectiva, hay dos maneras de comprender el futuro: como una unidad única o como una realidad múltiple. Lo que la entienden como la primera son los adivinos, aquellos que consideran que existe un destino que decide y marcan los hechos de la vida y son inmodificables. Los segundos consideran el futuro como una realidad múltiple, lo que implica que determinados hechos presentes pueden evolucionar de diversas maneras y presentarse de diferentes formas en el futuro: futuro posible o futurible, futuros probables o factibles y los futuros deseados, los dos últimos constituyen la visión organizacional.

Según Godet 1995 un directivo puede reaccionar de cuatro maneras diferentes frente al futuro: 
1. Con una estrategia pasiva. Dejar que las cosas ocurran. Al final lo que ocurrió es producto de la buena o mala suerte.

2. Con una estrategia reactiva: apaga fuego, el directivo que espera que ocurran los acontecimientos, espera a que otros actúen para copiar.

3. Con una estrategia prospectiva pre activa. Anticipa los acontecimientos y se prepara para el eventual acontecimiento de los hechos.

4. Con una estrategia proactiva: Aquella que previo análisis de escenarios alternativos ( 0 ; A; F; D), le permite definir un futuro posible y deseado ( visión) y las reglas de juego ( plan estratégico) para alcanzarlo. A diferencia de la previsión, se diseña una estrategia para actuar en busca de los deseado y posible.

Las diferentes herramientas utilizadas por los franceses en la Prospectiva Estratégica, con Michel Godet como fundador, han logrado estructurar toda una metodología con una serie de modelos que permiten de una manera secuencial y racional la identificación de futuros posibles y deseables.

Para facilitar la realización de la prospectiva en el proceso de planeación estratégica de la universidad integrada de Guantánamo se diseña una metodología que contiene los principales elementos de la "caja de herramienta prospectiva", en función de la tipología del problema a estudiar "integración efectiva de los centros de educación superior en Guantánamo: simulando el conjunto del proceso de la prospectiva estratégica que se muestra a continuación (ver fig. 1).

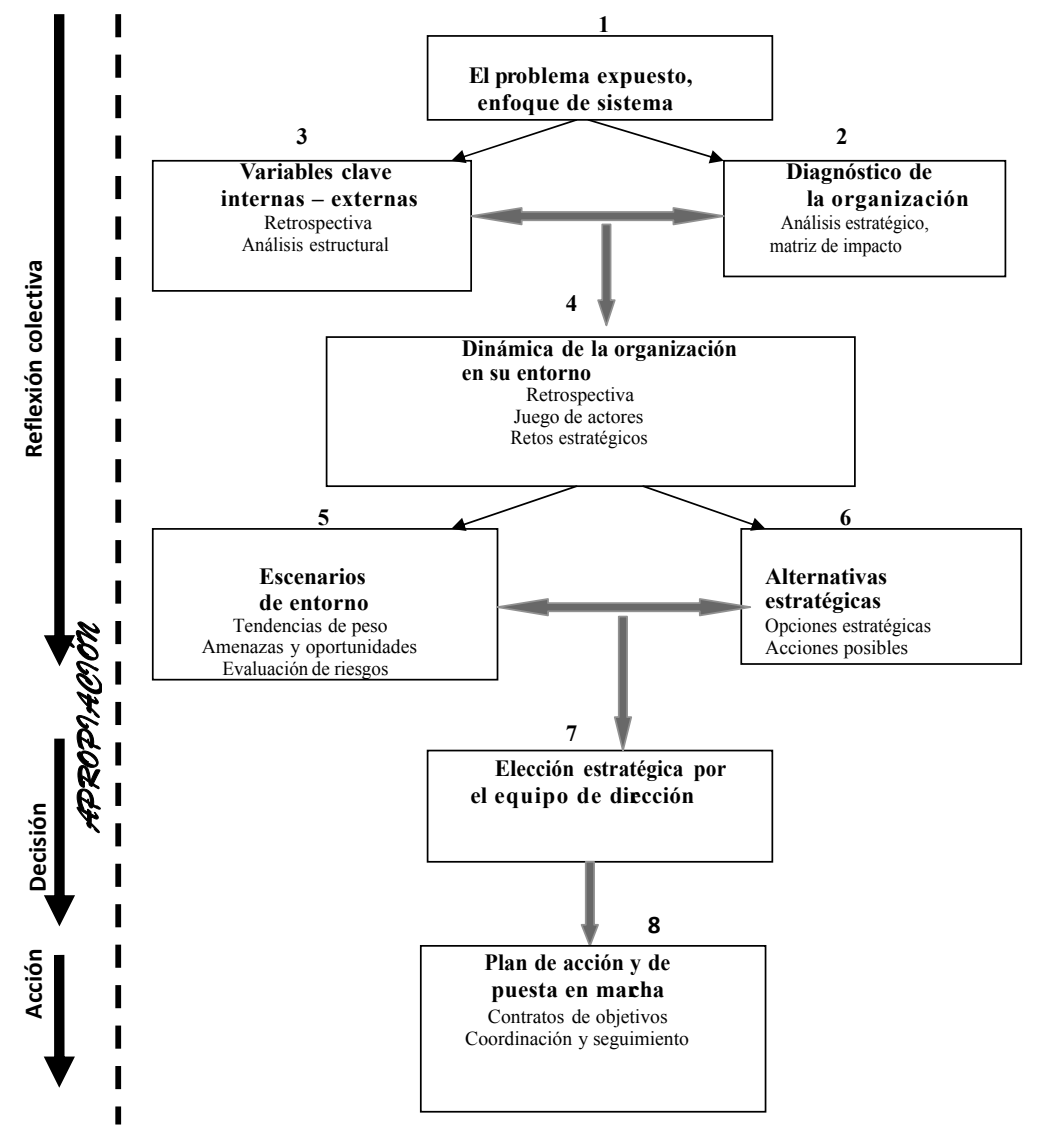

Figura 1. Metodología para la gestión universitaria con enfoque prospectivo en la integración de la Educación Superior en Guantánamo, adaptada al modelo de Michel Godet 


\section{Etapas que conforman la Metodología}

La primera etapa tiene por objetivo analizar mediante el enfoque de sistema el problema resolver y delimitar el sistema a estudiar. Se trata, en este momento, de situar el método prospectivo en su contexto socio-organizacional, a fin de iniciar el proceso con la formulación de la misión organizacional y los valores compartidos de la universidad.

La segunda etapa se basa en elaborar una radiografía completa de la universidad integrada desde el análisis de las funciones sustantivas con vista a identificar el balance interno (fortalezas y debilidades) y externo (oportunidades y amenazas), identificando el conjunto de factores de alcance estratégico.

La tercera etapa identifica las variables - clave de la organización y de su entorno con la ayuda del análisis estructural, identificando los factores claves de éxito.

La cuarta etapa intenta comprender la dinámica de la retrospectiva de la organización, de su entorno, de su evolución, de sus fuerzas y debilidades en relación a los principales actores de su entorno estratégico. El análisis de los campos de batalla y de los retos estratégicos permite descubrir las cuestiones clave para el futuro.

La quinta etapa busca reducir la incertidumbre que pesa sobre las cuestiones clave de futuro. Se utilizan eventualmente los métodos de encuesta a expertos, para poner en evidencia las tendencias de peso, los riesgos de ruptura y finalmente descubrir los escenarios de entorno más probables.

La sexta etapa pone en evidencia los proyectos coherentes, es decir, las opciones estratégicas compatibles a la vez con la misión y visión de la organización y con los escenarios más probables de su entorno. se consagra a la evaluación de las opciones estratégicas; con esta etapa finaliza la fase de reflexión previa antes de la decisión y la acción.

La séptima etapa es la elección de la estrategia, es la etapa crucial porque se trata de pasar de la reflexión a la decisión. Las apuestas estratégicas y la jerarquización de objetivos, resultado de la decisión del equipo de dirección.

La octava etapa se dedica enteramente a la puesta en marcha del plan de acción. Implica la negociación de objetivos (negociados o suscitados), la puesta en marcha de un sistema de coordinación y de seguimiento y también del desarrollo de una vigía estratégica (externa).

Debemos señalar que el desarrollo de esta metodología integrada, no tiene porque ser totalmente lineal. Comprende varios bucles de retroalimentación posibles, especialmente de la etapa 8 a la 4. La puesta en marcha de un plan de acción y los resultados de la vigía estratégica pueden conducir, en ciertos casos, a reconsiderar la dinámica de la organización en su entorno.

Desarrollo de la Metodología para la gestión universitaria con enfoque prospectivo en la integración de la Educación Superior en Guantánamo, adaptada al modelo de Michel Godet

Como parte del proceso de implementación de los Lineamientos de la Política Económica y Social del Partido y la Revolución, el Consejo de Ministros sesionado en diciembre de 2013 acordó extender a otras provincias el proceso de integración de las instituciones de educación superior pertenecientes al MINED, INDER y MES, que se había iniciado de forma experimental en las provincias de Mayabeque y Artemisa; así como en el municipio especial Isla de Juventud.

Evidentemente este proceso de integración implica que el mismo sea visto como un sistema por establecerse necesariamente un conjunto de relaciones de nuevo tipo que producen como efecto una serie de cualidades superiores a las de cualquiera de ellos de forma independiente, y es lo que da lugar al surgimiento de la Universidad Unificada.

Por consiguiente, al ser considerada la universidad como un sistema abierto, por encontrarse en constante interrelación (intercambio de elementos e información) con su entorno y dada la interacción permanente que se establece entre los sistemas social y técnico que los forman, 
es necesario concebir y gestionar a la Universidad Unificada como un sistema socio-técnico representada de la siguiente manera:

Proyección social Proyección económica Proyección política

\section{Entradas}

- Capital humano.

- Recursos financieros.

- Tecnología.

- Estudiantes.

- Información.

- Recursos materiales.

- Recursos energéticos.

- Otros.

Proyección territorial

ambiental

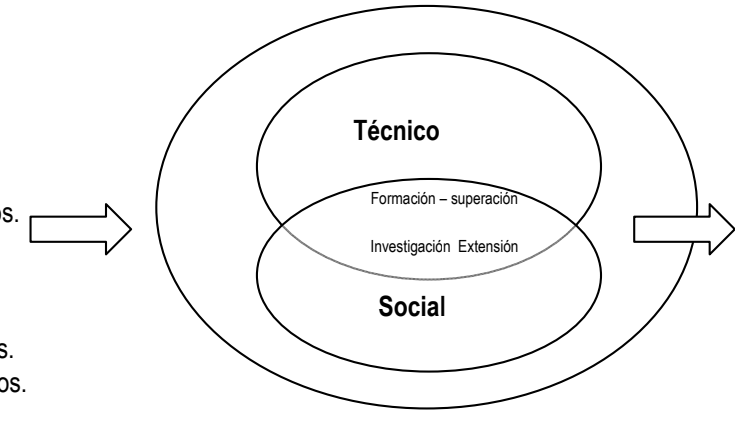

Principio: sistema abierto, Equifinalidad

\section{Salidas}

- Profesionales competentes.

- Claustro de excelencia.

- Proyectos de I+D+i

- Asesorías y consultorías.

- Actividades extensionistas.

- Otros servicios

educacionales y científicos-

Proyección

internacional

Figura 2. Representación de la Universidad Unificada como sistema socio-técnico

Para que sea efectivo dicho diseño debe considerar las exigencias que demanda la sociedad en la actualidad y a partir de las cuales realizar la proyección externa de la universidad unificada, lo que exige además analizar los requerimientos internos para responder con pertinencia a las mismas (proyección interna).

Para identificar los compromisos que se imponen a la universidad unificada y qué hacer para lograr su cumplimiento, es preciso contextualizar su modelo de gestión, de forma que el mismo sintetice las principales estrategias necesarias para las transformaciones que se requieren realizar en función de los objetivos propuestos en cada uno de los aspectos que forman parte de su ambiente externo e interno.

\section{Pasos seguidos:}

1. Presentación y análisis de la planeación de los tres centros.

2. Caracterización de la organización objeto de investigación; formulación de la Misión y valores compartidos, conceptualización y modos de actuación; diagnóstico estratégico (DAF0).

3. Prospectiva estratégica: Identificación de los factores claves de éxito; formulación de escenarios y Visión, análisis de actores; determinación de las Áreas de Resultados Claves (ARC).

4. Formulación de los objetivos estratégicos por ARC.

5. Estudio complementario de los objetivos estratégicos. Impacto en las ARC

6. Definición de Estrategias.

Presentamos a continuación la realización de la propuesta metodológica La gestión universitaria con enfoque prospectivo y sistémico en el proceso de integración de la Educación Superior en la provincia de Guantánamo, para la cual tuvimos en cuenta: enfoque de sistema, modelo socio técnico de gestión de la universidad unificada, la planeación estratégica de las tres entidades y la del Ministerio de Educación Superior, aplicación del método prospectivo en el proceso de planeación estratégica, además de la experiencia de los miembros de esta comisión.

Teniendo como premisas: diseño estratégico del Ministerio de Educación Superior (MES), los documentos recibidos para la unificación de las universidades, el diseño estratégico de los tres centros, un nivel de información mínimo necesario, Los resultados y aprobación de cada 
elemento del proceso estratégico en los talleres de planeación estratégica, el diseño de los instrumentales de la prospectiva estratégica en el proceso de planeación de la universidad integrada.

Diagnóstico estratégico en el proceso de integración de la universidad de Guantánamo

El diagnóstico estratégico se enfocó en el levantamiento del estado actual de las estrategias de las organizaciones objeto de estudio, la misma facilitó evaluar el comportamiento y alcance de los resultados que debían estar produciendo las estrategias definidas, la evaluación se resume en un listado de fortalezas y debilidades que de orden estructural, de procesos fueron analizadas y que sirvieron de base para evaluar las potencialidades de cambio y en especial de integración presentan los tres Centros de Educación Superior. Los resultados se muestran a continuación.

\section{Desarrollo del proceso estratégico de la universidad unificada.}

El desarrollo de la planificación estratégica de la universidad unificada estuvo guiado desde el primer momento de un modelo de cambio fundamental ver figura 3. Modelo de cambio fundamental, considerado como transcendental, de desarrollo y sostenible. Esto implica adoptar un enfoque en el cual se construya un futuro posible y deseado a partir de lo que resulta clave para lograr adaptación y crecimiento organizacional, lograr definir el deber ser de la universidad unificada resulta esencial en el manejo de la complejidad propio de los procesos de cambio estratégico y guía para corregir las desviaciones que pudieran aparecer en la gestión hacia ese cambio fundamental.

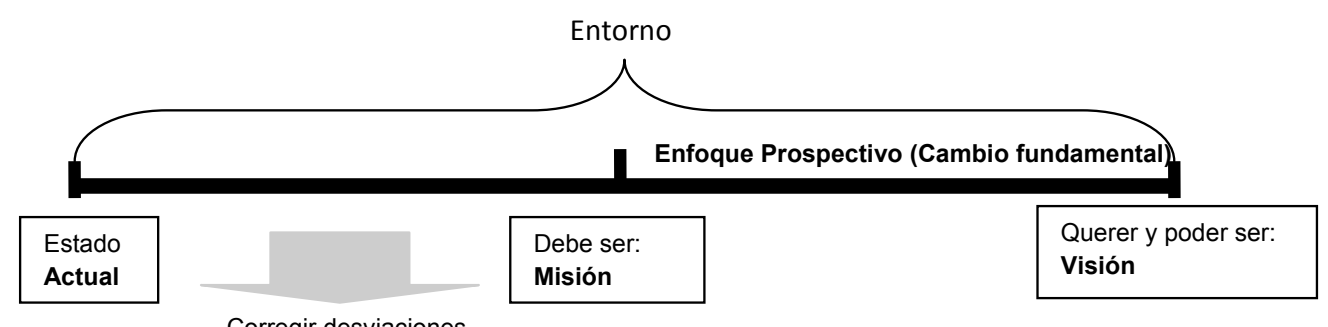

Corregir desviaciones

Establecimiento de la normalidad del sistema. Mantener el sistema en equilibrio

Figura 3. Modelo de cambio fundamental Universidad Unificada

El modelo de cambio fundamental fue escogido por su carácter sistémico y por los principios que le son propios al proceso de integración de la universidad de Guantánamo, en especial de equifinalidad y de ser un sistema abierto, este último principio establece que la universidad de Guantánamo elige el camino de cambio (fines) a seguir en dependencia de sus obligaciones y sus relaciones con el entorno que interactúa y por otro lado el principio de equifinalidad le favorece al elegir el mejor camino o línea de acción para alcanzar el fin elegido ( misión).

Tomando como referencia el modelo sistémico de cambio fundamental, se procedió a realizar la primera versión de la misión de la universidad integrada, guiada por las tres interrogantes siguientes:

- ¿Qué hacemos nosotros o debiéramos hacer que no puede ser hecho por ninguna otra institución en el territorio?

- ¿Qué necesidades sociales satisfacemos y a quién prestamos nuestros servicios en este territorio? 
- ¿Quiénes somos y para qué existimos los que trabajamos en nuestra Universidad cuando hay otros que se ocupan de la formación comunista de las nuevas generaciones en este territorio?

La respuesta a cada interrogante fue conformando el enunciado que constituye el objetivo supremo de la universidad unificada "Misión" , guía que nos indica en cada etapa del proceso estratégico la dirección y rumbo a seguir en el proceso de formulación, evaluación y selección de cada elementos que conformaron la planeación estratégica de la universidad unificada.

La prospectiva es, entonces en este contexto de integración de la universidad, una reflexión para iluminar la acción presente a la luz de los futuros posibles. Y es que los nuevos tiempos así lo exigen "cuando más alto es el árbol, mas pronto hay que plantarlo" (Godet, 1995).

\section{Cuadro 1. Matriz universidad unificada}

ENTORNO (MEDIO EXTERNO)

\section{OPORTUNIDADES (I)}

- Tendencia mundial a financiar proyectos.

- Incremento de la demanda de superación postgraduada.

- Posibilidades de alianza y convenios con otras instituciones y organismos.

- Existencia de convenios de colaboración internacional.

- Voluntad política para el incremento de proyectos de desarrollo local.

- Reconocimiento del papel de la universidad en las transformaciones económicas- sociales y medioambientales.

- Actualización del modelo económico.

- Unificación de las universidades del territorio.

- Posibilidad para ampliar la gama de carreras afines con el desarrollo del territorio.

\section{AMENAZAS (2)}

- Regulaciones que no favorecen el despliegue de proyectos de convenio de colaboración con el exterior.

- Contradicción de mecanismos económicosfinancieros que limitan el desarrollo exitoso de los procesos universitarios.

- Bloqueo económico y su impacto en la educación superior.

- Crisis económica financiera.

- Baja motivación de los jóvenes por los estudios universitarios.

- Incremento del financiamiento de la subversión ideológica.

- Preferencia de los jóvenes por la carrera de medicina.

DEBILIDADES (4)

- Inadecuada infraestructura física y tecnológica.

- Insuficiente producción científica de la comunidad universitaria.

- Insuficiente gestión de proyectos.

- Insuficiente calificación plantilla de cuadro

- Insuficiente impacto de la universidad en el desarrollo local.

- Insuficiente calificación de la plantilla de cuadros.

- Bajo por ciento de doctores.

- Insuficiente integración de los procesos universitarios.

- Insuficiente número de carreras acreditadas.

- Insuficiente trabajo de formación vocacional-orientación profesional.

- Insuficiente gama de carreras de interés territorial en la universidad. 
Para tal efecto es necesario adelantar previamente un diagnóstico estratégico. Como resultado del diagnóstico se logró una caracterización de las tres instituciones que se integran, tanto en lo interior y exterior, el siguiente (cuadro 1) resume los resultados de este ejercicio de identificación de factores o variables del sistema

\section{INTERNO (MEDIO INTERNO)}

La aplicación de la matriz DAF0 en su primera versión denominada en este caso Matriz de impacto, facilitó la identificación de las variables claves o factores estratégicos que actúan en el sistema con un carácter dinámico, el resultado de la aplicación de esta herramienta se muestra a continuación:

\section{DAF0 en su primera versión: Matriz de impacto}

La selección de las variables consideradas como estratégicas fueron escogidas por su impacto en la totalidad de la estructura del sistema, en el caso de los factores externos resultaron ser las siguientes.

\section{Factores externos (variables claves)}

Oportunidades: Incremento de la demanda de superación post-graduada; posibilidades de alianza y convenios con otras instituciones y organismos; existencia de convenios de colaboración internacional; reconocimiento del papel de la universidad en las transformaciones económicas- sociales y medioambientales; unificación de las universidades del territorio; posibilidad para ampliar la gama de carreras afines con el desarrollo del territorio.

Amenazas: Regulaciones que no favorecen el despliegue de proyectos de convenio de colaboración con el exterior; bloqueo económico y su impacto en la educación superior; crisis económica financiera; baja motivación de los jóvenes por los estudios universitarios.

\section{Factores internos (variables claves)}

Fortalezas: Claustro revolucionario y comprometido con el proyecto socialista cubano; creciente calificación científica - académica y por categoría docente del claustro; carrera Agronomía acreditada; se cuenta con la escuela de formación doctoral; actividad contablefinanciera confiable; contar con profesores de reconocido prestigio nacional e internacional; participación de la universidad en la gestión del desarrollo local mediante proyectos.

Debilidades: Inadecuada infraestructura física y tecnológica; insuficiente producción científica de la comunidad universitaria, insuficiente gestión de proyectos; insuficiente calificación de la plantilla de cuadros; bajo por ciento de doctores; insuficiente integración de los procesos universitarios; insuficiente número de carreras acreditadas; insuficiente trabajo de formación vocacional-orientación profesional.

Con las oportunidades y amenazas obtenidas se elabora la matriz de evaluación estratégica de los factores externos, con el objetivo de conocer la capacidad de respuesta de la Universidad ante el entorno, demostrándose que la capacidad de respuesta de la Universidad ante el entorno muestra una tendencia positiva, por lo que la universidad en su proceso de integración deberá fortalecer sus actividades y procesos para aprovechar las oportunidades frente a los problemas del entorno que imposibilitan el logro de buenos resultados en su gestión.

Con las fortalezas y debilidades obtenidas se elabora la matriz de evaluación estratégica de los factores internos, con el objetivo de conocer cuál es la capacidad de respuesta de la Universidad ante los factores internos, demostrándose que la capacidad de respuesta de la Universidad ante las fortalezas y las debilidades es de tendencia positiva, por lo que la universidad en su proceso de integración deberá continuar reforzando las fortalezas para influir en las debilidades que no dejan aprovechar las oportunidades.

La figura 4: grip radial de factores estratégicos, muestra de manera resumida los valores ponderados de cada perfil evaluado tanto en el ambiente externo como interno, lo relevante de cada variable o factor se muestra en la comparación y peso entre ellos, siendo en este caso los factores con mayor presencia dentro de las oportunidades y fortalezas, los que se muestra a continuación. 

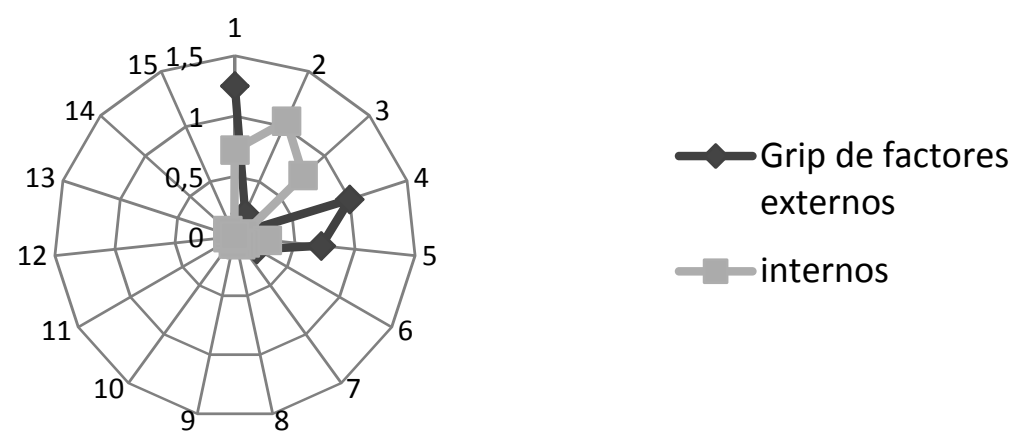
externos internos

Figura 4. Radial de factores externos / internos

Oportunidades relevantes: Incremento de la demanda de superación post-graduada; reconocimiento del papel de la universidad en las transformaciones económicas- sociales y medioambientales; unificación de las universidades del territorio.

Fortalezas importantes: Claustro revolucionario y comprometido con el proyecto socialista cubano; creciente calificación científica - académica y por categoría docente del claustro; carrera Agronomía acreditada.

La utilización de los recursos y resultados del diagnóstico y el análisis estratégico a través de la matriz DAF0 o de impacto, facilitó la primera versión de misión, teniendo en cuenta las fortalezas y las oportunidades relevantes, así como la valoración de las principales líneas estratégicas existentes en la misión de los tres CES que se integran, y por otra parte con la utilización de filtros se ajustó, enriqueció, y enunciar finalmente la misión y los valores compartidos de la universidad en el marco de su encargo social:

Los principales ejes estratégicos contenidos en la nueva misión de la universidad integrada expresan la complejidad en el ámbito de actuación que ha decidido, y la necesaria interrelación con su capacidad distintiva y competitividad que debe y tiene que desarrollar: dirección científica; formación y superación; exigencia de la economía y los servicios; gestión con calidad; prosperidad y sostenibilidad.

La formulación de los valores compartidos fue el resultado de varias secciones de trabajo con las diferentes comisiones conformadas por expertos, especialistas y miembros del consejo de dirección de los tres CES que se integran, considerando el comportamiento que la organización debe desarrollar como deseado en cada eje estratégico contenidos en la misión

Los resultados de la Matriz DAFO en su primera versión denominada matriz de impacto sirvieron para formular el problema estratégico y la solución estratégica de la universidad integrada.

El proceso de planeación estratégica de la universidad integrada forma parte de la implementación de los lineamientos de la política económica y social del partido y la revolución aprobado en el VI congreso del PCC, resultado de particular importancia en el proceso de integración de los organismos formadores de la educación superior en la provincia de Guantánamo.

\section{Conclusiones}

La aplicación de la metodología propuesta con un enfoque prospectivo estratégico para la gestión universitaria vinculado al proceso de planificación estratégica de la universidad integrada, posibilitó realizar la una caracterización de cada uno de los centros que se integran determinando sus principales fortalezas y debilidades. Se consideraron los elementos siguientes: carreras y tipos de cursos en correspondencia con la demanda territorial, organización e 
integración de las actividades sustantivas, estructura y organigrama, instalaciones a utilizar en el territorio, principales relaciones con los CAM, CAP y los OACE.

El diagnóstico estratégico se enfocó en el levantamiento del estado actual de las estrategias de las organizaciones objeto de estudio, la misma facilitó evaluar el comportamiento y alcance de los resultados que debían estar produciendo las estrategias definidas, la evaluación se resume en un listado de fortalezas y debilidades que de orden estructural, de procesos fueron analizadas y que sirvieron de base para evaluar las potencialidades de cambio y en especial de integración presentan los tres Centros de Educación Superior (CES).

\title{
Bibliografía / References
}

1. Buck Consultants. Competency-Based Performance Management. Washington, D.C., 1998. URL: http://www.cinterfor.org.uy.

2. Chiavenato I. Administración de Recursos Humanos. Editorial Mc Graw-Hill. México, 1993. $568 \mathrm{p}$.

3. CINTERFOR/ OIT (2001). Competencia laboral y su impacto en el modelo de gestión. URL: http://www.cinterfor.org.uy.

4. Cuesta Santos A. Tecnología de Gestión de Recursos Humanos. Editorial Academia. La Habana, Cuba, 2010. 57 p.

5. Escuela Superior de Cuadros y el Gobierno. Materiales docentes del Diplomado. Compendio de lecturas de temas y Problemas de la Gestión de Administración Pública. Diplomado en Administración Pública VIII Edición. Habana, Cuba, 2014.

6. Harper y Lynch. Manuales de Recursos Humanos. Editorial Gaceta de los Negocios. Madrid, España, 1991. 234 p.

7. Michel Godet. Prospectiva Estratégica: problemas y métodos en colaboración con Philippe Durance y la participación de Prospektiker. Parque empresarial de Zuatzu- Edificio Urumea-20018 Donostia-San Sebastián. París, 2007. URL: http://www.prospektiker.es.

8. Nogueira Rivera Dianelis; Medina León, Alberto; Nogueira Rivera, Carlos. Fundamentos para el Control de la Gestión Empresarial. Editorial Pueblo y educación, 2004.

9. Puchol L. Dirección y Gestión de Recursos Humanos. 3ra Ed. Editorial Díaz de Santos. Madrid, España, 1997. 446 p.

10. VI Congreso del PCC. Lineamientos de la Política Económica y Social del Partido y la Revolución. La Habana, 2011. URL: http://www.cuba.cu/politica/webpcc/lineamientos.

\section{REFERENCE TO ARTICLE}

Delis Sevila Rodríguez, Alberto Turro Breff \& Jorge Olivares Boada (2018) Methodology for University Management with Prospective Approach in the Integration of Higher Education in Guantánamo, Contemporary Problems of Social Work. Vol. 4. No. 4 (16). P. 59-69. D0I: 10.17922/2412-5466-2018-4-4-59-69 (International bibliographic description).

\section{CONTACT INFORMATION:}

Delis Sevila Rodríguez

Ing., Profesor Asistente

Universidad de Guantánamo, Guantánamo, Cuba

E-mail: delissr@cug.co.cu

\author{
Alberto Turro Breff \\ Dr.C., Profesor Titular \\ Universidad de Guantánamo, Guantánamo, Cuba \\ E-mail: aturrob@cug.co.cu \\ Jorge Olivares Boada \\ Ms.C., Profesor Auxiliar \\ Universidad de Guantánamo, Guantánamo, Cuba \\ E-mail:jorgeab@cug.co.cu
}




\section{Delis Sevila Rodríguez,}

Ing. Profesor Asistente, Universidad de Guantánamo, Cuba.

E-mail: delissr@cug.co.cu

\section{José Antonio Rodríguez Oruña,}

Dr.C. Profesor Titular, Universidad de Guantánamo, Cuba.

E-mail:jaro@cug.co.cu

\section{Alberto Turro Breff,}

Dr.C. Profesor Titular, Universidad de Guantánamo, Cuba.

E-mail: aturrob@cug.co.cu

\section{METODOLOGÍA PARA LA GESTIÓN POR COMPETENCIAS HACIA EL DESARROLLO LOCAL EN LOS CENTROS UNIVERSITARIOS MUNICIPALES DE GUANTÁNAMO}

\section{Methodology for the Management By Competences Towards the Local Development in the Municipal University Centers of Guantánamo}
Receiving date:
Preprint date:
Taking to print date:
18.09.2018
19.11.2018
18.12.2018

Resumen: la investigación aplicada y realizada en Centros Universitarios Municipales de Guantánamo, siguiendo la gestión por competencias, para un desempeño superior e incremento de la gestión, proporcionó la integración de los procesos sustantivos: pregrado, investigación, desarrollo e innovación, posgrado y extensión universitaria en la que interactúan las categorías principales de profesor titular, auxiliar y asistente en correspondencia con los Planes de Desarrollo de los Municipios. En la fase de Diagnóstico, se utilizaron los modelos de Dirección por objetivos y centrado en valores y la Tecnología de Diagnóstico, Proyección y Control Estratégico de los Recursos Humanos.

Annotation: the applied and carried out research in Guantanamo Municipal University Centers, following the management by competences for a superior performance and increase of management, provided the integration of the substantive processes: undergraduate, research, development and innovation, postgraduate and university extension in which the main categories of tenured lecturer, auxiliary and assistant professor interact in correspondence with the Municipal Development Plans. In the Diagnostic phase, they were used the models of Direction by objectives centered in values and the Technology of Diagnosis, Projection and Strategic Control of the Human Resources.

Palabras clave: Centros Universitarios Municipales, gestión por competencias, procesos sustantivos, desarrollo local.

Key words: Municipal University Centers, management by competences, substantive processes, local development.

JEL classification: I200, I290.

\section{Introducción}

Los grandes cambios que se operan en el mundo contemporáneo unido al desarrollo de las ciencias han impactado con fuerza en la esfera laboral, provocando mejoras en los enfoques 
teóricos y en los métodos, surgiendo nuevos conceptos que dan respuesta a estas situaciones; es así que el término competencias invade el campo de la Gestión Integrada del Capital Humano (GICH), y consecuentemente las disciplinas científicas que abordan este objeto.

Cada factor productivo o de servicios debe trabajar de manera eficaz en el logro de los objetivos que estos cambios conllevan; y es aquí donde se llega a realizar el tratamiento del recurso humano como capital humano, es a este factor a quien debe considerarse de real importancia para aumentar sus capacidades y elevar sus aptitudes, de manera que se encuentre capaz de valerse por sí mismo y entregarle lo mejor de sí a su trabajo, sintiéndose conforme con lo que realiza y cómo es reconocido.

La gestión que comienza a realizarse ahora ya no está basada en elementos como la tecnología y la información; sino que "la clave de una gestión acertada está en las personas que en ella participan".

La Gestión por Competencias nace en el campo de la Psicología Organizacional, inmersa en teorías motivacionales buscando explicar el Desempeño Laboral exitoso; ahora hay que asumirla en la necesaria interdisciplinariedad de la Gestión de Recursos Humanos (GRH) y no podrá eludirse la complejidad de su objeto: las competencias de las personas en su interacción con los puestos de trabajo, el ambiente laboral y la cultura organizacional, donde la psicología humana y su epistemología ocupan un importante lugar.

El proceso de formación integral universitario constituye el objetivo primordial de la Educación Superior donde inciden de manera determinante la gestión de los procesos sustantivos que se desarrollan tales como: Pregrado, I+D+I, Postgrado y Extensión Universitaria.

La formación del estudiante universitario adquiere mayor connotación en las importantes transformaciones en las que se encuentra inmersa la universidad cubana. Proceso que incluye formación de conocimientos, habilidades y valores con capacidades para transformar el entorno, buscando soluciones a los problemas profesionales a que se enfrentan. Las universidades cubanas están orientadas hacia un proceso de perfeccionamiento que les permita ganar en eficiencia y competitividad, lo que las obliga a realizar una adecuada gestión como vía de garantizar el desarrollo de los procesos universitarios y su respuesta en lo económico-social, de ahí a su pertinencia y vinculación al Desarrollo Local; donde tratar la concertación estratégica de actores e intereses: Individuales (Profesor de excelencia y Graduado competente) - Institucionales (Universidad acreditada y pertinente al desarrollo local) - Territoriales (Gobierno territorial con liderazgo y el desarrollo local próspero y sustentable) es sumamente apremiante.

El desempeño de los procesos en los Centros Universitarios Municipales (CUM) de la provincia de Guantánamo no es suficiente ya que no se gestionan de forma integrada, ni con enfoque de sistema, lo que demuestra la falta de correspondencia con el resultado de los impactos alcanzados en el desarrollo local, influenciados por las limitaciones existentes en la concepción e implementación práctica del enfoque de Gestión por Competencias como una nueva alternativa para incrementar el rendimiento laboral, que responda a las exigencias de una integración armónica y sinérgica de los procesos sustantivos de la Educación Superior pertinente a las demandas de los Planes Integrales de Desarrollo Territorial; constituyendo esto la Situación Problemática de la presente investigación.

Desarrollar una "Metodología para la gestión por competencias hacia el desarrollo local en los Centros Universitarios Municipales de Guantánamo constituye el objetivo general del presente artículo científico.

\section{Desarrollo}

Las empresas están abocadas a incorporar nuevas estrategias para ser competitivas y nuestros trabajadores a tener los conocimientos, habilidades y destrezas que les permitan mantenerse en el mercado de trabajo y a desenvolverse en forma competente en los actuales procesos productivos y de servicios. 
Estos procesos, cada vez más exigentes, se caracterizan por la búsqueda de la creatividad, son gestionados con inteligencia por redes de trabajo que se constituyen en el interior de las diferentes organizaciones, se conforman de funciones polivalentes y apuntan a una producción diversificada.

Toda organización ha de gestionar su desempeño como vía para garantizar la generación de resultados en cumplimiento de su misión (Drucker, 2001; Hernández y otros., 2006) y en respuesta al objeto social que le corresponde (Lage, 2000). Las empresas u organizaciones en general no existen como un fin en sí mismas, sino que constituyen una vía eficiente y eficaz de satisfacción de las necesidades presentes y futuras de la sociedad, a través de la generación de bienes y servicios que resultan del desempeño de las mismas.

La competencia laboral es el elemento operativo que vincula la capacidad individual y colectiva para generar valor con los procesos de trabajo, por lo que constituye una nueva alternativa para mejorar el desempeño de los trabajadores y de la organización. Esta es sin dudas la finalidad de la Gestión por Competencias.

El empleo del término surge como una necesidad objetiva, de acercar el estudio, análisis y control de la actividad laboral a los procesos reales, por lo que su principal característica consiste en partir de los resultados, los objetivos y las funciones de la actividad a desarrollar.

Aún cuando en la literatura de gestión de recursos humanos se atribuye a David McClelland el surgimiento del término competencia, este tiene sus orígenes en la literatura de dirección estratégica, específicamente en Selznick, P. (1957) quien usó competencia distintiva para describir "aquellas cosas que una organización hace particularmente bien relativo a sus competidores" (Grant, 2002: 145). Así, el enfoque basado en competencias refleja el enfoque basado en los recursos (von Krogh y Roos, 1995) propuesto por (Wernerfelt, 1984) y popularizado por (Barney, 1986a, 1991a, 2001a; Barney y otros., 2001), desde el cual se observa a las organizaciones como un conjunto de recursos y capacidades.

Sin embargo, el enfoque de competencias y su desarrollo surge en los países industrializados y algunos en vías de desarrollo, principalmente a raíz de las transformaciones técnico-productivas ocurridas en la década de los ochenta (Mertens, 1996; Zarifian, 1999). Por otra parte (J. López y Leal, 2002), agrega que su surgimiento estuvo debido a la evidente incapacidad de los sistemas de formación profesionales tradicionales de responder a las necesidades de cualificación a los trabajadores para aumentar su desempeño y mantener cotas altas de competitividad.

Es por ello que el concepto de Competencias Laborales, emergió en los años ochenta con cierta fuerza en algunos países industrializados, sobre todo en aquellos que venían arrastrando mayores problemas para relacionar el sistema educativo con el productivo, como una respuesta ante la necesidad de impulsar la formación de la mano de obra. El problema que estos países visualizaron no era solamente de tipo cuantitativo; era también y sobre todo cualitativo: una situación donde los sistemas prevalecientes de educación-formación ya no correspondían a los nuevos signos de los tiempos. La respuesta era la Competencia Laboral desde un enfoque integral de formación, que desde su diseño conecta el mundo del trabajo y la sociedad en general con el mundo de la educación.

Según varios autores la gestión por Competencias surge con el sesgo del paradigma positivista y con la impronta del pragmatismo, tomando auge en la práctica empresarial avanzada y de éxito a partir de la década de 1990 (Levy-Leboyer (1997); Del Pino Martínez, Agustín (1997); Ducci, María Angélica (1997); Buck Consultants (1998); Herranz y de la Vega (1999)).

A inicio del siglo XXI, varios autores destacan la gestión estratégica de recursos humanos con enfoque de competencias laborales tanto a nivel nacional como internacional, entre ellos; en Cuba( Morales 2006), Oficina Nacional de Normalización (2007); Soltura; Cuesta (2008), Nogueira (2009); a nivel internacional Norton (2001); Prada (2002); Kaplan (2003); Reynoso (2004); Marín (2005).

A partir de ésta evolución se tienen varios conceptos de competencias laborales dada por diferentes autores y de acuerdo a la legislación vigente: 
En los años ochenta la Organización Internacional del Trabajo (OIT) ha definido el concepto de competencia como "capacidad efectiva para llevar a cabo exitosamente una actividad laboral plenamente identificada e idoneidad para realizar una tarea o desempeñar un puesto de trabajo eficazmente por poseer las calificaciones requeridas para ello. En este caso, los conceptos: competencia y calificación, se asocian fuertemente dado que la calificación se considera una capacidad adquirida para realizar un trabajo o desempeñar un puesto de trabajo.

La Resolución No. 21/ 99 del Ministerio del Trabajo y Seguridad Social (MTSS) define competencia laboral al "conjunto de conocimientos teóricos, habilidades, destrezas y aptitudes que son aplicados por el trabajador en el desempeño de su ocupación o cargo, en correspondencia con el principio de idoneidad demostrada y los requerimientos técnicos, productivos y de servicios, así como los de calidad, que se le exigen para el adecuado desenvolvimiento de sus funciones. Esta definición se enmarca fundamentalmente en aspectos cognitivos y está dirigida al desarrollo del proceso de formación en la organización".

González Maura, (2004) afirma que "competencia es la compleja integración de atributos que imprimen énfasis a la capacidad humana para innovar, para enfrentar el cambio y gestionarlo anticipándose y preparándose para él. Es más que la suma de todos esos atributos es un sistema que resulta de la combinación, interacción y puesta en práctica de dichos atributos en una situación laboral real".

La Norma Internacional NC-ISO 9000 del 2005 en Sistemas de Gestión de la Calidad, Fundamentos y Vocabulario resume "Competencia" como: "Aptitud demostrada para aplicar conocimientos y habilidades".

La Norma Cubana de Gestión Integrada de Capital Humano (2007) “define como el conjunto sinérgico de conocimientos, habilidades, experiencias, sentimientos, actitudes, motivaciones, características personales y valores, basado en la idoneidad demostrada, asociado a un desempeño superior del trabajador y de la organización, en correspondencias con las exigencias técnicas, productivas y de servicios. Es requerimiento esencial que esas competencias sean observables, medibles y que contribuyan al logro de los objetivos de la organización".

La gestión del desempeño por Competencias Laborales en los Centros Universitarios Municipales integrada a los Procesos Sustantivos y al desarrollo local, representa una buena alternativa para dar respuesta a la situación problemática de la presente investigación, para materializar la formación de los diferentes actores en las dimensiones económicas, agroindustrial, forestal, organización empresarial, ciencia, tecnología, innovación, cultura y medio ambiente entre otras con pertinencia en el Desarrollo Local ( Rodríguez J.A, 2014).

El Ministro de Educación Superior Dr. C Rodolfo Alarcón (2013): afirma que la pertinencia integral es un concepto que se caracteriza por las relaciones que se establecen entre la universidad y su entorno y se logra con efectividad si sus actores participan en la vida social, económica y cultural de la sociedad. La pertinencia integral de la universidad responde a los intereses y a las necesidades de su tiempo, de su sociedad, no solo para hacer lo que se solicita, sino para ser también agente propiciador de lo que realmente se necesita; ello significa, no solo pertinencia en el sentido de reproducción y legitimación de la vida económica, social y cultural, sino también en el sentido crítico, renovador, transformador (pp.1 y 2).

Los autores de éste artículo son del criterio que es necesario producir las trasformaciones institucionales y administrativas en correspondencia con las potencialidades endógenas y las condiciones objetivas, interrelacionando los Procesos Sustantivos de la Educación Superior a la Gestión Integrada del Capital Humano con la Competencia Individual y Colectiva, para generar valor e incrementar los impactos en el desarrollo local y el rendimiento laboral en los Centros Universitarios Municipales (CUM) de la Universidad de Guantánamo.

La Metodología que se propone abarca Procedimiento General e incluye los Procedimientos Específicos, que sustentan su implementación práctica que garantiza la integración de las Competencias Distintivas o Claves de los Centros Universitarios Municipales (CUM) , la 
de los Procesos Sustantivos de la Educación Superior y la de los cargos que la conforman; específicamente en las categorías docentes principales: Profesor Titular, Auxiliar y Asistente; de manera que marquen una diferencia ventajosa en el desarrollo social e incremente la eficiencia y eficacia; así como la integración a la implantación e implementación de un Sistema de Gestión de la Calidad en función de los Planes de Desarrollo Integrales de Municipios y Provincia acorde a la legislación establecida por el Ministerio de Educación Superior y los organismos correspondientes.

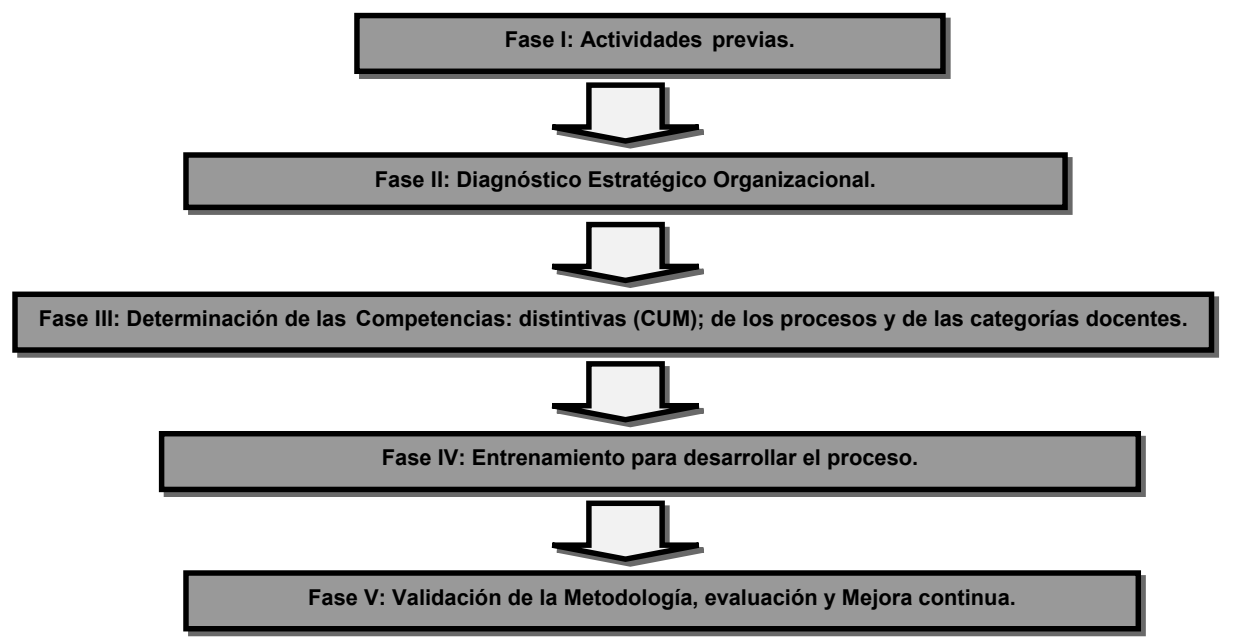

Figure 1. Procedimiento General para la Evaluación del desempeño por competencias integrando los procesos sustantivos al desarrollo local

El Procedimiento General (fig. 1) abarca cinco fases, en la primera se utiliza la Tecnología para el diagnóstico, proyección y control de gestión estratégica de los recursos humanos (Cuesta, 2010) que tiene como objetivo diagnosticar la situación actual y la proyección deseada del Sistema de Gestión de los Recursos Humanos; esta incluye los factores de base que la componen las fuerzas decisivas del entorno y del interior de los Centros Universitarios Municipales, las características de las personas que trabajan: edad, sexo ,categorías docentes, además de las motivaciones, capacidades o aptitudes, valores, potencial y deseo de progreso personal de los empleados y se obtienen a partir de técnicas como: observación, entrevistas y encuestas, empleando el método diagrama de Ishikawa o causa - efecto (espina de pescado), aplicándolo a un grupo representativo de la alta dirección, los empleados y el sindicato; además se contemplan los Planes de Desarrollo de cada Municipio, así como la demanda actual de fuerza calificada para dar respuesta a su cumplimiento.

La segunda etapa corresponde al desarrollo del Diagnóstico Organizacional, incluye los resultados obtenidos en la primera etapa, más la aplicación de un instrumento que contiene 80 preguntas que responden a 4 variables: Liderazgo, Motivación, Participación, Reciprocidad con sus correspondientes indicadores y dimensiones; estas variables se operacionalizaron, dándole un valor para su posterior ponderación, utilizando la escala de likert, métodos estadísticos como: análisis porcentuales para el procesamiento de los datos recopilados a través de las encuestas y permitió contabilizar los resultados obtenidos de los cuestionarios aplicados, la propia utilización de diversas herramientas ha sido un criterio de validez de la metodología empleada y se analizaron integralmente los resultados cuantitativos y cualitativos obtenidos; como procesador estadístico se utilizó el Statistical Package for the Social Sciences (SPSS), versión 15.0 para Microsoft Windows. 
Tomando en consideración la influencia que el clima organizacional tiene en los destinos de la organización, se hace imprescindible invertir capital en hacer estudios sobre el mismo para determinar los puntos débiles y de inmediato concebir acciones correctivas y modificadoras, que garanticen que no se altere en una magnitud tal que vaya a conspirar contra el logro de las estrategias y objetivos, deteriorando la motivación y satisfacción laboral del colectivo.

Desde nuestra perspectiva, el propósito es determinar si los elementos considerados para diagnosticar el clima organizacional se tratan de comprender conscientemente para que desde una evaluación se conozcan las consecuencias que producen en materia de desempeño. Si se cuenta con buenos datos y procesos para realizar esa evaluación, se puede tener un nivel de confianza en la percepción que tienen los miembros de la organización acerca del mismo y a su vez en la búsqueda de mejora en el desempeño organizacional.

Autores como (Rodríguez, D. (1999), Guillén, (2000)), sugieren medir el Clima Organizacional por medio de las siguientes dimensiones:

1. Actitudes hacia la compañía y la gerencia de la empresa.

2. Actitudes hacia las oportunidades de ascenso.

3. Actitudes hacia el contenido del puesto.

4. Actitudes hacia la supervisión.

5. Actitudes hacia las recompensas financieras.

6. Actitudes hacia las condiciones de trabajo.

7. Actitudes hacia los compañeros de trabajo.

La gestión de recursos humanos por su parte, se demuestra en el carácter sistémico de interacción con el entorno, donde se destacan tres factores fundamentales: el mercado laboral formado por todas las empresas que a la vez son competidoras y ofrecen los productos/servicios; el gobierno con el cumplimiento de la reglamentación establecida, y la sociedad representada por los clientes externos (reales y potenciales) y los clientes internos (potenciales) que forman el mercado de fuerza de trabajo.

El conocimiento es el segundo elemento esencial de la filosofía de la gestión, del aprendizaje organizacional y gestión por competencias, así como la cultura organizacional que incide en la concepción de la actual gestión de recursos humanos. También se consideran como factores internos, la tecnología, los procesos y los recursos, que demandarán el desarrollo y/o adquisición de determinadas competencias.

El carácter sistémico como tercer aspecto se demuestra dentro del propio Sistema de Gestión Integrada del Capital Humano diseñado y está formado por varios procesos interrelacionados. El insumo fundamental que orienta la administración del Recurso Humano y la inversión de los activos de competencias en procesos claves para la organización y el control de los mismos, es el mecanismo inherente a su mejora continua.

En cuanto a la gestión se produce un intercambio de información que le permite a cada proceso, obtener las competencias como insumo. La esencia es enfatizar en el hecho de la gestión de los Recursos Humanos, a partir del desempeño por competencias, alineadas a los objetivos estratégicos, permiten la evaluación sistemática de los resultados obtenidos y la valoración del impacto de los niveles de competencias, en términos de los resultados de los indicadores referidos a los clientes, tanto externos como internos.

En la tercera etapa se determinaron las Competencias claves de la Organización en éste caso de los Centros Universitarios Municipales (CUM); de los procesos sustantivos (pregrado, I+D+I, postgrado, y extensión universitaria) y de las categorías principales Profesor Titular, Auxiliar y Asistente, según lo que establecen las NC 3000-3002:2007 y se sometió a validación por el grupo de expertos, a través del método DELFHI.

La cuarta etapa consistió en la preparación del personal para aplicar el proceso. 
En la quinta etapa se validó la Metodología en los Centros Universitarios Municipales San Antonio del Sur, Baracoa y el Salvador, determinándose el efecto económico, político y social; así como las estrategias a seguir para la mejora continua.

\section{Conclusiones}

- Se aporta una Metodología novedosa que aborda holísticamente y en sistema el fenómeno del Desempeño por Competencias Laborales en los Centros Universitarios Municipales (CUM), integrando coherentemente los Procesos Sustantivos de la Educación Superior: Pregrado, I+D+I, Postgrado y Extensión Universitaria y el Desarrollo Local con sus potencialidades endógenas, direccionadas a satisfacer las demandas del Plan de desarrollo territorial.

- Con la aplicación de la metodología se demostró que la gestión integrada constituye una expresión de cambio en los Centros Universitarios Municipales de la Universidad de Guantánamo (CUM) incrementando los conocimientos en los diferentes procesos sustantivos y la dinámica de la gestión de la ciencia, la tecnología, la innovación y el medio ambiente, con una nueva proyección estratégica para su organización.

- Se realiza un análisis prospectivo cuyo objetivo es proponer orientaciones estratégicas y acciones basadas en las competencias de la organización en función de los escenarios de evolución de su entorno.

- La creación de las capacidades en la metodología y su aplicación en cada instancia constituyen aspectos novedosos para el proceso de integración y para el ordenamiento de la gestión del conocimiento que demanda el desempeño en la Educación Superior.

Recomendaciones: Continuar investigaciones referentes al tema objeto de estudio para dar continuidad al desarrollo sostenible de los territorios.

\section{Bibliografía / References}

1. Alarcón R. La Educación Superior en el Sistema Nacional de Ciencia, Tecnología e Innovación, discurso, La Habana, 2015.

2. Cuesta A. Tecnología de Gestión de Recursos Humanos. Cuarta Edición, partes 1 y 2. La Habana: Félix Varela, 2010.

3. Gárciga R. Formulación estratégica: Un enfoque para directivos. La Habana: Félix Varela, 2001.

4. Kaplan R.S., Norton D.P. Mastering the Management System. Harvard, 2008.

5. Business Review. 1986. No. 1. P. 62-77.

6. Lage Dávila A. El debate sobre ciencia y universidad. En Blanco Godínez F. (Comp.): La ciencia universitaria en el contexto de la actualización del modelo económico cubano. Editorial Universitaria - Félix Varela . La Habana, 2013.

7. Levy-Leboyer Claude. Gestión de las competencias / Ed. Gestión 2000. Barcelona, España, 1997.

8. Mertens Leonard. La gestión por competencia laboral en la empresa y la formación profesional. CINTERFOR / OIT. Montevideo, Uruguay, 1996. URL: http://www.cinterfor.org.uy/.

9. Morales Cartaya Alfredo. Contribución para un modelo cubano de gestión integrada de los recursos humanos. Tesis en opción al grado científico de doctor en ciencias técnicas. ISPJAE. Ciudad de La Habana, Cuba, 2006. 99 p.

10. MTSS. Resolución No. 21 de 1999. Reglamento para la capacitación profesional de los trabajadores en las organizaciones en Perfeccionamiento Empresarial. Ministerio de Trabajo y Seguridad Social (MTSS). La Habana, Cuba. 1999.

11. Núñez J. Universidad, conocimiento, innovación y desarrollo Local. La Habana: Félix Varela. La Habana, 2014.

12. Rodríguez J.A. Arquitectura Organizacional para el acompañamiento universitario a los Planes Integrales de Desarrollo Municipales. Municipio San A. del Sur. Taller Nacional de GUCIT. UCI, 2014.

13. Socorro Castro A.R., Castro Perdomo N.A., Tartabull Contreras Y., Padilla Haramboure M.M. Línea base para le gestión municipal de la ciencia, la tecnología y la innovación en la provincia Cienfuegos. 2014. 


\title{
REFERENCE TO ARTICLE
}

Delis Sevila Rodríguez, José Antonio Rodríguez Oruña \& Alberto Turro Breff (2018) Methodology for the Management By Competences Towards the Local Development in the Municipal University Centers of Guantánamo, Contemporary Problems of Social Work. Vol. 4. No. 4 (16). P. 70-77. DOI: 10.17922/2412-5466-2018-4-4-70-77 (International bibliographic description).

\section{CONTACT INFORMATION:}

\section{Delis Sevila Rodríguez}

Ing., Profesor Asistente

Universidad de Guantánamo, Guantánamo, Cuba

E-mail:delissr@cug.co.cu

\author{
José Antonio Rodríguez Oruña \\ Dr.C., Profesor Titular \\ Universidad de Guantánamo, Guantánamo, Cuba \\ E-mail:jaro@cug.co.cu
}

\author{
Alberto Turro Breff \\ Dr.C., Profesor Titular \\ Universidad de Guantánamo, Guantánamo, Cuba \\ E-mail: aturrob@cug.co.cu
}




\title{
Gener Chang Jorge,
}

Lic., Prof. Auxiliar, Universidad de Guantánamo, Cuba.

E-mail:santi@cug.co.cu

\section{Yaritza Martínez Adams,}

M. Sc., Prof. Auxiliar, Universidad de Guantánamo, Cuba.

E-mail:santi@cug.co.cu

\section{VALOR DIDÁCTICO DE LAS PRÁCTICAS DE CAMPO EN LA ENSEÑANZA INTEGRADORA DE LAS CIENCIAS NATURALES}

\author{
Didactic Value of the Farm Practices in the Integrative Teaching \\ of the Natural Sciences
}

\author{
Receiving date: \\ Preprint date: \\ 12.09.2018 \\ 19.11.2018 \\ Taking to print date: \\ 18.12.2018
}

Resumen: La ciencia, como un polifacético fenómeno social, ha demostrado de manara convincente que los diversos fenómenos, hechos y fenómenos que se manifiestan en la naturaleza tienen una propiedad que los une: la materialidad. La unidad del mundo significa que todos los objetos, fenómenos y procesos están ligados entre sí de manera que constituyen un todo único material; así, por ejemplo, la Química ha demostrado la capacidad de transformación recíproca de los elementos químicos; la Biología ha evidenciado que los organismos, independientemente del nivel de complejidad que presentan, están constituidos por los mismos elementos químicos que los minerales, aunque en combinaciones químicas y biológicas más complejas; la Geografía, además de posibilitar la ubicación espacial de los objetos, hechos, pereceos y fenómenos, analiza la integración de los componentes naturales dentro del marco socioeconómico donde se desarrolla el hombre.

Annotation: the science, like a versatile social phenomenon, has demonstrated of gush convincing that the various phenomena, facts and phenomena that are shown at nature have a property that joins them: Materiality. The worldly unit means that all objects, phenomena and processes are related among themselves so that they constitute the only material whole; That way, for example, the Chemist has demonstrated the capability of reciprocal transformation of the chemical elements; The Biology has evidenced than organisms, independently of the level of complexity that they present, they are composed of the same chemical elements than minerals, although in chemical and biological combinations more complex; The Geography, in addition to make possible the space position of the objects, facts, pereceos and phenomena, examines the integration of the natural components within the socioeconomic frame where the man develops.

Palabras clave: Práctica de Campo, ciencias naturales, integración, proceso de enseñanza - aprendizaje, trabajo de campo.

Key words: Practice of Campo, natural sciences, integration, process of teaching - learning, work of field.

JEL classification: I200, I290.

\section{Introducción}

Las Ciencias Naturales tienen entre sus propósitos contribuir a fomentar en los estudiantes el amor, cuidado y conservación del medio ambiente, la formación de una concepción científica del mundo, una concepción didáctica que devele la utilidad social de las mismas, el desarrollo 
de un modo de actuación estética y el pleno desarrollo de las capacidades intelectuales, físicas y espirituales del individuo.

Para lograr un enfoque sociocultural - profesional en la enseñanza de las ciencias naturales, es imprescindible que los profesores de estas ciencias alcancen una adecuada preparación, de manera que les permita una correcta interpretación de las generalizaciones que, dentro de su sistema de conocimientos, contienen las ciencias naturales.

$\mathrm{Si}$, al abordar cualquier contenido físico, químico, biológico o geográfico, no lo relacionamos entre sí desde una óptica integracionista y desde un enfoque sociocultural que pondere las implicaciones sociales de los mismos, los estudiantes solo se apropiarán de conocimientos que enriquecen su nivel cultural, pero no les sirven de base para una visión y cultura científica materialista del mundo.

Lo anterior puede lograrse mediante la planificación de diferentes formas de organización del proceso de enseñanza - aprendizaje; entre ellas las prácticas de campo, en la cual los estudiantes interactúan directamente con el medio ambiente, convirtiéndose en observadores activos.

La enseñanza de las Ciencias Naturales no se concibe, si los conocimientos tratados teóricamente en el aula no tienen una continuidad en las condiciones naturales, en las que pueden ser comprobados y aplicados en la práctica, contribuyendo al desarrollo del enfoque sociocultural - profesional de las Ciencias Naturales, que permite mayor accesibilidad a los componentes del medio ambiente, favorece la transferencia y aplicación del sistema de conocimientos adquiridos teóricamente, permitiendo a los estudiantes resolver problemas que se presentan en el contexto aúlico.

El nivel de actualidad de la problemática no significa que sea nueva, en la raíces de la educación cubana, encontramos latente esta idea en nuestros más insignes pedagogos. Así, José Martí Pérez insistió en la conveniencia del conocimiento de la Naturaleza por lo hombres, al expresar: "Divorciar al hombre de la tierra es un atentado monstruoso, y eso es meramente escolástico: ese divorcio. A las aves; alas; a los peces, aletas; a los hombres que viven en la naturaleza, el conocimiento de la Naturaleza: esas son sus alas"1.

Las Prácticas de Campo contribuyen a desarrollar en los estudiantes habilidades que permiten ampliar, profundizar e integrar el sistema de conocimientos y habilidades, a relacionarlos con los objetos, hechos y fenómenos en su medio ambiente y a la expresión correcta de sus ideas, tanto de forma oral como escrita.

A decir del Dr. C Salvador Massip (citado por León Méndez, 1995), la Práctica de Campo ocupa un lugar relevante en la enseñanza de las Ciencias Naturales, ya que constituye una vía lógica para consolidar los conocimientos teóricos y desarrollar habilidades en los estudiantes que les permita autoaprender en contacto con la Naturaleza.

Las prácticas de campo familiarizan a los estudiantes con los objetos, hechos y fenómenos de la naturaleza y la sociedad y de la interacción entre ambas, al estar en estrecha relación con el medio ambiente, contribuyendo a la educación estética de los estudiantes, la orientación sociocultural del contenido de enseñanza y los sentimientos de amor hacia el entorno natural.

\section{Desarrollo}

El término práctica de campo debe asumirse como un genérico, que posee una sinonimia científica en la que pueden apreciarse términos como excursión (geográfica, docente, a la Naturaleza y otros) y trabajo de campo, por referirnos a los más empleados. En este sentido, varios han sido los pedagogos han definido el término excursión (Mejías, 1976; Silvestre, 1978); Yakoliev, 1979; Barraqué Nicolau, Gracilela, 1991; Guerra Sanz, José M, 1994; Guzmán Callazo, Nilda, 2000 y otros).

Algunos la consideran como forma de trabajo docente, trabajo de campo, otros como forma de organización del proceso docente educativo, hay quienes la definen como una visita, paseo o

1 José Martí Pérez: Obras Completas Tomo 5, p. 110. 1975. 
caminatas con objetivo didáctico, y no faltan los que la definen como una actividad extradocente o como clases extraescolares existiendo divergencias en otros elementos. En lo adelante cuando se haga referencia al término excursión nos referimos a la práctica de campo; como la forma de organización del proceso de enseñanza - aprendizaje que se realiza en la Naturaleza, en un área que reúna los requisitos para lograr los objetivos propuestos.

La práctica de campo, como forma de organización, debe estar planificada en el currículum de las asignaturas del año, de manera que haga posible explotar al máximo sus posibilidades instructivas, educativas, socioculturales y profesionales.

A decir de Graciela Barraqué: “Esta forma de organización de la enseñanza posee un gran valor pedagógico, puesto que permite la vinculación de la escuela con la vida, de la teoría con la práctica y la asimilación de los conocimientos mediante la observación de los objetos y fenómenos en su propio ambiente, o sea, que convierte a la realidad en un medio de enseñanza" ${ }^{1}$.

Para que la enseñanza de las ciencias pueda provocar un aprendizaje integrado y desarrollador en la formación de profesores que estimule el pensamiento científico, el desarrollo del enfoque sociocultural - profesional, que le permita la formación de valores, el desarrollo de la creatividad y de una cultura general integral; el profesor debe contar con procedimientos didácticos que le orienten hacia modos de proceder consecuentes en cada forma de actividad docente, de manera que le permitan hacer conciencia a los estudiantes de cómo aprender mejor para interpretar y transformar su entorno.

Las prácticas de campo proporcionan el vínculo de los estudiantes con la vida, con la utilidad práctica de las asignaturas que recibe en el aula, con la naturaleza, con el trabajo, con la comunidad, en fin, con su entorno y es una actividad con muchas potencialidades para la formación de valores, para la adquisición del aprendizaje, siendo el alumno protagonista del mismo.

Son las prácticas de campo, bien concebidas, una vía que propicia el aprendizaje interdisciplinar e integrado de las ciencias, aspectos por los que tanto se aboga en el proceso de enseñanza aprendizaje, lo cual favorece además, el desarrollo del enfoque sociocultural - profesional a partir de los contenidos de las asignaturas del currículo.

Por tales razones y considerando la necesidad que existe en el sistema de educación en Cuba y en otros países de Ibero América de explotar esta forma de organización, nos planteamos como objetivo elaborar un material didáctico sobre las prácticas de campo, de manera de capacitar a los profesores en el uso de este tipo de forma de organización como una vía para establecer relaciones interdisciplinarias, integrar las ciencias naturales y desarrollar el enfoque sociocultural - profesional en la formación de profesores.

Muchos docentes opinamos que la excursión puede ser una clase, no una clase tradicional en el aula, sino fuera de ella, en el campo, en un museo, en una fábrica, etc. y por tanto todas las exigencias a una clase usual son válidas también para la excursión, pero explotando las posibilidades metodológicas y formativas que esta ofrece.

Así también y según los criterios de Graciela Barraqué (1991) y Nilda Guzmán Collazo (2000), las prácticas de campo pueden ser clasificadas como:

1. Prácticas de Campo de Orientación: orientan a los estudiantes los objetivos propuestos, entrenándolos en las técnicas y procedimientos a utilizar en otros tipos de prácticas de campo y se realiza generalmente en áreas cercanas al centre de estudio.

2. Prácticas de Campo de Introducción: para iniciar un nuevo contenido, facilita el aprendizaje en clases posteriores. Se organiza para motivar a los estudiantes hacia el estudio de objetos y fenómenos de la naturaleza.

3. Prácticas de Campo de Asimilación de nuevos contenidos y habilidades: permite el desarrollo cognoscitivo en los estudiantes. Propicia la formación de representaciones y conceptos sobre objetos, hechos y fenómenos. Utiliza métodos y procedimientos científicos.

${ }^{1}$ Colectivo de especialistas. Pedagogía. La educación extradocente y extraescolar. Editorial Pueblo y Educación. Ciudad de la Habana, 1981. 
4. Prácticas de Campo de Aplicación de los conocimientos: para corroborar en la práctica los conocimientos y habilidades adquiridas. Se organizan y planifican generalmente al finalizar una o varias unidades del programa de estudio. Tiene carácter de sistematización y generalización de los contenidos de las clases. Permite el control y evaluación del aprendizaje.

En las prácticas de campo se pueden realizar cálculos, mediciones o estimados, tomar datos numéricos de diferentes magnitudes o datos económicos y elaborar tablas, hacer distintos gráficos; también tomar muestras de minerales, fósiles, plantas, rocas, materias primas, productos, semillas, hojas, fotos y otros, realizar valoraciones sobre el impacto del hombre en el ecosistema y sus componentes, valorar la importancia social de las actividades que realizan, entre otras actividades, con las que se pueden trabajar en el lugar de la práctica de campo, en la casa o en la escuela y posteriormente montar una exposición.

Analicemos a continuación cómo consideramos que se debe concebir una práctica de campo. El proceso para concebir la práctica de campo lo hemos dividido en 6 etapas, con el ánimo de facilitarle al profesor los pasos a seguir en este empeño. A continuación se explican cada una de ellas y su interrelación la cual se puede apreciar en el anexo 1.

\section{Planificación:}

1. Análisis del programa de las asignaturas del año para determinar el sistema de conocimientos y posibles lugares a visitar teniendo en cuenta los objetivos del año y las asignaturas.

2. Valorar según la dosificación las fechas posibles y elaborar el plan de práctica de campo donde se planteará en cada caso: tema, objetivos, lugar, fecha, número de participantes, organización, recursos materiales, guía o manual de práctica de campo, itinerario con rutas a seguir, estaciones u objetos económicos a visitar, orientaciones para el trabajo independiente, materiales y evaluación.

3. Dar a conocer en el colectivo de disciplina Práctica de Campo, el plan de práctica para coordinar acciones docentes, formativas y organizativas, como la integración de otras ciencias, horario docente, entre otras.

4. De acuerdo a las características de la práctica de campo presentar la "planificación" de la misma al consejo de dirección de la facultad para precisar y concretar aspectos como transporte, recursos alimenticios, horario, coordinaciones en el polígono de práctica y otros.

\section{Preparación:}

1. Se realizará una visita al polígono seleccionado para la práctica de campo, con la intención de realizar las coordinaciones pertinentes, debiéndose precisar cuando sea necesario objetivos de la actividad, personas que atenderán a los estudiantes, acciones a realizar por la entidad y por los estudiantes de acuerdo a los objetivos. Se observará bien el lugar y las zonas aledañas, tomando las notas necesarias que faciliten posteriormente al profesor concebir la guía de actividades a desarrollar por los estudiantes, la determinación de los materiales necesarios y se deberá prever la ruta del recorrido a realizar.

2. Cuando sea a un lugar de producciones materiales o de alimentos el docente en la visita al lugar debe estudiar los talleres principales y auxiliares, laboratorios, corrales, almacenes de materia prima, de productos elaborados, de medicamentos, analizar los procesos físicos, químicos y biológicos, etc, de manera que pueda determinar la ruta a seguir y coordinar con la administración del centro los objetivos de la práctica de campo y aspectos de interés a destacar en la intervención de los especialistas (para lo cual se puede elaborar una guía la que facilitará el trabajo del especialista y garantiza al profesor que se aborden los aspectos de interés, además del cumplimiento del tiempo destinado a esta parte de la excursión), sin olvidar la orientación vocacional o profesional de los estudiantes.

3. Si es necesario de regreso a la centro reajustar el plan e informar los cambios a las personas implicadas.

4. Concebir la guía de actividades para la práctica de campo, que desarrollarán los estudiantes considerando los objetivos previstos y las características del polígono, la integración de las 
ciencias, los elementos del método investigativo que se puedan introducir, y la formación del enfoque sociocultural - profesional, desde las asignaturas. Se debe prever el tiempo aproximado para la ejecución de las actividades, orden del recorrido, e instrumentos o materiales necesarios. De manera que en el desarrollo de la práctica de campo, el profesor no tenga que estar dando orientaciones constantemente y se garantice el cumplimiento de las actividades.

5. Revisión adecuada y racional de los equipos, instrumentos, utensilios, reactivos y otros, que deben estar en correspondencia con las actividades planificadas.

6. Elaboración del reglamento que incluya las normas de disciplina general, de protección e higiene del trabajo, así como aquellas que garanticen la protección del medio ambiente.

7. Explicación a los participantes de los aspectos organizativos y metodológicos, teniendo en cuenta: lugar donde se realizará, objetivos de la práctica, características biogeográficas del lugar, zonas donde se desarrollaran las actividades previstas en el plan de práctica de campo, ropa apropiada para el desarrollo de la práctica y reglamento para el trabajo en el área seleccionada.

8. La guía se debe reproducir, e manera que se le entregue previamente a los estudiantes y se pueda utilizar por varios cursos, de no ser posible se aplicarán otras variantes como colocarla en el mural para que los estudiantes la copien, dictarla, etc.

9. Organización de los estudiantes en equipos y selección del jefe de cada uno.

10. Estudio de las patologías de los estudiantes mediante estudio de su historia clínica o por los métodos de encuesta, entrevista a los estudiantes para proyectar tanto la preparación física previa, como para limitar las acciones y operaciones físicas o mecánicas que pueden representar una carga física no aconsejable en el transcurso de la práctica de campo.

\section{Orientación:}

1. Informar a los estudiantes el plan de práctica de campo y motivarlos hacia la actividad.

2. Informar la guía de práctica de campo, donde aparecerán las actividades a realizar por los adolescentes, los materiales necesarios (como lupas, recipientes, bolsas de nylon, cuchillas, etc) y cómo presentar los resultados. A consideración del docente se puede hacer referencia al tiempo aproximado para cada actividad. De acuerdo a los objetivos de la excursión, a las características del lugar y diagnóstico de los estudiantes, el profesor podrá concebir en la guía actividades individuales, de pequeños grupos o ambas. Recomendamos que se prevean los problemas organizativos y de disciplina en caso de que se decida combinar actividades individuales y de grupos.

\section{Desarrollo}

1. El profesor u otro especialista dará una pequeña introducción y de inmediato se comenzará a ejecutar la guía de actividades a través de la ruta de recorrido.

2. Supervisar la actividad de los estudiantes, guiarla y controlarla, en un clima psicológico agradable, pero donde se garantice la disciplina y la actividad independiente, cooperativa, 0 ambas según se halla previsto.

3. Se observará el cumplimiento del tiempo de las actividades, prestando niveles de ayuda con la intervención de las personas mayores, solo en casos estrictamente necesarios.

4. El profesor y colaboradores si los tuviera, tomarán notas que consideren importantes tener en cuenta para análisis posteriores como, grado de iniciativas, interés, independencia, disciplina, creatividad, errores de procedimientos, etc.

5. Concluir al finalizar las actividades planificadas de forma muy breve, estimulando a los estudiantes que se hallan destacado, escuchando opiniones sobre qué fue lo que más gustó, qué gustó menos, lo más interesante, etc. Las conclusiones finales se pueden realizar en la escuela o en el lugar visitado según lo considere el profesor.

El éxito del desarrollo de la práctica de campo estará dado fundamentalmente por la calidad con que se realicen las etapas de preparación y orientación, sin dejar de significar la relación que se expresa en el gráfico de interrelación entre todas las etapas. 


\section{Presentación de los resultados:}

En la presentación de los resultados se les dará la posibilidad a los estudiantes de manifestar el desarrollo de su iniciativa y creatividad. El profesor en la etapa de orientación establecerá los aspectos que el estudiante reportará como resultado de su aprendizaje en las actividades relacionadas con la práctica de campo, precisando en los casos necesarios cómo y cuándo se realizará la presentación de los resultados lo cual estará en correspondencia con las características de la excursión y puede ser:

- de forma oral, a través de exposiciones, debates, talleres, respuestas a interrogantes, etc.;

- de forma escrita como informe, resumen, respuestas a preguntas, cuentos, poesías, dibujos, etc.;

- otras formas de presentarlos son en muestrarios, maquetas, modelos, y la combinación de algunas de ellas.

\section{Conclusiones}

El uso de este material por los profesores de ciencias naturales contribuirá a capacitar a los docentes para explotar todas las potencialidades de la práctica de campo como forma de organización, para establecer relaciones ínterdisciplinas, integrar las ciencias y desarrollar el enfoque sociocultural - profesional desde las mismas.

\section{Bibliografía / References}

1. Colectivo de Autores (2004) Apuntes para una didáctica de las Ciencias Naturales. Ciudad de Habana: Pueblo y Educación.

2. Barraque Nicolau, G. (1991) Metodología de la Enseñanza de la Geografía. La Habana: Pueblo y Educación.

3. Bernal, J.M. (1993) Las actividaes de laboratoio y de campo en la enseñanza de las Ciencias Naturales. Revista investigación y experiencias didadcticas. De especial, Madrid, España, 13-16.

4. Cutára López, R. (1998) Una propupoesta teorica matodológica para el estudio de la localidad en la enseñanza de la Geografía escolar. La Habana.

5. Gonzales, L.D. (2002) La excursión: Una vía para integrar las Ciencias Naturales y desarrollar una cultura general integral en los estudiantes. Memorias del Comgreso Ibero Americano de Didactica de las Ciencias Naturales.

6. Guerra Sanz, J.M. (1994) El laboratorio y el trabajo de campo en la enseñanza de la Biología. Departtamento de Biología Vegetal. Universidad de Cordova, España.

7. Guzmán Collaza, N. (2000) Un manual de práctica de Campo para la asignatura Botánica I. Ciudad de la Habana.

8. José, M.P. (1975) Obras Completas Tomo 8. La Habana: Ciencias Sociales.

\section{REFERENCE TO ARTICLE}

Gener Chang Jorge \& Yaritza Martínez Adams (2018) Didactic Value of the Farm Practices in the Integrative Teaching of the Natural Sciences, Contemporary Problems of Social Work. Vol. 4. No. 4 (16). P. 78-83. D0I: 10.17922/2412-5466-2018-4-4-78-83 (International bibliographic description).

\section{CONTACT INFORMATION:}

\section{Gener Chang Jorge}

Lic., Prof. Auxiliar

Universidad de Guantánamo, Guantánamo, Cuba

E-mail:santi@cug.co.cu

\section{Yaritza Martínez Adams}

M. Sc., Prof. Auxiliar

Universidad de Guantánamo, Guantánamo, Cuba

E-mail:santi@cug.co.cu 


\section{Maribel Santiesteban Pérez,}

Dr. C., Profesora Titular, Asesora del Rector, Universidad de

Guantánamo, Cuba.

E-mail:santi@cug.co.cu

\section{Roger David Desten Santiesteban,}

Profesor Instructor, Especialista en Informática, Empresa Nacional de desarrollo de Software (DESOFT), Universidad de Guantánamo, Cuba.

E-mail: roger@gtm.desoft.cu

\section{CAMBIOS ESTRUCTURALES EN LA FAMILIA ACTUAL. COMPENDIO REFLEXIVOS}

\section{Structural Changes in the Current Family. Reflexive Compendium}
Receiving date:
Preprint date:
Taking to print date:
14.09.2018
19.11.2018
18.12.2018

Resumen: Los cambios que se originan en el orden social, cultural y económico generan en las sociedades modificaciones estructurales en los niveles de comportamiento que tienen y manifiestan los miembros de la familia en sus sectores educativos, originando conductas diferentes a otras atapas del marco histórico referenciar.

De ahí la necesidad de reflexionar y buscar estrategias educativas desde las universidades en función de desarrollar patrones de comportamientos sobre la base del respeto a la convivencia intergeneracional, en tanto el propio desarrollo tecnológico y su uso proporcionan nuevos conflictos y miradas diferentes en las decisiones que se adoptan entre los adultos y los más jóvenes, entender a los más jóvenes es sinónimo de respeto y de escalar peldaños superiores en las formas de ver el progreso social.

Annotation: the changes that originate in the social, cultural and economic order generate in the societies structural modifications in the levels of behavior that the members of the family have and show in their educational sectors, originating different behaviors to other ataps of the historical reference frame.

Hence the need to reflect and seek educational strategies from universities in order to develop patterns of behavior on the basis of respect for intergenerational coexistence, while the technological development itself and its use provide new conflicts and different views in the decisions that are made. Adopt between adults and the youngest, understanding the youngest is synonymous with respect and climbing higher rungs in the ways of seeing social progress.

Palabras clave: intergeneracional, conflictos, estrategias, comportamientos.

Key words: intergenerational, conflicts, strategies, behaviors.

JEL classification: $A 140$.

\section{Introduction}

La familia es la institución social que recibe al ser humano desde su nacimiento y del cual surgen más tarde sus miembros más jóvenes constituyéndose en la fuente de sus relaciones más duraderas y su primer sustento económico. La familia tiene el deber de producir más recursos para lograr cambios en los más jóvenes, en ella aprenden valores, principios, normas y costumbres que le afectaran por toda la vida.

La familia es una de las instituciones de mayor influencia en la vida de las personas. En ella, la educación familiar se puede describir como una intervención de los padres mediante la cual 
el hijo puede aprender a prepararse para recorrer el viaje de su vida y adquirir las habilidades que le permitan valerse por sí mismo en un mundo como el actual complejo y cambiante.

Tenemos, que mientras los padres hacen un reconocimiento de la brevedad o cortedad del tiempo los más jóvenes deben prepararse para un futuro abierto donde el tiempo es ilimitado.

Si los adultos y los más jóvenes no son capaces de entenderse y de acondicionarse unos a otros puede entonces quedar atrapado en el conflicto.

\section{Desarrollo}

Los cambios en la familia durante los últimos cuarenta años han sido los más profundos y convulsivos de los últimos veinte siglos, apareciendo hoy un gran número de modelos que alteran de forma directa los parámetros con los que se entendía la vida familiar, estos cambios afectan a toda la estructura familiar, para poder entender estos cambios nos basamos en el conocimiento y perspectiva histórica conocida, la familia conyugal como tal ha sido siempre la más común, surgiendo fundada en lo biológico, para abrigar a madre e hijo, surge en todas las culturas de una pareja heterosexual de adultos y con fines de procreación, la pervivencia de la especie humana ha requerido la protección de la maternidad y después la paternidad, lo que llevó a la convivencia de la pareja, este modelo desde su perspectiva más nuclear y extendida alrededor de dicho núcleo es el que mantienen la práctica totalidad de los países.

El concepto de familia implica aspectos biológicos, sociales y jurídicos, variando de una cultura a otra y aún dentro de la misma se dan subculturas como la urbana o la rural.

En el cambio y la transformación de la institución familiar son muchos los acontecimientos imbricados y relacionados entre sí como son la industrialización, urbanización, expansión y obligatoriedad de la enseñanza, bajada de la natalidad, nuevos sistemas tecnológicos (televisión, vídeos, ordenadores, videojuegos, chat, etc.) los que han contribuido a la transformación de la familia extensa tradicional y han ocasionado el surgimiento de la familia nuclear, provocando un vuelco en el significado que tienen los hijos, en el interés público y privado que expresan, en el concepto de infancia, etc. Como culminación de todo ello, el papel y la función educativa de madres y padres ha sufrido una auténtica revolución. Veamos algunos de estos cambios.

En primer lugar, cobra relevancia la pareja como tal coexistiendo con la pérdida de importancia del matrimonio como institución. Al mismo tiempo, la creciente valoración de los hijos es paralela a la reducción de su número.

En un periodo de tan solo varias generaciones, se ha producido una metamorfosis profunda tanto en la concepción de las necesidades de la infancia, como en las condiciones de vida familiar que experimentan los niños de la denominada "sociedad del bienestar". Los hijos son mucho más importantes que en el pasado. Se tarda más en tener hijos y estos suelen ser consecuencia de una decisión voluntaria. Antes de tener hijos se diseña una preparación cuidadosa para asumir la paternidad, pero, paradójicamente, cada vez se tienen menos hijos. Esta es sin duda una de las características más significativas de las familias actuales.

En segundo lugar, los hijos han pasado de ser algo social y colectivo, a través de los cuales los padres cumplen con una obligación con la sociedad, a ser algo propio y privado, fruto de un objetivo fundamental de su vida, del proyecto de felicidad compartida de la pareja. En otros términos, los hijos se tienen porque se desean y han perdido el carácter de seguro de vida para sus padres. Ahora se espera disfrutar de ellos. Pero, al mismo tiempo, supone mayores responsabilidades que nunca, aumentando sus obligaciones y a la vez se van ensanchando los derechos de los hijos, sobre todo, en lo relativo a una mayor educación y una menor disciplina.

Ello explica también la idea que se tiene de fracaso cuando una pareja que tiene hijos se separa, aunque sea de común acuerdo. La llegada del hijo supone una proyección afectiva importante, el matrimonio se refleja en el hijo y se espera que los lazos afectivos se refuercen con su llegada.

Sin embargo, esto no siempre es así ya que la llegada del hijo implica mayores exigencias de atención, más trabajo, produce gastos económicos y requiere decisiones y, en estos aspectos, es posible que aumenten también los conflictos de la pareja. 
En tercer lugar, se está dando un cambio en las relaciones internas de la familia entre padres e hijos, cada vez más marcadas por la afectividad y los sentimientos en detrimento de otros principios tradicionalmente valorados como el respeto y la obediencia. De este modo, el afecto y la cercanía emocional aparecen como las cualidades que deben presidir las relaciones entre padres e hijos. Ahora entre las obligaciones de los padres no están sólo las de cuidar, alimentar y educar a sus hijos, sino también las de quererlos y asegurarse de su bienestar afectivo y psicológico. Es decir, ahora cada vez más los padres son responsables del equilibrio emocional de sus hijos, de sus orientaciones, problemas o traumas. En estos aspectos, es donde mayor inseguridad manifiestan los padres a la hora de afrontarlos. La relación de los hijos con el padre y la madre está en ambos marcada por la primacía del bienestar del niño y por el temor a contravenirle, a no estar a la altura de sus necesidades. Por ello, es frecuente encontrar una ansiedad frecuente acerca de lo acertado o equivocado de sus orientaciones vitales. De ahí que la angustia y preocupación acerca de la educación de los hijos nunca fue tan fuerte como en la actualidad. Los padres no es mucho lo que pueden decidir pero se le va a responsabilizar de casi todo lo que les pueda suceder a sus hijos. Nunca ha sido tan fuerte la presión sobre los padres ni nunca se han aplicado tan racionalmente al cuidado de la salud, la educación y la estabilidad emocional de los hijos (Alberdi, 1999).

En cuarto lugar, ha cambiado la forma de afrontar el proceso de socialización que se inicia dentro del contexto familiar. Ahora se puede afirmar que existen nuevas formas de socialización. Todos los aspectos de la vida diaria en las sociedades occidentales se modifican cada vez más rápidamente. Las cosas se suceden con una velocidad inusitada. Este dinamismo y aceleración social, mayor que en cualquier otra época histórica, está dejando obsoleto el modelo tradicional de socialización que se inicia en la familia y continúa en la escuela y en ámbito social.

\section{Bibliografía / References}

1. ACTAS do X Congresso Internacional Galego-Portugu s de Psicopedagogia. Braga: Universidade do Minho, 2009. ISBN-978-972-8746-71-1.

2. Barroso M. La experiencia de ser familia. Caracas, Editorial Pomaire. 1995.

3. Fernández A. «¿Cómo promover la interrelación de la escuela, la familia y la comunidad desde la diversidad educativa?» Congreso Internacional Pedagogía 2007. Curso 39. La Habana, 2007.

4. Otero L. Desintegración Familiar. Editorial Culbimex. 1965.

5. URL: http://www.innatia.com/s/c-organizacion-familiar/a-concepto-familia-moderna.html.

6. URL: http://www.monografias.com/trabajos94/disciplina-social-su-contribucion-formacion-ciudadana-del-adolescente/disciplina-social-su-contribucion-formacion-ciudadanadel-adolescente.shtml\#ixzz2btNz2PYZ.

\section{REFERENCE TO ARTICLE}

Maribel Santiesteban Pérez \& Roger David Desten Santiesteban (2018) Structural Changes in the Current Family. Reflexive Compendium, Contemporary Problems of Social Work. Vol. 4. No. 4 (16). P. 84-86. DOI: 10.17922/2412-5466-2018-4-4-84-86 (International bibliographic description).

\section{CONTACT INFORMATION:}

Maribel Santiesteban Pérez

Dr. C., Profesora Titular, Asesora del rector

Universidad de Guantánamo, Guantánamo, Cuba

E-mail: santi@cug.co.cu

Roger David Desten Santiesteban

Profesor Instructor; Especialista en Informática

Empresa Nacional de desarrollo de Software (DESOFT),

Universidad de Guantánamo, Guantánamo, Cuba

E-mail: roger@gtm.desoft.cu 


\title{
Rafael Jorge Hechavarria,
}

M. Sc., Prof. Auxiliar, Universidad de Guantánamo, Cuba.

E-mail:santi@cug.co.cu

\section{Jesús Piclín Minot,}

Dr. C., Prof. Auxiliar, Universidad de Guantánamo, Cuba.

E-mail:jesusp@cug.co.cu

\section{Elena Bailey Agramonte,}

M. Sc., Prof. Auxiliar, Universidad de Guantánamo, Cuba.

E-mail:santi@cug.co.cu

\section{PROCEDIMIENTOS PARA FAVORECER LA IDENTIDAD CULTURAL LOCAL EN EL CONTEXTO DE LA FORMACIÓN DEL PROFESOR DE GEOGRAFÍA}

\author{
Procedures to Promote Local Cultural Identity in the Context of the \\ Geography Teacher Training
}

\author{
Receiving date: \\ Preprint date: \\ 04.09.2018 \\ 19.11.2018 \\ Taking to print date: \\ 18.12.2018
}

Resumen: La formación de la identidad cultural local se dinamiza a partir de las propias necesidades socioeducativas de la sociedad que tienen expresión concreta en el Modelo de Formación del profesional de Geografía. Desde la presente investigación se ofrece una contribución teórico-práctica a la formación de la identidad cultural local en el contexto pedagógico, por lo que se ofrece un sistema de procedimientos que orienten en la apropiación del objeto geográfico como objeto geográfico de identidad local y se asuma como parte de la formación de la identidad cultural local desde la óptica de análisis, de ahí su novedad y pertinencia en la enseñanza de la Geografía.

Annotation: the formation of the local cultural identity is dynamized from the socio-educational needs of society that have concrete expression in the Training Model of the Geography professional. From the present investigation a theoretical-practical contribution to the formation of the local cultural identity in the pedagogical context is offered, for which a system of procedures is offered that guide in the appropriation of the geographical object as an object of local identity and it is assumed as part of the formation of local cultural identity from the perspective of analysis, hence its novelty and relevance in the teaching of Geography.

Palabras clave: formación, identidad cultural local, objeto geográfico de identidad local.

Key words: formation, local cultural identity, geographic object of local identity.

JEL classification: I200, I290.

\section{Introducción}

La formación del profesor de Geografía debe propiciar la apropiación de aquellos contenidos geográficos que por su potencialidad educativa favorezca la formación de la identidad cultural local, de modo que el estudiante en formación en su actuación logre no solo apreciar la belleza 
del paisaje natural sino también revelar los rasgos que le distinguen y permiten que se le ofrezca significatividad.

En el plano internacional son evidentes los presupuestos que asumen los intelectuales sobre el tema de estudio, tal es el caso de A. Moreno (1998), E. Rodríguez (2006), al considerar que es preciso introducir aires renovadores en la formación del profesor de Geografía que les permita comprender las relaciones que se manifiestan en el espacio geográfico, al hacer una Geografía más explicativa, donde los conocimientos no aparezcan fragmentados, aislados entre sí y sin conexión con la realidad.

En el contexto cubano se destacan un grupo de autores como P. Recio (2009), C. Pérez (2008, R. Cuétara (2008, 2015), A. Hernández (2012), E. Rodríguez (2013), P. Álvarez (2014, 2015), J. Mateo (2015), A. Güidi (2017) y G. Guibert (2018), los cuáles realizan desde diversas perspectivas un análisis epistemológico de la formación del profesional de Geografía.

Al respecto se destaca las investigaciones de C. Pérez (2008), R. Cuétara (2008), R. Ernández (2008) y E. Rodríguez (2013) y J. Mateo (2015) al reconocer la función cultural que asume la Geografía, así como su contribución a la formación identitaria en los estudios locales.

Sin embargo, se considera que las investigaciones precedentes dejan carencias teóricoprácticas que no permiten explicar la identidad cultural local en la formación del profesor de Geografía, al no considerar desde el punto de vista pedagógico-geográfico la integración del saber geográfico con el histórico local con fines identitarios, a partir de la preparación en el desarrollo de una educación geográfica que como intencionalidad posibilite la comprensión e interpretación del espacio geográfico local con un sentido de identidad. De ahí que se ofrezca un sistema de procedimientos que orienten en dichos fines como parte de la formación identitaria cultural del profesor de Geografía.

\section{Desarrollo}

Con el desarrollo y transformaciones que experimenta la sociedad contemporánea, la formación del profesional se convierte en un elemento imprescindible en la búsqueda de un profesor cada día más competente, en condiciones de dar respuesta a las demandas de la sociedad. En este sentido la categoría formación ha sido abordada por autores como Bozhovich (1975), B. Honore (1980), C. Álvarez (1994), J. Chávez (1996), E. Baxter (2002), J. López (2005), P. Horrutinier (2007), R. Bermúdez, (2014) y L. Pérez, (2014), A. Alejandro (12),F. Addine (2013), G. Guibert (2018) entre otros.

En el marco conceptual de la Pedagogía cubana autores como C. Zayas (1994) y P. Horrutinier (2007), ofrecen sus consideraciones: “[...] la formación es el proceso y el resultado cuya función es preparar al hombre en todos los aspectos de su personalidad [...]"1. Por otra parte: "se emplea para caracterizar el proceso sustantivo desarrollado en las universidades con el objetivo de preparar integralmente al estudiante en una determinada carrera universitaria y abarca, tanto los estudios de pregrado (o de grado, como se le denomina en algunos países) como los de posgrado"2.

El profesor de Geografía que se forma en la universidad se prepara como profesional para desempeñar con calidad sus funciones y tareas a partir de su objeto social. De ahí que el proceso de formación del profesional de la educación se caracterice como: “[...] la dirección por profesores y maestros de la formación profesional del estudiante, en la que se produce el tránsito hacia niveles superiores de desarrollo en los modos de pensar, sentir y en la calidad de los desempeños para la transformación del contexto de actuación pedagógica y la autotransformación. Es un proceso especializado y sistematizado de educación profesional de la personalidad que tiene en su centro al sujeto que se prepara para ejercerla en un contexto específico de actuación profesional $[\ldots]^{\prime \prime 3}$.

Álvarez de Zayas. La escuela en la vida. La Habana, Cuba: Editorial Pueblo y Educación, 1999. P. 16.

2 Horruitiner, P. La universidad cubana: El Modelo de formación. Revista Pedagogía Universitaria, 2007. P. 13.

3 Parra (2002), citado por Castro, N. Tesis de doctorado. La heurística en la formación del profesional de la Educación secundaria Básica. Holguín, 2010. 
Por lo que se entiende que la formación del profesor de Geografía en el contexto pedagógico es un proceso sistemático y continuo que contribuye a la preparación integral del profesor en formación, así como su identidad hacia la profesión a partir de la adquisición de saberes, habilidades y valores, que le permitan asumir una actuación profesional pedagógica en la búsqueda de respuestas a los problemas que se le plantean en su desempeño y a las exigencias socioeducativas que emanan de la sociedad.

Por otra parte se reconocen los aportes que en el orden epistemológico se ofrecen de la identidad cultural local en la formación del profesional. El cubano R. Zamora (1996), C. Baeza ( 1996), M. García (1996), R. Pupo (2006), C. Córdova (2006), E. Guerra (2015). Se concuerda con C. Baeza (1996) y M. García (1996) al considerar que la identidad cultural local es la producción de respuestas y valores que, como heredero y trasmisor, actor y autor de su cultura, éste realiza en un contexto histórico dado como consecuencia del principio sociopsicológico de diferenciaciónidentificación en relación con otro(s) grupo(s) o sujeto(s) culturalmente definido (s) ${ }^{1}$.

Estos autores analizan el proceso identitario y sus relaciones con la cultura, donde el sujeto de la cultura en la comunicación con otros significativos, a través de la actividad identitaria, es capaz de decodificar, codificar y transformar los mensajes culturales que recibe y responder a ellos, que a partir de su diferenciación respecto al otro significativo e identificación con el mismo, deviene en su actuación sujeto de identidad.

Además tienen en cuenta la continuidad histórica del proceso identitario, al demostrar la vigencia en el tiempo de los objetos de identidad de acuerdo a su funcionalidad cultural y estos objetos de identidad cuando pierden su intención comunicativa pasan a formar parte de la memoria histórico-cultural y son potencialmente utilizables por el sujeto de la cultura en ulteriores proceso identitarios.

Esta visión integral de la identidad cultural local, contribuye a ver patrones culturales en la Geografía que permiten revelar su función cultural y de identidad local, el geógrafo R. Cuétara (1998) advierte: “Constituye una verdad conocida en nuestro quehacer profesional, que la literatura geográfica ha dedicado más espacio a teorizar sobre el contenido, que a las vías por las cuales el escolar se apropia del conocimiento en la realidad circundante, habida cuenta de que ese entorno constituye, en sí mismo, la geografía del lugar que habitamos"2.

Se concuerda con Mateo (2015) al plantear que el espacio geográfico es el soporte de unos sistemas de relaciones, donde unas se determinan a partir de los elementos del medio físico y otras procedentes de las sociedades humanas que ordenan el espacio en función de la densidad del poblamiento, de la organización social y económica, del nivel de las técnicas, de los significados que tiene para la sociedad; en una palabra todo el tejido histórico que constituye una civilización.

La comprensión del espacio geográfico permite conocer, comparar y contrastar los objetos, procesos, fenómenos y hechos que ocurren en cada lugar, en el contexto pedagógico, el estudiante al explorar, recopilar y analizar la información espacial para diferenciar los lugares en diferentes escalas (local, regional, nacional, y global), configura su propia cultura, que en el escenario educativo de la Geografía, es la cultura geográfica lo que le lleva a conclusiones previas y tomar decisiones. Así la Geografía es parte de la cultura e identidad del sujeto, "cultura que está articulada a espacios concretos de realización de los individuos, de los grupos sociales y de las sociedades" afectividad, son soporte de la identidad; o sea, de la cultura interiorizada por los individuos aislados y en colectividad"4.

${ }^{1}$ Baeza, C. y García, M. Modelo teórico de identidad cultural local. Centro de Investigación y Desarrollo de la Cultura Cubana "Juan Marinello", 1996. P. 17.

2 Cuétara R. Tesis de doctorado. Una propuesta teórico-metodológica para el estudio de la localidad en la enseñanza de la Geografía escolar. ISP Enrique José Varona, 1998. P. 6.

${ }^{3}$ Pérez, C., Cuétara R. y Alfonso, I. Cultura, identidad nacional y geografía. Revista Varona, 2008. No. 46. P. 50.

${ }^{4}$ Ibídem. 
De esta manera, el espacio geográfico atesora objetos naturales que por sus características, comprensión y apropiación por el sujeto de la cultura, posibilita o no, la formación de la identidad cultural local. Lo anterior, demanda un profesor de Geografía preparado y capaz de poner al estudiante en un estadío donde sea capaz de interpretar el objeto geográfico de identidad local como una formación natural o socioeconómica, donde su singularidad geográfica e histórica asociada, posibilita que el sujeto le atribuya significación y valor identitario al hacerlo parte de su identidad cultural local. Lo que permite que se manifieste como sujeto de identidad, el cual es un "sujeto de la cultura que en el proceso de comunicación con otro significativo se ha diferenciado de este y por ello ha reconocido, consciente o inconsciente pero siempre como sujeto actuante, su identidad cultural"1.

Los aspectos antes sistematizados han posibilitado organizar y estructurar un sistema de procedimientos para favorecer la formación de la identidad cultural local desde la apropiación del objeto geográfico local como un objeto geográfico de identidad local. A continuación se presentan los procedimientos con sus respectivas acciones metodológicas:

\section{Identificar los objetos geográficos locales de significación cultural identitaria.}

Acciones metodológicas asociadas al procedimiento:

- Análisis de la cultura del contexto geográfico local.

Todo contexto geográfico adquiere características que desde el punto de vista cultural le son inherentes en la construcción de una identidad local que identifica al sujeto de la cultura y lo hace diferente de otras culturas que caracteriza a determinados contextos geográficos, a diversas escalas sea local, regional o global. De ahí, que las relaciones que se establecen entre los sujetos de la cultura y de los sujetos de la cultura con los objetos naturales, hacen del contexto geográfico local un sistema vivo, que se enriquece con la producción cultural y la manera con que los objetos geográficos y las creaciones tienen sentido de pertenencia para el sujeto que crea y se recrea dentro de la propia cultura del contexto geográfico local.

Por tanto, es preciso que el profesor de Geografía tenga conocimientos de aquellos elementos de la identidad cultural que tipifican al contexto geográfico local. De modo que el análisis de diversas fuentes de información cultural le permita tener una visión general de la cultura que se ha generado (construido) como parte de la tradición y la memoria histórica.

- Identificación de los rasgos que singularizan a los objetos geográficos locales que lo hacen distintivos de otros objetos geográficos.

El contexto geográfico local, se encuentra representado por una serie de objetos, procesos y fenómenos geográficos que por sus características que le singularizan enriquecen la cultura y los valores espirituales (identidad) de los sujetos y del territorio en general. Es por ello que el profesor en la búsqueda de información cultural debe propiciar no solo la incorporación de esta sino también la comparación, para que sea capaz de reafirmar la singularidad del objeto geográfico desde la comparescencia con otros objetos geográficos, que pueden estar ubicados dentro de los límites del contexto geográfico local o no. Lo que debe conducir a sentir orgullo por el lugar de nacimiento y manifestarse con un sentido de pertenencia por el objeto geográfico y el contexto geográfico en general. La manera que haya sido comprendida e interpretada la singularidad del objeto geográfico, condiciona lo afectivo-motivacional del sujeto de la cultura, y así devendrá significatividad cultural identitaria.

2. Determinar la significación histórica asociada al objeto geográfico identificado.

- Identificar los hechos históricos locales asociados al objeto geográfico de significación cultural identitaria. Desde el enfoque geohistórico el análisis del contexto geográfico local conduce en primer término a revelar los hechos históricos ocurridos y en segundo lugar identificar cuáles de estos están asociados al objeto geográfico de significación cultural identitaria. De este modo, el profesor evaluará el nivel de singularidad del hecho histórico local que asociado

García, M. y Baeza, C. Modelo teórico para la identidad cultural local. Centro de Investigación y desarrollo de la Cultura Cubana "Juan Marinello", 1996. P. 25. 
al objeto geográfico posibilita afianzar el sentido de pertenencia por el lugar y para ello se auxiliará de materiales de contenido histórico local, e incluso la visita a instituciones culturales que enriquecen dicha información.

- Análisis de la relación espacio-temporal que se establece entre el hecho historic local identificado y el objeto geográfico de significación cultural identitaria.

Tiempo y espacio, son dos categorías que desde el punto de vista metodológico orientan en la comprensión de la dinámica del contexto geográfico local, y en específico la relación que se establece entre el hecho histórico ocurrido en un tiempo determinado y el espacio geográfico que este ocupa, e incluso en ocasiones confluyen en un mismo espacio geográfico el hecho histórico local y el objeto geográfico local. Por otra parte, la dinámica espacio-temporal posibilita valorar con sentido crítico-interpretativo el vínculo hecho histórico-objeto geográfico desde el comportamiento de ambos elementos a partir del estudio pasado-presente, en la búsqueda de nexos que permitan fundamentar la significación histórica del objeto geográfico y conservar para futuro los valores autóctonos de identidad cultural local.

\section{Reconstrucción de la representación geohistórica del objeto geográfico de} significación geohistórica cultural identitaria.

- Concretar el estudio teórico realizado para la reconstrucción de la representación geohistórica del objeto geográfico de significación geohistórica cultural identitaria.

La representación geohistórica del objeto geográfico posibilita la concreción del estudio teórico realizado con anterioridad, donde el profesor de Geografía al revelar la singularidad del objeto geográfico y su significación histórica, posibilita la comprensión e interpretación del objeto geográfico como objeto geográfico de significación geohistórica cultural identitaria, por lo que ha representado para la cultura del contexto geográfico local a partir de las propias significaciones atribuidas por los sujetos de la cultura. Lo anterior significa que el objeto geográfico a adquirido ciertas cualidades culturales identitarias que hacen de él un objeto de identidad local, que condiciona la actuación y el discurso, al posibilitar manifestarse con arraigo y sentido de pertenencia por el contexto geográfico local. Por otra parte, el empleo de materiales cartográficos contribuye a la ubicación y localización del objeto geográfico en su representación geohistórica, por lo que se debe hacer confluir mapas geográficos e históricos de la localidad, así como otros materiales que permitan a través de la observación y el análisis, representar al objeto geográfico desde el enfoque geohistórico.

4. Incorporar al contenido geográfico el objeto geográfico de significación geohistórica cultural identitaria como objeto de identidad.

- Asumir una posición teórico-metodológica de la conceptualización del objeto geográfico como objeto de identidad.

El estudio de la realidad geográfica local como el escenario contextual donde confluyen los objetos geográficos de significación cultural identitaria y su significación histórica asociada, así como la manera de hacer suyos el sujeto de la cultura estos elementos posibilita comprender a este objeto geográfico como objeto de identidad de significación geohistórica cultural identitaria. El propio sujeto de la cultura, a partir de las significaciones cultural identitarias que le atribuye, le ofrece un estatus socio-cultural entre los sujetos de la cultura que hacen del objeto geográfico de identidad un símbolo. Identificar las potencialidades educativas del contenido geográfico para la integración e interacción del objeto geográfico de significación geohistórica cultural identitaria como objeto de identidad en el contenido geográfico.

De esta manera, corresponde al profesor de Geografía la incorporación al contenido geográfico del objeto geográfico de significación geohistórica cultural identitaria, para ello debe tener en cuenta las potencialidades educativas del contenido geográfico, son estas las que posibilitan dicho procedimiento, pues la integración e interacción del objeto geográfico en el contenido geográfico no puede manifestarse de manera forzada sino más bien aprovechar las propias potencialidades que ofrece el sistema de conocimientos, las habilidades y los valores 
a potenciar. Por tanto la integración e interacción del objeto geográfico local en el contenido estará determinada por la cohesión, coherencia y la adecuación, lo que posibilita su correcta contextualización.

\section{Apropiación del objeto geográfico local contextualizado en el contenido de enseñanza como objeto geográfico de identidad local.}

- Concretar los rasgos distintivos del objeto geográfico contextualizado en el contenido de enseñanza devenido objeto geográfico de identidad local.

La apropiación del objeto geográfico local parte de entender que es un proceso individual, donde la experiencia histórico-cultural se enriquece a partir de incorporar nuevos conocimientos a su aprendizaje, donde el maestro actúa como mediador cultural entre el sujeto de la cultura (el profesor en formación) y el objeto geográfico local (contextualizado en el contenido de enseñanza). Para lograr la apropiación es preciso que se garantice una adecuada comprensión e interpretación socio cultural del contenido de enseñanza. Todo ello implica, el desarrollo de los procesos cognoscitivos y afectivo-motivacional, lo que conforma y da sentido personal desde la significación geohistórica cultural identitaria que se le ofrece como cualidad transferida al objeto geográfico.

De esta manera, la apropiación del objeto geográfico de identidad local transcurre por los procedimientos antes descritos que actúan como niveles, lo que posibilita el tránsito de un estadío inferior a uno superior. Por tanto la interiorización del objeto geográfico de identidad local conduce a una actuación y comunicación que sea expresión del autorreconocimiento y la pertenencia por lo que para él significa no solo el objeto geográfico de identidad sino el contexto geográfico local en general.

\section{Conclusiones}

La formación de la identidad cultural local en el contexto de la formación inicial del profesor de Geografía constituye un reto para docentes y estudiantes a partir de garantizar dicho proceso desde la apropiación del objeto geográfico de identidad local en la enseñanza de la Geografía. Es por ello que los procedimientos propuestos son una aproximación al problema planteado y se orientan hacia lograr un profesor de Geografía más competente y comprometido con su contexto geográfico local.

\section{Bibliografía / References}

1. Áddine Fernández, F. (1998) (en soporte digital). Didáctica y optimización del proceso de enseñanza - aprendizaje.

2. Álvarez, Pedro, Esther Celina y Recio Pedro (2015). La formación del profesor de Geografía en Cuba ante la pluralidad de enfoques epistemológicos de la ciencia geográfica: retos y perspectivas actuales. Universidad Pedagógica "Enrique José Varona", Revista Varona núm. 61, Julio - diciembre, p. 1-17.

3. Baeza, C. (1996) Modelo teórico para la identidad cultural. Edit. José Martí, La Habana.

4. Batista Rodríguez, A. (2001) Propuesta pedagógica para el trabajo con los valores dignidad e identidad nacional en el ISPH. Tesis en opción al título académico de Master. UCP “José de La Luz y Caballero", Holguín.

5. Córdova, C. Axiología e Identidad (2008) Centro de Estudios de Cultura e Identidad. Universidad "Oscar Lucero Moya" de Holguín. (Documento en soporte digital).

6. Cuétara López R. (2004) Hacia una Didáctica de la Geografía local. Editorial Pueblo y Educación, La Habana.

7. García Alonso, M. (2002) Identidad e Investigación. Centro de Investigación y Desarrollo de la Cultura Cubana Juan Marinello. La Habana.

8. Guibert Rodríguez, G. (2018) Concepción metodológica para el establecimiento de relaciones entre la Geografía de Cuba y la Historia de Cuba. Tesis en opción al grado científico Doctor en Ciencias Pedagógicas. UCP “Enrique José Varona”, La Habana.

9. Mateo Rodríguez, J. (2015) Teoría y Metodología de la Geografía. Editorial Universitaria: Félix Varela, La Habana.

10. Pérez Álvarez, C. (2002) Didáctica de la Geografía. Selección de temas. Editorial Pueblo y Educación, La Habana 
11. Pupo, R. (2006) El hombre, la actividad humana, la cultura y sus mediaciones fundamentales. Tesis en opción al grado académico de Doctor en Ciencias. Universidad de La Habana.

12. Tovar, R. (1995) Boletín Geohistórico N 1. Centro de Investigaciones Geodidácticas y de Aplicación Geodidáctica. Caracas.

13. Zamora, R. (1994) Notas para un estudio de la identidad cultural cubana. Centro de Estudio de la Cultura Cubana. La Habana.

\section{REFERENCE TO ARTICLE}

Rafael Jorge Hechavarria, Jesús Piclín Minot \& Elena Bailey Agramonte (2018) Procedures to Promote Local Cultural Identity in the Context of the Geography Teacher Training, Contemporary Problems of Social Work. Vol. 4. No. 4 (16). P. 87-93. D0I: 10.17922/24125466-2018-4-4-87-93 (International bibliographic description).

\section{CONTACT INFORMATION:}

Rafael Jorge Hechavarria

M. Sc., Prof. Auxiliar

Universidad de Guantánamo, Guantánamo, Cuba

E-mail:santi@cug.co.cu

Jesús Piclín Minot

Dr. C., Prof. Auxiliar

Universidad de Guantánamo, Guantánamo, Cuba

E-mail: jesusp@cug.co.cu

Elena Bailey Agramonte

M. Sc., Prof. Auxiliar

Universidad de Guantánamo, Guantánamo, Cuba

E-mail:santi@cug.co.cu 


\title{
Yaritza Martínez Adams,
}

MsC., Profesora Auxiliar, Universidad de Guantánamo, Cuba.

E-mail:santi@cug.co.cu

\section{Gener Chang Jorge,}

Lic., Profesor Auxiliar, Universidad de Guantánamo, Cuba.

E-mail:santi@cug.co.cu

\section{LA INTEGRIDAD BIOLÓGICA DEL ORGANISMO HUMANO EN EL CONTEXTO DE TRABAJO DE CAMPO}

\author{
The Biological Integrity of the Human Organism \\ in the Context of Field Work
}

\author{
Receiving date: \\ Preprint date: \\ 11.09.2018 \\ 19.11.2018 \\ Taking to print date: \\ 18.12.2018
}

Resumen: Las prácticas de campo cumplen una función importante en la formación del futuro profesor de la Licenciatura en Educación Especialidad Biología, al vincular los conocimientos adquiridos en las diferentes disciplinas, a la realidad en que se manifiestan en un ecosistema determinado, ya sea marino, dulceacuícola o terrestre, aplicando los conocimientos a los nuevos escenarios a los que se enfrentan en el transcurso de esta actividad. El carácter particularmente práctico de las actividades a desarrollar hacen que tengan una especial trascendencia para el futuro profesional, ya que le permite aplicar los conocimientos teóricos adquiridos a las nuevas situaciones planteadas en las actividades de prácticas de campo, contribuyendo al desarrollo de habilidades de observación de los componentes, fenómenos y procesos que ocurren en la naturaleza, vinculados con la biodiversidad, en función del desarrollo sostenible mediante el logro de la actividad independiente en el trabajo de campo.

Annotation: the field practices play an important role in the formation of the future teacher of the Bachelor of Education in Biology, by linking the knowledge acquired in the different disciplines, to the reality in which they manifest themselves in a given ecosystem, whether marine, freshwater or terrestrial, applying the knowledge to the new scenarios that they face in the course of this activity. The particularly practical nature of the activities to be carried out makes them of special significance for the professional future, since it allows them to apply the acquired theoretical knowledge to the new situations posed in field practice activities, contributing to the development of observation skills in the field. The components, phenomena and processes that occur in nature, linked to biodiversity, in terms of sustainable development through the achievement of independent activity in field work.

Palabras clave: práctica de campo en la formación del futuro profesor de la Licenciatura en Educación Especialidad Biología; desarrollo de habilidades de observación; aplicación de conocimientos teóricos en actividades prácticas.

Key words: field practice in the training of the future teacher of the Bachelor of Education in Biology; development of observation skills; application of theoretical knowledge in practical activities.

JEL classification: I200, I290.

\section{Introducción}

La integridad de los organismo es una manifestación que se basa sobre el enlace común de los objetos y fenómenos por así decirlo, que tenga capacidad para el auto desarrollo y la auto 
reproducción. Desde el punto de vista dialéctico se dice que es necesario tener la capacidad del todo para el auto control y que existe una estrecha relación entre el organismo y el medio que le rodea. El organismo humano constituye un todo único cuya integridad está asegurada por la asociación de las diferentes estructuras que lo componen. Pudiendo decir que el organismo humano no es una simple suma de sus segmentos, es todo un sistema complicado de relaciones mutuas de elementos y proceso que poseen una cualidad particular que le distingue de otros sistemas.

La propuesta que se presenta obedece a la modalidad de metodología, ya que en ella se ofrece un proceder metodológico ordenado y concatenado que conforma un todo sistémico para el tratamiento a la integridad biológica del organismo humano en el contexto de trabajo de campo, según el diccionario de términos biológicos, se refiere a los conocimientos, principios, teorías y todas las informaciones que sustentan y racionalizan los contenidos biológicos, en la descripción y explicación de este proceso en el mundo natural.

En este sentido, se asume el criterio de los doctores, Nerelys de Armas Ramírez, José M. Perdomo Vázquez y Josefa Lorence González, (2004) del Centro de Estudios de Ciencias Pedagógicas (CECIP) de la Universidad de Ciencias Pedagógicas "Félix Varela y Morales", acerca del significado del término metodología, “...el que se asocia a los aspectos operativos del método científico. Desde una perspectiva operacional, el método es una secuencia de procedimientos que nos permiten conseguir un fin".

\section{Desarrollo}

La metodología constituye, una vía para dirigir el proceso de apropiación por el educando de los contenidos relacionados con la integridad biológica del organismo humano en el contexto de trabajo de campo que le permitirá planificar ,orientar, dirigir y evaluar la realización de actividades en la práctica educativa, lo que significa recurrir a procedimientos metodológicos que de una manera particularmente organizada y concatenada expresen una unidad que permita su consideración como un todo sistémico, como es el caso de la que se propone en la presente investigación.

El objetivo general de la misma es: Contribuir al perfeccionamiento del tratamiento a la integridad biológica del organismo humano en el contexto de trabajo de campo en el proceso de enseñanza aprendizaje de la disciplina Anatomía y Fisiología Humanas, en tanto se centra en el proceder del docente para el logro de este fin. Se compone de dos aparatos estructurales: un aparato teórico o cognitivo y uno metodológico o instrumental.

En el caso particular de la presente investigación el aparato cognitivo de la metodología está integrado por:

Las leyes, principios, categorías, conceptos que fundamentan el tratamiento metodológico a la integridad biológica del organismo humano en el contexto de trabajo de campo en el proceso de enseñanza - aprendizaje de la disciplina Anatomía y Fisiología Humanas.

Las leyes predominantes son las pedagógicas, las que fundamenta el necesario vínculo de la escuela con la vida y la interrelación dialéctica entre los componentes del proceso pedagógico como requisito para la dirección del mismo. Estas son tienen en cuenta para la determinación de los momentos y acciones según pasos lógicos por el docente para perfeccionar el tratamiento metodológico a la integridad biológica del organismo humano en el contexto de trabajo de campo.De estas leyes se derivan un grupo de principios, como aspectos generales de la estructuración organizativa del proceso de enseñanza - aprendizaje.

Su diseño tiene en cuenta el carácter de sistema que lo estipula, así como las relaciones que existentes entre ellos. El objetivo es establecer relaciones entre los conocimientos biológicos en el contexto de trabajo de campo para que los estudiantes logren reflexionar sobre lo que aprenden y cómo se apropian de los conocimientos.

La metodología debe cumplir exigencias particulares que sustentan el proceso de enseñanza -aprendizaje de la disciplina Anatomía y Fisiología Humanas en la carrera Licenciatura en Educación Especialidad Biología, y que se refieren a: 
$\checkmark$ Favorecer la comprensión, explicación de fenómenos y procesos biológicos que ocurren en el organismo humano durante trabajo de campo, conjuntamente con el desarrollo de procesos cognoscitivos y afectivo-motivacionales mediante las relaciones inter-psicológicas e intrapsicológicas, y las potencialidades meta-cognitivas de los educandos;

$\checkmark$ Elaborar situaciones de aprendizaje en correspondencia con las vivencias de los estudiantes que deben revelar, en lo posible, el carácter social de la ciencia;

$\checkmark$ Evidenciar rasgos de la actividad investigadora contemporánea: trabajar en equipo, distribuirse responsabilidades, tomar decisiones, manejar de manera adecuada las dificultades que se presentan, saber cuándo tomar la palabra para opinar, exponer y argumentar en torno a un tema, expresarse con claridad y coherencia;

$\checkmark$ Establecer una comunicación, basada en el respeto mutuo a la individualidad, al grupo y a la ética;

$\checkmark$ Emplear el vocabulario técnico en correspondencia con las exigencias del profesional de carrera Licenciatura Educación Especialidad Biología.

La aplicación de la metodología se concibe a través de una secuencia de etapas que responden al objetivo para el cual se elabora. En cada una de estas se planifica el desarrollo de pasos y, como parte de los mismos, procedimientos que se presentan al explicar cómo se pone en práctica.

Para su determinación se tienen en consideración los siguientes criterios de selección:

$\checkmark$ Preparación didáctico-metodológica para el proceso de enseñanza-aprendizaje de la disciplina Anatomía y Fisiología Humanas;

$\checkmark$ Relación entre el proceso de enseñanza de los conocimientos biológicos y la actividad física.

De acuerdo con los elementos teóricos que se abordan y los criterios asumidos, se determina que las primeras tres etapas de la metodología responden al primer criterio, y la cuarta y la quinta al segundo.

$\checkmark$ Primera etapa. Identificación de las relaciones entre los procesos biológicos a partir de la integración de los diferentes sistemas de órganos teniendo en cuenta su estructura y función a partir de la influencia de la actividad física en el contexto de trabajo de campo.

$\checkmark$ Segunda etapa. Diagnóstico cognitivo-instrumental.

$\checkmark$ Tercera etapa. Planificación de las situaciones de aprendizaje.

$\checkmark$ Cuarta etapa. Introducción y ejecución en la práctica pedagógica.

$\checkmark$ Quinta etapa. Evaluación.

Se impone realizar el análisis de los pasos y los procedimientos que se desarrollan en cada etapa para determinar las formas en que operan y las relaciones que entre estos deben darse, con el propósito de evaluar la calidad y efectividad de la metodología y comprobar la validez de las etapas que se aplicaron, se empleó el método de criterio de especialistas.

La esencia de este método consiste en la organización de un diálogo con los especialistas mediante el instrumento aplicado con vista a obtener un consenso general, o al menos los motivos de las discrepancias.

Se seleccionaron como muestra a 15 especialistas, los que debían reunir las siguientes condiciones: Poseer más de 10 años de graduado, con una vasta experiencia en la Educación Superior, conocer el modelo del profesional de la carrera, tener conocimiento sobre el tema de investigación y disposición para evaluar la factibilidad de la metodología propuesta.

En este caso se seleccionaron15 especialistas con más de 14 años de experiencia profesional en la Educación Superior, de ellos 1 poseen el Grado Científico de Doctor en Ciencias, 4 el Título académico de Máster en Ciencias y 10 Licenciados, todos con un amplio conocimiento en la temática con categoría de auxiliares.

De las cinco etapas que conforman la metodología, consideramos oportuno no someter a criterio de los especialistas la etapa No. 1 porque esta consta de elementos que constituyen el 
punto de partida para el trabajo con las otras, garantizando la preparación teórico-metodológica de los profesores para que desarrollen el tratamiento metodológico de la integridad biológica del organismo humano en el contexto e trabajo de campo.

Con la aplicación de los instrumentos se constató el nivel de satisfacción de los especialistas referente a las etapas que constituyen la metodología., obteniendo como resultados los siguientes:

Evalúan la segunda etapa de bastante adecuada 9 especialistas que constituyen el $60 \%$ y los 6 restantes para el $40 \%$ de adecuada, al compartir el criterio propuesto relacionado con las vías de fundamentación biológica de la actividad física mediante las potencialidades del contenido y apoyados en el conocimiento de las vivencias personales de los estudiantes.

La tercera etapa es evaluada de bastante adecuada por 7 para un $46,6 \%$ y 8 para el $47 \%$ de adecuada, estando de acuerdo con los procedimientos para la evaluación el cumplimiento de los objetivos propuestos.

Varios especialistas ofrecieron sugerencias, proposiciones, recomendaciones e ideas que se tomaron en cuenta para la conformación definitiva de la propuesta.

De forma general, la metodología propuesta es calificada de adecuada por 9 especialistas que representan el $60 \%$ y 7 para el $40 \%$ la evalúan de bastante adecuada, por lo que considerando la pertinencia de los especialistas, podemos concluir en la aprobación de la misma para la fundamentación biológica de la actividad física en los estudiantes del segundo año de la Licenciatura en Educación Especialidad Biología en la Facultad de Educación.

Los profesores consideran importante la propuesta de las etapas, máxime cuando se trata los conocimientos relacionados con la integridad biológica del organismo humano en el contexto de trabajo de campo y su aplicación en la actividad profesional del egresado de la carrera.

Los especialistas ofrecieron algunas sugerencias y críticas que fueron asumidas y contribuyeron al perfeccionamiento del sistema propuesto. Esto explica el hecho de que exista un consenso general en la evaluación del mismo como adecuado.

\section{Conclusiones}

La metodología diseñada, se puede utilizar en las diferentes asignaturas de la disciplina Ciencias Biológicas de la carrera Licenciatura en Educación Especialidad Biología para tributar a la formación del modelo del profesional, abandonando posiciones tradicionales, promoviendo la actitud hacia el cambio.

Se recomienda en la concepción de las formas de organización de la docencia, los talleres, clases prácticas y los seminarios integradores que constituyen el aspecto más significativo de los objetivos de la misma con respecto a la conformación del modo de actuar del futuro profesional.

\section{Bibliografía / References}

1. Addine Fernández, Fátima. Aproximación y sistematización de los contenidos didácticos y sus relaciones. Informe de investigación. Facultad de Ciencias de la Educación. ISP “Enrique José Varona" Ciudad de La Habana, 1998.

2. Almirall Borrego, Julio (1999) Diseño de la disciplina principal integradora de la carrera de Licenciatura en Cultura Física. Tesis en opción al grado científico de Máster en Ciencias de la Educación Superior. Santiago de Cuba: Centro de Estudio F. Gran.

3. Addine Fernández, Fátima y García Batista, Gilberto. Didáctica: Teoría y práctica. Compilación. Compendio de Pedagogía. Ciudad de la Habana: Editorial Pueblo y Educación. Cuba, 2004.

4. Álvarez Aguilar, Nivia y Otros. (2000) La educación en valores del estudiante universitario a través del proceso docente educativo. Curso 8: Universidad 2000. La Habana.

5. Álvarez De Zayas, Rita Marina (1997) Hacia un currículo integral y contextualizado. Editorial Academia. La Habana.

6. Amador, Amelia (1998) Algunas reflexiones sobre la educación en valores. Material inédito. Instituto Central de Ciencias Pedagógicas. La Habana. 
7. Arés Muzio, Patricia (1998) Familia, ética y valores en la realidad cubana actual. p. 57-64. En Temas. No.15. La Habana, julio - sep.

8. Barrios Recio, Joaquín (1995) Consideraciones de las características psicomotrices de las edades en Manual para el deporte de iniciación y desarrollo. Venezuela: Gráfico Reus.

9. Barrios, José María (1997) Democracia real versus democracia formal. Breve reflexión sobre la urgencia de una educación en valores. Universidad Complutense de Madrid.

10. Bermúdez Morris, Raquel y Martín, Lorenzo (1996) Modelo Integral Educativo para el Crecimiento Personal (MEICREP). CEPROF. ISPETP. La Habana.

11. Bermúdez Sarguera, Rogelio y Rodríguez Rebustillo, Marisela (1996) Teoría y metodología del aprendizaje. Editorial Pueblo y Educación. La Habana.

12. Blanco, Juan A. (1998) Ética y civilización: apuntes para el tercer milenio. P. 39-46. En Temas. No. 15. La Habana, jul. - sep.

13. Pedagogía Problémica: acerca de los nuevos paradigmas en educación. Editorial TM. Convenio Andrés Bello. Colombia.

14. Camino Trapen, María (1999) Valores que priorizan los docentes en su actuación pedagógica y como son percibidos por sus alumnos. Colombia. Tesis en opción del grado de Máster.

15. Castro Ruz, Fidel (1986) Ideología, conciencia y trabajo político. La Habana: Editora. Política.

16. Cohen, Rubén (2002) Agresión y violencia en el deporte. URL: http://www.efdeportes.com. htm consulta: 2 de junio 2003.

17. Chacón Arteaga, Nancy (1999) Formación de valores morales. Editorial Academia. La Habana. Cuba. 53p.

18. Enciclopedia Microsoft Encarta (2009) Edición multimedia. Cía Microsoft. USA.

19. Fernández Nancy (2003) Epistemología, metodología y estudios de comunicación social. http://www.ncfernal.com. htm consulta: 2 de junio 2003.

20. Fuentes González, Homero y Álvarez Valiente, Ilsa (1998) Dinámica del proceso docente educativo de la educación superior. CEES "Manuel F. Gran". Universidad de Oriente. Santiago de Cuba.

21. Gómez Gutiérrez, Luis (2001) Conferencia Especial. El desarrollo de la Educación en Cuba Pedagogía 2001. Ciudad de la Habana.

22. Habernas J. (1989) Teoría de la Acción Comunicativa: Complementos y estudios previos. Madrid. Cátedra. P. 479-507.

23. Konnikova T.E. (1975) Metodología de la labor educativa. México: Editorial Grijalbo.

24. Kohlberg, Lawrence (1992) Psicología del desarrollo moral. Biblioteca Desclée de Brouwer. Bilbao.

25. Kraftchenko Beato, Oksana y González Maura, Viviana (2002) Una propuesta teórico metodológica para el estudio y formación de valores desde el enfoque histórico - cultural de L.S. Vigotski. Evento Universidad 2002. La Habana.

26. Laurencio Leyva, Amauris (2002) La historia local y su proyección axiológica - identitaria en el proceso de enseñanza de la Historia de Cuba en Secundaria Básica. Tesis de doctorado. ISPH.

27. López Hurtado, Josefina (1997) Vigencia de las ideas de L. S. Vigotsky. Curso pre - evento. Pedagogía 97. La Habana.

28. Macedo, Donaldo (1994) La naturaleza política de la educación. Entrevista a Paulo Freire. Editorial Planeta. S.A. Barcelona.

29. Martínez Pérez, Nurima (2004) Historia del Voleibol en Guantánamo. Registro de propiedad intelectual.

30. Matveev, l. (1983) Fundamentos del entrenamiento deportivo. Moscú: Editorial Raduga.

31. Machado Rodríguez, Darío L. (2000) Opinión pública, medios de comunicación e identidad Cultural. Revista Cuba Socialista No. 17. La Habana.

32. Mirabal Borrego, Julio 0. (1999) Diseño de la disciplina principal integradora de la carrera de Licenciatura en Cultura Física. Tesis en opción al grado científico de Master en Ciencias de la Educación Superior. Santiago de Cuba: Centro de Estudio F. Gran.

33. Morales Basadre, Ricardo (2000) El mundo en busca de valores. Revista Educación 32. Lima, Perú.

34. Muñoz Sedano, Antonio (1999) Valores y actitudes. Revista Acción Educativa. P. 25-28. Universidad Complutense. Madrid.

35. Noa Cuadro, Héctor (2003) Estudio sobre la selección de talentos futbolísticos para la iniciación al deporte de alto rendimiento. Tesis en opción al Grado Científico de Doctor en Ciencias. Universidad de las Palmas de Gran Canarias. 
36. Nocedo Lero, Irma (2000) La formación de valores en la educación superior desde un enfoque psicopedagógico: AECES.

37. Ojalvo Mitrani, Victoria (2000) Competencia comunicativa y educación de los valores en estudiantes universitarios. La Habana Universidad. 72. Ojalvo, V. Y otros (1999) Concepción de la enseñanza aprendizaje y organización docente para la formación de valores en estudiantes universitarios, Informe de investigación, CEPES; UH.

38. Ortiz Ocaña, Alexander L. (2002) Metodología para la enseñanza problémica de la Contabilidad en la Educación Técnica y Profesional. Tesis de Doctorado. ISP "José de la Luz y Caballero". Holguín. ORGANIZACIÓN MUNDIAL DE LA SALUD OMS. (2015). Estrategia mundial sobre régimen alimentario, actividad física y salud. 10 de abril de 2015.

\section{REFERENCE TO ARTICLE}

Yaritza Martínez Adams \& Gener Chang Jorge (2018) The Biological Integrity of the Human Organism in the Context of Field Work, Contemporary Problems of Social Work. Vol. 4. No. 4 (16). P. 94-99. DOI: 10.17922/2412-5466-2018-4-4-94-99 (International bibliographic description).

\section{CONTACT INFORMATION:}

Yaritza Martínez Adams

MsC., Profesora Auxiliar

Universidad de Guantánamo, Guantánamo, Cuba

E-mail:santi@cug.co.cu

\section{Gener Chang Jorge}

Lic., Profesor Auxiliar

Universidad de Guantánamo, Guantánamo, Cuba

E-mail:santi@cug.co.cu 
The certificate of registration of mass media in the Federal service on supervision of legislation observance in sphere of mass communications and cultural heritage protection PE №FS-77-61246 from 03.04.2015.

Sent for the press 18.12 .2018

Demy printing paper 70x100 1/16. Typeface "Magazine". Conventionally printed sheets 12,8

Circulation 2000 exemp.

Publishing house of Russian State Social University. 129226, Moscow, Wilhelm Pieck street, 4, building 2 Phone: 8 (495) 255-67-67, extension line (30-06) www.rgsu.net

Printed by the Russian State Social University. 129226, Moscow, Wilhelm Pieck street, 4, building 2 Phone: 8 (495) 255-67-67, extension line (30-40)

Order № 19-7 